\title{
Polygenic determination of cardiovascular risk : a population study on arterial structure and function
}

Citation for published version (APA):

Balkestein, E. J. M. (2002). Polygenic determination of cardiovascular risk : a population study on arterial structure and function. [Doctoral Thesis, Maastricht University]. Universiteit Maastricht. https://doi.org/10.26481/dis.20020606eb

Document status and date:

Published: 01/01/2002

DOI:

10.26481/dis.20020606eb

Document Version:

Publisher's PDF, also known as Version of record

\section{Please check the document version of this publication:}

- A submitted manuscript is the version of the article upon submission and before peer-review. There can be important differences between the submitted version and the official published version of record.

People interested in the research are advised to contact the author for the final version of the publication, or visit the DOI to the publisher's website.

- The final author version and the galley proof are versions of the publication after peer review.

- The final published version features the final layout of the paper including the volume, issue and page numbers.

Link to publication

\footnotetext{
General rights rights.

- You may freely distribute the URL identifying the publication in the public portal. please follow below link for the End User Agreement:

www.umlib.nl/taverne-license

Take down policy

If you believe that this document breaches copyright please contact us at:

repository@maastrichtuniversity.nl

providing details and we will investigate your claim.
}

Copyright and moral rights for the publications made accessible in the public portal are retained by the authors and/or other copyright owners and it is a condition of accessing publications that users recognise and abide by the legal requirements associated with these

- Users may download and print one copy of any publication from the public portal for the purpose of private study or research.

- You may not further distribute the material or use it for any profit-making activity or commercial gain

If the publication is distributed under the terms of Article $25 \mathrm{fa}$ of the Dutch Copyright Act, indicated by the "Taverne" license above, 


\section{Polygenic Determination of Cardiovascular Risk}

A Population Study on Arterial Structure and Function 



\section{Polygenic Determination of Cardiovascular Risk}

A Population Study on Arterial Structure and Function

\section{PROEFSCHRIFT}

Ter verkrijging van de graad van doctor, aan de Universiteit Maastricht,

op gezag van de Rector Magnificus, Prof. Dr. A.C. Nieuwenhuijzen Kruseman volgens het besluit van het College van Decanen,

in het openbaar te verdedigen

op donderdag 6 juni 2002 om 16.00 uur

door

Elisabeth J.M. Balkestein

Geboren te Maastricht op 10 oktober 1963 


\section{Promotores:}

Prof. dr. H.A.J. Struijker Boudier

Prof. dr. L.M.A.B. Van Bortel (Universiteit Gent)

\section{Co-promoter}

Dr. J.A. Staessen (Katholieke Universiteit Leuven)

\section{Beoordelingscommissie}

Prof. dr. P.W. de Leeuw (voorzitter)

Dr. P. Boutouyrie (Hôpital Européen Georges Pompidou, Parijs)

Prof. dr. A.P.G. Hoeks

Prof. dr. R.F.M. Vlietinck

Financial support by Pie Medical for the publication of this thesis is gratefully acknowledged 
Ook de langste voetreis begint met de eerste stap Chinees gezegde 



\section{Contents}

Chapter 1 General introduction 9

Chapter 2 Methods 49

Chapter 3 Non-invasive assessment of local pulse pressure Comparison of applanation tonometry and echo-tracking 61

Chapter 4 Carotid and femoral artery stiffness in relation to three candidate genes in a white population $\mathbf{7 5}$

Chapter 5 Modulation of the ACE genotype effect on vascular resistance index by the $\alpha$-adducin polymorphism in the general population 91

Chapter 6 Carotid and femoral intima-media thickness in relation to three candidate genes in a Caucasian population 107

Chapter 7 General discussion 125

Chapter 8 Summary 137

Samenvatting 141

Curriculum Vitae 144

List of Publications 145

Dankwoord 147 

Chapter 1

General Introduction 


\section{Cardiovascular disease and risk factors}

Cardiovascular complications, principally related to arterial injuries, are the first cause of morbidity and mortality in Western countries. In the United States of America, for instance, cardiovascular disease is the cause of more deaths than the next 7 causes of death combined, with a coronary event taking place about every 29 seconds. ${ }^{1}$ The Framingham Heart Study ${ }^{2}$ was the first to identify risk factors for this major public health problem in 1976 and these findings had major clinical implications. Recognition of these risk factors highlighted the possibility of prevention and of reducing cardiovascular morbidity and mortality. World wide, primary and secondary prevention trials have been performed or are ongoing. For instance the benefits of lowering blood pressure and cholesterol have been investigated world wide from Europe ( Syst-Eur, SHEP) ${ }^{3}$ to Australia (Australian National Blood Pressure Study 2) and from Scandinavia (Helsinki Heart Study) to the United States (Hypertension and Lipid Trial), respectively. Although most of the initially listed risk factors are still of major interest, the search for pathophysiologic and genetic mechanisms with which one might interfere continued.

The concept of blood pressure comprising both a static (mean arterial pressure) and a pulsatile component (pulse pressure) led to the recognition of another, possibly independent, risk factor for cardiovascular morbidity and mortality, namely large artery stiffness. ${ }^{4-10}$ Pulse pressure, the difference between systolic and diastolic blood pressure, increases with the left ventricular ejection rate, stiffening of the aorta and the large conduit arteries and wave reflections. ${ }^{11}$ Several studies have investigated the relationship between increased pulse pressure and the risk of cardiovascular morbidity and mortality. Both negative findings and positive associations have been reported. No additional prognostic information to systolic and diastolic blood pressure was attributed to pulse pressure in, for instance four epidemiological studies in Chicago $^{12}$ and in the "Hypertension Detection and Follow-up Program". ${ }^{13}$ On the other hand, numerous studies in normotensive and hypertensive subjects and in post-myocardial infarction patients have shown a positive association and independent correlation between cardiovascular morbidity and mortality and pulse pressure. ${ }^{4,9,14-28}$ As a consequence, the assessment of the stiffness of the large arteries ${ }^{29}$ and the association between known cardiovascular risk factors and vascular stiffness has gained interest over the last decades.

\section{1 large arteries and cardiovascular risk}

The analysis of risk factors in relation to large artery properties has been the subject of a recent thesis from our group ('Large artery properties and cardiovascular risk: a population study' by J.J. van der Heijden-Spek, 2000) and will therefore be reviewed only briefly here.

The effect of age, although dependent on the vascular territory investigated, has been confirmed by several studies. ${ }^{30-39}$ Central arteries (predominantly 
elastic arteries) stiffen progressively with age, whereas the wall characteristics of muscular (more distal) arteries change little with age. ${ }^{36}$

The effect of gender on arterial stiffness, is also different according to the vascular territory. ${ }^{30,32,39}$ However, the published reports not always reflect the same views. For instance, some investigators find no differences between sexes, ${ }^{32}$ while others noticed differences throughout various life-periods ${ }^{34}$ or specified arterial sites. ${ }^{30}$ The hypothesis that increased vascular stiffness is a major mechanism explaining the higher cardiovascular risk of men, remains debated.

The relationship between the function and structure of the large arteries and obesity remains under investigation. ${ }^{40-45}$ In a large population-based study, van der Heijden-Spek et al showed that after adjustment for important covariates and potential confounders, stiffness of the large arteries increased with body-mass index in both sexes. In men, abdominal obesity was associated with increased stiffness of the aorta. ${ }^{46}$ In a recent prospective study by Lakka et $\mathrm{al}^{47}$ abdominal obesity in men was associated with accelerated progression of intima-media thickening of the carotid artery, which leads to increased stiffness ${ }^{48}$ and is considered a preclinical stage of atherosclerosis ${ }^{49,50}$ and a risk factor for cardiovascular disease. ${ }^{51}$

Smoking acutely increases arterial stiffness, ${ }^{52-56}$ but its long term effects on large artery stiffness remain debated. ${ }^{52,54,57,58}$

Few studies focused on arterial function and ethnicity. Especially AfroAmericans have been investigated because of their increased susceptibility to hypertension. ${ }^{59,60}$ Blacks show an alteration of the nitric oxide and isoprotenerol mediated vasodilation. ${ }^{61,62}$ Large scale population studies on the large artery properties of Africans or Afro-Americans have not yet been reported.

The Chinese population, known to exhibit a lower prevalence of atherosclerosis and a higher prevalence of hypertension as compared to the Caucasian population, have a different morphology of the aorta with increasing age. $^{63}$

Diabetes mellitus and other metabolic disorders such as insulin-resistance, hyperlipidaemia and homocysteinuria are associated with increased stiffness of the large arteries. There is consensus that adult diabetic patients compared to non-diabetics have stiffer arteries. ${ }^{64-67}$ However, in children and adolescents with type I diabetes, stiffness has been shown to be either increased ${ }^{68}$ or decreased. ${ }^{69}$ Insulin resistance is related to increased stiffness in middle-aged women ${ }^{70}$ and young healthy women, ${ }^{71}$ but negative findings also have been reported. $^{72,73}$ Hypercholesterolaemia is correlated with increased stiffness both in adults ${ }^{74,75}$ and in children. ${ }^{76,77}$ However, a decreased stiffness has been observed in both very young ${ }^{78}$ or asymptomatic ${ }^{79}$ subjects with hypercholesterolaemia. 
The association between homocysteine and large artery function and geometry is still controversial. ${ }^{80,81}$

The relationship between hypertension and large artery stiffness has been established over the years. ${ }^{82,83}$ Both in young and older hypertensives, the stiffness gradient from central to peripheral arteries is attenuated. ${ }^{84}$ However, the increased stiffness is not equal along the arterial tree. ${ }^{85-87}$ Whether hypertension is caused by increased stiffness or is a result of large artery stiffening is difficult to establish. Essential hypertension can be considered as a dysfunction of the systems that regulate blood pressure. Functional alterations may increase blood pressure by for instance vasoconstriction or activation of salt-and water-retaining mechanisms. The higher blood pressure may then be preserved by the same factors through structural changes. ${ }^{88}$ The ARIC Study showed in a 6-year prospective study in 6992 normotensive subjects, that a decrease of one standard deviation in the elasticity of the common carotid artery was associated with an odds ratio of $1.17(95 \% \mathrm{Cl}$ : 1.05-1.31) for the development of hypertension. ${ }^{89}$ The latter study suggests that a decrease in elasticity of large arteries is the initiator of hypertension and not a consequence.

\section{Genetics and cardiovascular disease}

The two major areas of recent development in terms of cardiovascular risk factors have been: (1) the recognition of the prognostic importance of large artery stiffness in relation to cardiovascular morbidity and mortality and (2) the identification of new genetic risk factors.

Until a few years ago genetics was a field of basic research, but it has grown rapidly to become a discipline of cardiovascular medicine, in which highly technological laboratory investigations and clinical research have been integrated.

Monogenic forms of cardiovascular disease have been described. Although monogenic causes are usually associated with very rare forms of cardiovascular disease, they provide information on possible candidate genes for more common polygenic forms of cardiovascular disease.

\subsection{Heritable disorders of connective tissue}

Marfan's syndrome, a syndrome characterised at the cardiovascular level by a dilatation and dissection of the proximal aorta caused by a degeneration of the elastic fibers of the tunica media, was first described in 1896 by Marfan. It took almost a century before the genetic mutations responsible for this autosomal-dominant condition were discovered. ${ }^{90-92}$ Mutations in the fibrillin-1 (FNB1) gene not only cause Marfan's syndrome, but also other familial forms of isolated thoracic aneurysms, ectopia lentis, arachnodactyly, and 
disproportionate tall stature, along with severe and rare congenital disorders termed neonatal Marfan syndrome and Shprintzen-Goldberg syndrome. ${ }^{93}$

Ehlers Danlos syndrome type IV, an autosomal-dominant disease characterised by thin, translucent and fragile skin is caused by a mutation in the gene encoding the type III collagen polypeptides (COL3A1). The mutation in this gene causes a disruption of the integrity of the vascular wall by a negative effect on the formation of type III collagen. This leads to lifethreatening complications induced by spontaneous rupture or dissections of the aorta or large- to medium-sized arteries.

Elastin plays a role in stabilising arterial wall structures and proliferation of smooth muscle cells. ${ }^{94}$ A mutation in the elastin gene causes a typical vascular lesion of the ascending aorta, the 'hourglass-shaped stenosis'. This aortic lesion is present as an isolated disorder inherited in a autosomal-dominant fashion, the so called supravalvular aortic stenosis (SVAS) or can be part of the Williams-Beuren syndrome. In additon to the aorta, other major arteries, including the pulmonary, carotid, cerebral, renal and coronary arteries may also be stenotic in SVAS patients. ${ }^{93}$ Mutations in the ABCC6 gene lead to pseudoxanthoma elasticum, a genetic disease characterized by proteoglycan accumulation and numerous systemic manifestations. Among these manifestations are large artery calcifications and stenosis resulting in transient ischemic attacks, peripheral occlusive disease and occasionally myocardial infarction in young adults.

The Ser422 allele of the Ser422Gly polymorphism of the elastin gene is associated with a decreased distensibility of the elastic carotid artery. ${ }^{95}$

\subsection{Heart Failure}

Although heart failure is mostly a cardiovascular complication with multiple causes, monogenic forms of cardiac failure have been described. Inborn errors of metabolism, storage diseases or diminished energy production are one class of monogenic disorders in which cardiomyopathies are inherited. Syndrome's like Pompe, Hurler and Fabry (storage diseases) or carnitine deficiency (dimished energy production) are only a few examples of this class of monogenic heart failure.

Neuromuscular disorders are another class of diseases associated with heart failure. Duchenne's muscular dystrophy carried by the X chromosome (Xp21), Becker-type muscular dystrophy (Xp21), Friedrich ataxia, and Refsum disease fall into this category.

Malformations and congenital heart disease will become a growing cause of heart failure due to the expanded possibilities of life-saving surgery in congenital heart disease. The greatest risk factor for having a cardiac malformation is the occurrence of a congenital defect in a parent or an older sibling. ${ }^{97}$ Specific mutations have been described. DiGeorge syndrome (aplasia/hypoplasia of the thymus and parathyroid glands in association with conotruncal defects) is related to a visible or microdeletion of chromosome 
$22 q 11$ in more than $90 \%$ of the cases. An X-chromosome linked disorder, heterotaxy, causes mild or no consequences in women, but complex cardiac malformations in men. The gene for heterotaxy is encoded at Xq24 and mutations are found in a transcription factor (zinc-finger of cerebellum) with homology to proteins involved in left-right axis formation. ${ }^{93,98}$

The Holt-Oram syndrome is an autosomal-dominant genetic disorder which can present itself with either very mild abnormalities in skeletal development and simple atrial- or ventricular septal defects or phocomelia with complex cardiac malformations. In spite of the different clinical presentations, all patients with the Holt-Oram syndrome have a mutation in the TBX5 gene, which encodes a transcription factor, essential for heart formation. ${ }^{93}$ Other monogenic syndromes of which the responsible genes have, however, not yet been identified are the Noonan syndrome and the Kartagener syndrome. The former is inherited in an autosomal dominant fashion and the latter is an autosomal recessive genetic disorder with incomplete penetrance. ${ }^{97}$ Furthermore, several syndromes which frequently, but not obligatorily present with cardiovascular malformations are the Down syndrome, the Turner syndrome and Trisomie 8.

Familial hypertrophic cardiomyopathy may be the results of mutations in the genes encoding cardiac myosin binding protein- $C, \beta$ cardiac myosin heavy chain, $\alpha$ tropomyosin, troponin I, cardiac actin and the myosin light chains. ${ }^{93,99}$ The inheritance of congestive or dilated cardiomyopathy is not well described, but familial factors seem to play a major role, since approximately $30 \%$ of cases are inherited. The X-chromosomal transmission of this cardiomyopathy was recognised as a potential indicator for Duchenne's or Becker's dystrophy, indicating a role for a cytoskeleton protein disorder, since the latter patients exhibit a lack of the membraneous protein dystrophin. Muntoni et al described the mutation of the dystrophin gene, which is also responsible for Duchenne and Becker's dystrophy. ${ }^{100}$ Another X-linked syndrome, the Barth syndrome, is also characterised by dilated cardiomyopathy and has been located at G4.5. ${ }^{101}$ Mutations in the gene coding for cardiac actin, located on chromosome $15 q 14$ may be responsible for some forms of autosomal dominant dilated cardiomyopathy. ${ }^{99,102}$ One rare disorder of which the gene has been identified recently, is the autosomal dominant dilated cardiomyopathy (CMDA1), caused by mutations in the gene encoding nuclear lamins $A$ and C (LMNA gene, chromosome 1q21-q22). ${ }^{103}$ Another mutation, recently described in a cardiomyopathic patient, in the gene encoding the skeleton protein metavinculin, further strengthens the hypothesis of a major role for genes encoding cytoskeleton proteins in the causation of dilated cardiomyopathies. ${ }^{104}$

\subsection{Cardiac Arrhythmias}

Monogenic cardiac arrhythmias, of which the long QT-syndrome is probably the best known, have been described. The European Working Group on 
Arrhythmias provides an overview of the molecular and genetic basis of these monogenic cardiac disorders, ${ }^{102}$ as does a recent review by Keating and Sanguinetti. ${ }^{105}$

The long QT-syndrome can present itself as an autosomal dominant disorder with a pure cardiac phenotype (Romano-Ward) or as a rarer, autosomal recessive disorder characterised by the coexistence of cardiac abnormalities and congenital deafness (Jervell and Lange-Nielsen). Mutations at loci encoding for sub-units for the voltage-gated potassium channel, rapid current delayed rectifier potassium channels and cardiac sodium channels are responsible for the disturbances in the long-QT syndrome.

\subsection{Metabolic disorders leading to cardiovascular complications}

Familial hypercholesterolemia $(\mathrm{FH})$ is an example of a single-gene disorder that results in atherosclerosis and coronary artery disease. The probability for heterozygous males with this disease for experiencing a myocardial infarction before they reach the age of 60 is $75 \%$ as compared to $15 \%$ probability in the general population. The defect lies in the lack of a high-affinity receptor for low-density lipoprotein (LDL). The final description of the mutations in the LDL receptor gene located on chromosome 19p13.2, p13.12 and the pioneering work on familial hypercholesterolaemia made that the 1985 Nobel Prize in medicine was awarded to Brown and Goldstein. This recognition emphasised the importance of cardiovascular genetics. Subsequent studies have identified other loci influencing plasma lipid levels and possibly increasing the risk of coronary artery disease. Among the genes of interest are those encoding for apolipoprotein B-100, apolipoprotein E, lipoprotein(a), lipoprotein lipase, apolipoprotein $\mathrm{CII}$ and triglyceride transfer protein. ${ }^{93,96}$ Tangier disease, characterised by extremely low levels of high-density cholesterol and accumulation of cholesterol in macrophages is caused by mutations in the $\mathrm{ABC1}$ gene on chromosome 9q22-31, encoding a member of the ATP-binding cassette family of transporters.

Although the above-mentioned mutations in the genes coding for proteins that regulate lipoprotein synthesis, interconversions and catabolism are of major importance to those who are carriers of these mutations, polymorphisms in these genes have gained more interest over the last decades due to their possible relationship with cardiovascular risk in the general population. ${ }^{108}$ With the exception of the ApoE polymorphism in which homozygotes of the ,4/,4 have increased, and ,2/,2 homozygotes have decreased cholesterol levels in all investigated populations, other polymorphisms as described in the review of Sankaranarayanan et al, are not uniformly associated with increased levels of cholesterol or increased cardiovascular risk.

Homocysteinuria, a disorder increasing the risk for atherosclerosis, is another single-gene disease with a mutation on chromosome 21q22.3 of the gene encoding cystathionine b-synthase ${ }^{96}$ An increased plasma total homocysteine level confers an independent risk of vascular disease similar to that of smoking 
or hyperlipidaemia. Plausible mechanisms by which homocysteine might contribute to atherogenesis include promotion of platelet activitation and enhanced coagulability, increased smooth muscle cell proliferation, cytotoxicity, induction of endothelial dysfunction and stimulation of LDL oxidation. ${ }^{08}$ A common polymorphism, a mutation in the methylenetetrahydrofolate reductase (MTHFR) gene, is associated with decreased specific MTHFR activity and elevation in homocysteine levels in the homozygous state. However, an association between this polymorphism and an increased risk for myocardial infarction or coronary arterial disease has not been reported. ${ }^{109}$

Several epidemiological studies have identified elevated fibrinogen levels as a potential risk factor in coronary heart disease. Studies on the association between plasma fibrinogen levels and genetic polymorphisms of the fibrinogen gene cluster ( $\alpha, \beta$ and $\gamma$ genes on chromosome 4; 4q26-q28) showed that variation at the $\beta$ locus may be responsible for the elevated levels, but conclusive studies are still to be reported. ${ }^{108}$

Polymorphisms of the genes encoding other factors involved in thrombosis and subsequently their possible increasing effect on protrombotic risk are those involving among others, Plasminogen Activator Inhibitor-1 (PAI-1), Factor V, XIII, VII, XII, protrombin, thrombomodulin and Von Willebrand Factor. However, negative - positive - and null associations have been reported on all these different polymorphisms (Table 1 ). ${ }^{109}$

A very common disease leading to various cardiovascular complications is diabetes mellitus type I and type II.

Among Caucasian patients, the strong and consistent association of type 1, but not type II diabetes mellitus with genes in the HLA (human leucocyte antigen) region has long been known. Several genetic loci, each of which codes for a slighty different glycoprotein have been described, which are highly polymorphic. All the HLA-association studies show that the HLA-locus (now designated as IDDM1) confers strong suspectibility to type I diabetes mellitus, but this is not sufficient to account for the complete genetic contribution to the disease. Non-HLA linked loci have therefore been studied for their contribution to the pathogenesis of type I diabetes. ${ }^{108}$ Research on the latter loci resulted in description of IDDM2, a polymorphic region in the insulin gene on chromosome $11 \mathrm{p} 15.5$ and of at least 11 other loci on different chromosomes.

The impairment of insulin to stimulate glucose uptake and inadequate compensation for altered insulin sensitivity underlie type II diabetes. 
A rare autosomal dominant form of insulin resistance is the Dunnigan-type familial partial lipodystrophy (FPLD) which is often accompanied by type II diabetes and hypertension. A mutant LMNA, which encodes nuclear lamins $A$ and $\mathrm{C}$ underlies this rare disorder. ${ }^{110}$

Mutations responsible for the rare monogenic forms of type II diabetes, known as maturity-onset diabetes of the young (MODY) are described for the genes encoding glucose metabolising enzyme glucokinase, transcription factors HNF1 $\alpha-$ and $\beta, \mathrm{HNF} 4 \alpha$ and insulin promoter factor 1 (IPF1). These mutations all result in $\beta$ cell dysfunction (table 2). ${ }^{111}$ Several candidate genes, for instance in the glucokinase gene region and the sulfonylurea receptor gene have been the subject of several case-control and association studies. Consensus on these polymorphisms and their relationship with diabetes type II has not yet been reached. ${ }^{108}$

\subsection{Hypertension}

Monogenic forms of hypertension, which constitute less than $5 \%$ of all hypertension have been described over the last decades. ${ }^{112}$ Table 3 describes the known (to date) monogenic forms of hypertension.

Glucocorticoid-remediable hypertension was first described by Laidlow et al in $1966^{113}$ and is characterised by an abnormal secretion of 18-hydroxycortisone. A chimeric gene produced by unequal crossover between two closely related forms of cytochrome 450, $11 \beta 1$ (CYP11B1) and $11 \beta 2$ (CYP11B2) hydroxylases has been discovered by using this biological marker as a phenotype in genetic studies. The chimeric gene contains a promoter of the CYP11B1 gene and its expression is regulated by adrenocorticotrophic hormone and can be suppressed by administration of dexamethasone. Other monogenic forms of hypertension are also associated with defects in steroid metabolism. Female pseudo-hermaphroditism, due to a mineralocorticoid excess; male pseudo-hermaphroditism with a mineralocorticoid excess, but accompanied by a lack of cortisol and apparant mineralocorticoid excess with inactivating mutations in the 11ß-hydroxysteroid dehydrogenase gene resulting in failure to provide protection against the mineralocorticoid effect of cortisol.

Abnormalities in renal ion transport are another category of monogenic hypertension. Liddle's syndrome is characterised by a therapeutic response to administration of triameterene. This syndrome is associated with activating mutations in the $\beta$ and $\gamma$ subunits of the aldosterone-regulated amiloridesensitive epithelial sodium channel of the renal tubule. Gordon's syndrome, characterised also by abnormalities in renal ion transport is another monogenic form of hypertension.

A rare monogenic form of hypertension which is the only non- salt-sensitve one, is characterised by hypertension and brachydactyly. The gene for the 
latter form has not yet been identified, but is located on chromosome 12p12.211.2. ${ }^{114}$

Recently, Geller et al described an autosomal dominant form of hypertension which is more pronounced in pregnancy and appears before the age of 20 years, the so-called hypertension exacerbated in pregnancy. ${ }^{115}$ In this disorder a mutation in the mineralocorticoid receptor, explains why it can be activated by steroids lacking a hydroxyl group, such as progesteron. Finally, a missense mutation in peroxisome proliferator-activated receptor gamma leads to a dominant syndrome consisting of hypertension, insulin resistance and diabetes mellitus. ${ }^{116}$

Hypertension as a consequence of increased production of catecholamines due to a genetic defect (neoplasia's of the adrenal medulla and pheochromocytoma), is mostly episodic. ${ }^{117}$

\section{Candidate genes and hypertension}

Monogenic forms of cardiovascular disease, ${ }^{118}$ as well as new insights in the pathophysiology of blood pressure regulation in animals ${ }^{119}$ and humans ${ }^{84}$ (figure 1), gave rise to further research on polymorphisms of candidate genes which might play a role in the general population or in specific subsets of patients. Table 4 supplies a list of some of the most commonly investigated polymorphisms in relation to hypertension.

The first gene found to be associated with essential hypertension was the angiotensinogen gene (AGT). It is located on chromosome 1q42-43 and comprises five exons and four introns spanning $12 \mathrm{~kb}$. One polymorphism of the nearly 20 known molecular variants of this gene is a base-pair substition in position 235 leading to the replacement of threonine by methionine in the protein. In 1992, Jeunemaitre et al showed an association between this polymorphism and hypertension in two genetically distinct populations. ${ }^{120}$ In general, most of the subsequently published association studies confirm the latter relation. ${ }^{121}$ Several other polymorphisms of this gene are still under consideration for an association with hypertension (table 4).

Genetic variation in another component of the renin-angiotensin aldosterone system, the angiotensin II type 1 receptor, has also been subject to intensive research. The $A$ to $C$ conversion at position 1166 of this gene has been reported to be associated with hypertension in three case control studies. ${ }^{122-124}$ No association was reported in one case control study ${ }^{125}$ and of those studies that considered blood pressure as a continuous trait two ${ }^{126,127}$ out of three $e^{126-}$ ${ }^{128}$ reported an association with blood pressure. Similar to the angiotensinogen gene, the angiotensin II type 1 receptor gene has revealed several other loci, possibly related to hypertension. ${ }^{128}$

Genes which are related to sodium transport and are known to play a role in monogenic hypertension, such as Liddle's syndrome, also recieved much attention. Mutations in the $\alpha-\beta$ - and $\gamma$ - subunit of the epithelial amiloridesensitive sodium channel are being investigated at present in relation to hypertension. ${ }^{129-131}$ 
Needless to say, that the number of studies on candidate genes and hypertension is enormous and increasing every day, due to the wide spectrum of mechanisms involved in the regulation of blood pressure. For example, a Medline search for 'polymorphism' \& 'hypertension' for the time period January 2000 - June 2001, provides more than 300 hits. The presentation of all candidate genes currently under investigation would lie outside the scope of this thesis.

\section{Genetic polymorphisms tested in this thesis}

This thesis focuses on three genes: the ACE I/D, $\alpha$-adducin Gly460Trp and the aldosterone synthase $C-344 T$ polymorphisms in the general population. These three genes were chosen since they have been reported to be related to the incidence and prevalence of hypertension in the population we investigated. ${ }^{132}$ The hypothesis for the latter study was that these three genes all share the potential of influencing blood pressure via renal sodium handling (figure 2). ${ }^{133}$ Furthermore, it has been postulated by several authors that not single gene effects, but gene-gene interactions are important in the aetiology of essential hypertension, a multifactorial disease. ${ }^{134-136}$ Our main purpose was to investigate whether the three genes could also act on other intermediate phenotypes related to cardiovascular disease, in particular related to the vascular system. 


\subsection{Angiotensin Converting Enzyme Gene}

The $A C E ~ I / D$ polymorphism: an insertion or deletion of 287 basepairs in intron 16 of chromosome 17 is one of the most investigated polymorphisms in relation to hypertension. The recognition of this polymorphism in the gene encoding for ACE has led to numerous studies on not only hypertension but on several other cardiovascular diseases. ${ }^{137}$

ACE levels are increased with the number of $D$-alleles ${ }^{140}$ and might be responsible for an enhanced production of angiotensin II, a potent vasoconstrictor and vascular growth factor. ${ }^{141,142}$ Furthermore, the inactivation of bradykinin could potentially result in decreased tissue perfusion. Angiotensin-mediated stimulation of plasminogen-activator type 1 may promote the formation of occlusive coronary thrombi. ${ }^{143}$ These possible effects of increased ACE levels and the ready availibility of ACE inhibitors may explain the interest in this polymorphism.

Although the $D$ allele of the ACE gene has been suggested to contribute to the development of hypertension, a meta-analysis by Wang et al, did not confirm this. ${ }^{137}$ Only in specific subgroups there was a positive association between hypertension and the $A C E I / D$ polymorphism. ${ }^{144-151}$ More recently, an association of both systolic and diastolic blood pressure and the ACE I/D polymorphism, with the highest blood pressure values in $D D$ carriers, and the lowest in // carriers was reported for Japanese men. ${ }^{152}$ In contrast, a recent Greek case control study ( $n=94$ ) failed to show an association of hypertension and the ACE I/D polymorphism, though there was an assocation between the $A C E I / D$ polymorphism and the prevalence of the HLA-A2 antigen. ${ }^{153}$

\subsection{Aldosterone Synthase Gene}

Aldosterone is synthesized in the adrenal cortex from deoxycorticosterone by a mitochondrial cytochrome P450 enzyme, aldosterone synthase (CYP11B2). The corresponding gene is located on chromosome 8, band 8q22. It is adjacent to a closely related gene that encodes steroid $11 \beta$-hydroxylase (CYP11B1), an enzyme required for cortisol biosynthesis.

Mutations in CYP11B2 can cause aldosterone deficiency. ${ }^{154}$

Conversely, an inherited form of hypertension, glucocorticoid remediable hyperaldosteronisme, is caused by genetic recombinations between CYP11B1 and CYP11B2 that increase expression of CYP11B2 and lead to inappropiate secretion of aldosterone. ${ }^{114}$ The latter monogenic form of hypertension has led to the assumption that polymorphisms in CYP11B2 might influence aldosterone synthesis. Indeed, a polymorphism in CYP11B2, the replacement of cytosine with thymine, 344 nucleotides upstream form the start of translation 
within a binding site for the transcription factor-1, was related to aldosterone synthesis. ${ }^{155}$ Plasma aldosterone levels were increased in subjects with the $-344 T$ allele in a sample of 114 healthy white males and females.

The association with blood pressure has been reported positive, ${ }^{156-158}$ but most authors report no association. ${ }^{155,159-163}$ Of these studies only one was conducted in a large sample of the general population, ${ }^{159}$ while other studies were either case-control ${ }^{156-158,163}$ with regard to hypertension or were conducted in low-risk subjects, ${ }^{161}$ normotensives, ${ }^{155}$ and patients with previous myocardial infarction. ${ }^{160}$

\section{$4.3 \alpha$-Adducin Gene}

Blood pressure, sodium, and extracellular-fluid homeostasis are, in part, maintained by regulation of sodium reabsorption in the kidney. ${ }^{164}$ Studies in the Milan hypertensive and normotensive strains of rats ${ }^{165}$ and in human beings with essential hypertension ${ }^{166}$ by various techniques, ${ }^{165,167,168}$ suggest that genetic alterations in tubular reabsorption may be a cause of hypertension.

Cytoskeleton proteins seem to be involved in this effect. Cross-immunisation of cytoskeleton proteins between Milan hypertensive and normotensive strains of rats show immunochemical differences in adducin. ${ }^{169}$

Adducin, an $\alpha / \beta$ or $\alpha / \gamma$ heterodimer protein, is thought to regulate cell-signal transduction through changes in the actin cytoskeleton. ${ }^{170,171}$ There is close homology (about 94\%) for the $\alpha$-adducin gene between rats and humans. ${ }^{165}$ Known point mutations, one each in the $\alpha$ and $\beta$ adducin subunits account for up to $50 \%$ of the difference in blood pressure between the Milan hypertensive and normotensive rat strains. ${ }^{165}$ Transfection of hypertensive and normotensive $\alpha$-adducin variants showed that the former increases the surface expression and the maximum velocity of the sodium-potassium pump. ${ }^{172}$ This finding provided the genetic-molecular basis for a constitutive increase of tubular ion reabsorption observed in the Milan hypertensive strain of rat, independent of all other factors which could affect this variable. ${ }^{172}$ Linkage and association studies were subsequently performed in hypertensive patients and controls, and a point mutation (Gly460Trp) was found in the human $\alpha$-adducin gene. ${ }^{173,174}$

Cusi and co-workers showed an association between the $\alpha$-adducin Gly460Trp polymorphism and hypertension in both Italian ( $n=282$ hypertensives, $n=151$ controls) and French ( $n=195$ hypertensives, $n=181$ ) subjects. The odds ratio for hypertension associated with the presence of one or two mutant alleles was $1.60(95 \% \mathrm{Cl}: 1.32-1.92)$ adjusted for age, sex, bodymass index, and country. When adjusted for country only, the odds ratio was 1.80 (95\% $\mathrm{Cl}$ : 1.32-1.92). Greater changes in mean arterial blood pressure after a sodium load and after diuretic treatment were noted for those hypertensives (both Italian and French) who carried the mutant 460Trp allele. ${ }^{173}$ Association studies concerning the $\alpha$-adducin polymorphism and 
hypertension since the first report of Cusi et al have yielded contrasting results.

In Italians from two different town-ships (Sassari and Milan), there was no assocation in Sassarians, whereas hypertension was associated with the $\alpha$-adducin polymorphism in Milan subjects. ${ }^{175}$ Clark et al did not find an association between the $\alpha$-adducin polymorphism and essential hypertension in their case-control study $(\mathrm{n}=128) .{ }^{163}$ In contrast, in a case-control study of Melander et al, ${ }^{176}$ a lower frequency of the 460Trp allele was observed in 294 Swedish hypertensives versus 265 normotensives. There was no association in Finnish hypertensives and pooling of Swedish and Finnish subjects resulted in a persistance of the significantly lower frequency of the $\alpha$-adducin 460Trp allele in hypertensives $(n=374)$ versus normotensives $(n=419)$.

Population-based studies also reported different outcomes on the association of hypertension with the $\alpha$-adducin polymorphism. No association was detected in 904 Afro-Americans studied by Larson et al, ${ }^{177}$ and 572 AfroAmericans in the HyperGen Study. ${ }^{178}$ The latter study did find an association in their white subgroup of 822 subjects between hypertension and the $\alpha$-adducin 460Trp allele. Two other large samples consisting of AfricanAmericans $(n=295)$ and white Americans $(n=279)$ did not reveal an association as reported by Schork et al. In elderly Australian subjects, no association was found for isolated systolic hypertension and the $\alpha$-adducin polymorphism in 211 volunteers (87 subjects with isolated systolic hypertension). ${ }^{179}$ In Asian subjects living in Hawaii or the San Francisco Bay area from Chinese, Japanese or Taiwanese descent, different outcomes have been reported by Ranade et al. ${ }^{180}$ In Chinese subjects a weak - and in Japanese no association was reported. In South African blacks, ${ }^{181}$ there was an association in 331 (148 hypertensives) subjects, despite a low frequency of the $\alpha$-adducin $460 T r p$ allele: $6 \%$ versus $14.8 \%$ in Caucasians. ${ }^{182}$ The latter study by Castellano et $\mathrm{al}^{182}$ reported an association in the general population of 246 subjects with a relative risk for hypertension of approximately 1.6 when carrying at least one 460Trp allele.

Several family-based association studies, reported no association between hypertension and the $\alpha$-adducin polymorphism in Scottish ${ }^{183} \quad(n=375)$, Chinese ${ }^{184}$ and German Caucasian ${ }^{185}$ participants. The variety of outcome on all of the above-mentioned studies is most likely in part due to selection of the study-sample, but more importantly due to the difference in ethnicity. ${ }^{186}$

\section{Intermediate Phenotypes}

\subsection{Large arteries}

Hypertension is considered nowadays as having a pulsatile (pulse pressure) and a steady (mean arterial pressure) component. The increased stiffness of large arteries which leads to an increase in pulse pressure and possibly isolated systolic hypertension, can be regarded as a cardiovascular risk factor $^{187}$ and its additional measurement can improve identification of 
hypertensives at high risk for cardiovascular disease. ${ }^{188}$ Moreover, it has been postulated recently that the flow mediated dilation of the brachial artery predicts endothelium function of resistance arteries in hypertensive patients. ${ }^{189}$ Only a limited number of studies focused on large artery stiffness and genetic polymorphisms. Most of the preceeding work has been done by the group of Benetos. These investigators ${ }^{162,190,191}$ studied pulse wave velocity (PWV), a marker of aortic stiffness, ${ }^{192}$ in relation to $A C E I / D$, angiotensin-Il type 1 receptor and aldosterone synthase gene polymorphisms. In both treated and untreated hypertensive patients, PWV increased with the number of $1166 \mathrm{C}$ alleles of the angiotensin II type 1 receptor $A 1166 C$ polymorphism. ${ }^{190,191}$ An increased PWV was noted in homozygotes for the $I$ allele of the $A C E I / D$ polymorphism in treated hypertensives. However, this association was only significant after adjustment for SBP and DBP. ${ }^{191}$ The C-344 allele of the aldosterone synthase $C$-344T polymorphism was associated with an increased PWV in treated hypertensives. ${ }^{162}$ In a recent study in untreated hypertensives, ${ }^{193}$ this relationship was not confirmed. The latter study reported no association between the ACE I/D polymorphism and PWV or two angiotensinogen gene polymorphisms (T174M, M235T) and PWV. Taniwaki et $\mathrm{al}^{194}$ studied PWV and local carotid stiffness in patients with type II diabetes and age-matched controls. In type II diabetics both PWV and carotid stiffness increased with the number of $I$ alleles of the ACE I/D polymorphism. No study, to date, has reported on the $\alpha$-adducin gene polymorphism and its association with large artery stiffness.

\subsection{Systemic vascular resistance index}

Mean arterial pressure is determined by systemic vascular resistance and cardiac output. Any condition that influences cardiac output or peripheral resistance will have its effect on arterial pressure, assuming that the other of both factors does not change in the opposite direction. This principle of control of blood pressure has led to the distinction in hypertension literature between volume dependent and non-volume dependent hypertension. ${ }^{164}$ Kupari et al reported on the association between gene polymorphism and systemic vascular resistance. ${ }^{161}$ Peripheral resistance was not associated with the aldosterone synthase $C-344 T$ polymorphism in 84 young normotensive subjects. However, both left ventricle end-systolic diameter and left ventricular mass increased with the number of $C$-344 alleles.

Systemic vascular resistance studied in heart failure patients in relation to the $\beta_{2}$ adrenergic receptor polymorphisms, did show a different response to exercise in these patients with heart failure according to their genotype; a depressed cardiac performance was noted in patients carrying the 164lle-, the $16 \mathrm{Gly}$ - or the combination of the 16G/y- and 27G/n-allele of the Trh164lle, Arg16Gly and GIn27Glu polymorphism, respectively. However, basal systemic vascular resistance did not differ across the genotypes. ${ }^{195}$

Several studies investigated the ACE I/D polymorphism with respect to local vascular resistance and/or reactivity in vivo ${ }^{196-200}$ or in vitro. ${ }^{201}$ Renal vascular 
resistance was found to be related to the ACE $D$ allele, with an increased resistance in Japanese insulin dependent diabetics (IDDM), ${ }^{197}$ whereas this association was not found in Canadian IDDM. ${ }^{200}$ In Japanese healthy subjects no differences were found for baseline values of renal artery resistance across the genotypes, but an absent fall in renal artery resistance by an ACE-inhibitor was detected for ACE DD homozygotes. ${ }^{196}$ A blunted response to acetylcholine of fore-arm resistance arteries was also found for ACE DD homozygotes by Perticone et $\mathrm{al}^{198}$ in 32 hypertensives. The latter was not confirmed in a recent study by Gainer et $\mathrm{al}^{199}$ in 14 black and 14 white normotensives. An interactive effect of ethnicity and the ACE I/D polymorphism was, however, noted for bradykinin-induced vasodilation. In vitro, no assocation exists between contractility of mesenteric resistance arteries and the ACE I/D genotype. ${ }^{201}$

Studies on the association between renal vascular resistance and the angiotensin II type 1 (A1166C, G-2228A,) receptor ${ }^{202-204}$ and type 2 (G1675A) receptor ${ }^{202}$ polymorphisms yielded different results. In 39 IDDM patients a lower renal vascular resistance was noted for carriers of the $C$ allele of the angiotensin II type $1 \mathrm{~A} 1166 \mathrm{C}$ polymorphism, ${ }^{203}$ whereas this was not found in 42 essential hypertensives. ${ }^{204}$ An association of the $A 1166 \mathrm{C}$ polymorphism with vascular reactivity of mesenteric resistance arteries was also found absent. ${ }^{201}$ Delles et al ${ }^{202}$ investigated both the G-2228A polymorphism of the angiotensin II type 1 , as well as the $G 1675 A$ polymorphism of the angiotensin II type 2 receptor gene in 120 healthy or mild hypertensive subjects. No association with either polymorphism was found, nor did the response to angiotensin II differ across these genotypes.

\subsection{Intima-media thickness}

A third aspect of this thesis is the study of the association between the aforementioned three candidate genes and intima-media thickness, a vascular wall characteristic which is altered in hypertension ${ }^{205-207}$ and is considered a precursor of atherosclerosis. ${ }^{50,208,209}$ The SMART study reported on the additional value of intima-media measurement of the carotid artery in riskscoring in 570 patients with known vascular and/or cardiovascular disease. The intima-media thickness increased nearly linearly with risk scores, herewith discriminating high- from low risk patients. ${ }^{210}$ In hypertensive patients the measurement of the intima-media thickness of the carotid artery in addition to echocardiography can identify high-risk patients. ${ }^{188}$ In 146 male patients who previously had coronary artery bypass graft surgery, the rate of intima-media thickening of the carotid artery predicted coronary events in a long-term followup study. ${ }^{211}$ In older adults without a history of cardiovascular disease an increase in the carotid intima-media thickness from the lowest to the highest quintile, was associated with a more than 3 -fold higher risk of myocardial infarction or stroke. ${ }^{51}$ Carotid and femoral artery ${ }^{208,212}$ intima-media thickening reflects the multifactorial coronary risk burden. Indeed, carotid and femoral artery intima-media thickness were independent predictors of coronary artery 
disease extent in 224 patients selected for elective coronary angiography. Femoral artery intima-media thickness was the only independent predictor of Gensini scores in these patients. ${ }^{213}$

These findings together with the fact that intima-media thickness can be easily and accurately measured non-invasively, ${ }^{214}$ made intima-media thickness a surrogate end-point of considerable interest.

Intima-media thickness in relation to the $A C E I / D$ polymorphism has been the subject of several studies (table 5), whereas to date, no studies in relation to the $\alpha$-adducin or aldosterone synthase gene polymorphism have been published. 


\section{Outline of this thesis}

Chapter 1 gives a general introduction on the genetics of cardiovascular disease, the role of large arteries in cardiovascular disease and provides our main hypothesis on the role of three candidate genes in vascular function in relation to hypertensive disease.

Chapter 2 describes the study design and methods of measurement. The study is part of the FLEMENGHO study, the Flemish study on Environment, Genes and Health Outcomes. All measurements are based on ultrasound techniques and applanation tonometry where appropriate.

Applanation tonometry cannot be performed at all arterial sites due to obesity, the presence of plaques or to various other reasons. The use of the vessel wall movement contour assessed with the wall - track system is described in Chapter 3 for measurement of pulse pressure at the common carotid artery as a surrogate for pulse pressure assessed with applanation tonometry.

Over the last two decades scientific interest in the structure and function of the large arteries rose considerably, because of the independent role in determining cardiovascular risk. We studied the characteristics of the common carotid and femoral arteries in relation to three candidate genes. Our findings are reported in Chapter 4.

Large artery stiffness plays a major role in determining pulse pressure and can, if increased, result in isolated systolic hypertension. Systemic vascular resistance determines mean arterial pressure which, if increased without a change in cardiac output, can provoke systolic-diastolic hypertension. The effect of the three candidate genes on systemic vascular resistance index were therefore investigated in Chapter 5.

Hypertension can lead to vascular wall changes, reflected in an increase in intima-media thickness, which is a precursor of atherosclerosis. Chapter 6 investigates the effect of the three candidate genes on the intima-media thickness of the common carotid artery and the femoral artery.

In Chapter 7 we present a general discussion of our findings concerning the vascular phenotypes.

Chapter 8 summarises this thesis. 
1. American Heart Association. Cardiovascular diseases. Statistics. In.: Spartanburg Regional Healthcare System; 2001.

2. Kannel WB, McGee D, Gordon T. A general cardiovascular risk profile: the Framingham Study. Am J Cardiol. 1976;38:46-96.

3. SHEP Cooperative Research Group. Prevention of stroke by antihypertensive drug treatment in older persons with isolated systolic hypertension. JAMA. 1991;265:3255-3264.

4. Benetos A, Safar ME, Rudnichi A, Smulyan H, Richard JL, Ducimetiere $P$, Guize L. Pulse pressure: a predictor of long-term cardiovascular mortality in a French male population. Hypertension. 1997;30:14101415.

5. Blacher J, Pannier B, Guerin AP, Marchais SJ, Safar ME, London GM. Carotid arterial stiffness as a predictor of cardiovascular and all-cause mortality in end-stage renal disease. Hypertension. 1998;32:570-574.

6. Blacher J, Guerin AP, Pannier B, Marchais SJ, Safar ME, London GM. Impact of aortic stiffness on survival in end-stage renal disease. Circulation. 1999;99:2434-2439.

7. Safar ME, Siche JP, Mallion JM, London GM. Arterial mechanics predict cardiovascular risk in hypertension. $J$ Hypertens. 1997;15:1605-1611.

8. Arnett DK, Boland LL, Evans GW, Riley W, Barnes R, Tyroler HA, Heiss G. Hypertension and arterial stiffness: the atherosclerosis risk in communities study. Am J Hypertens. 2000;13:317-323.

9. Chae CU, Pfeffer MA, Glynn RJ, Mitchell GF, Taylor JO, Hennekens $\mathrm{CH}$. Increased pulse pressure and risk of heart failure in the elderly. JAMA. 1999;281:634-639.

10. Lehmann ED, Hopkins KD, Rawesh A, Joseph RC, Kongola K, Coppack SW, Gosling RG. Relation between number of cardiovascular risk factors/events and noninvasive Doppler ultrasound assessments of aortic compliance. Hypertension. 1998;32:565-569.

11. Nichols WW, O'Rourke M. McDonald's blood flow in arteries. Theoretical, experimental and clinical principles. Fourth ed. London Sydney Auckland: Arnold E; 1998.

12. Dyer AR, Stamler J, Shekelle RB, Schoenberger JA, Stamler R, Shekelle S, Collette P, Berkson DM, Paul O, Lepper MH, Lindberg HA. Pulse pressure III: Prognostic significance in four Chicago epidemiologic studies. J Chronic Dis. 1982;35:283-294.

13. Abernathy J, Borhani NO, Hawkins CM, Crow R, Entwisle G, Jones JW, Maxwell MH, Langford H, Pressel S. Systolic blood pressure as an independent predictor of mortality in the hypertension detection and follow-up program. Am J Prev Med. 1986;2:123-132.

14. Darne B, Girerd X, Safar M, Cambien F, Guize L. Pulsatile versus steady component of blood pressure: a cross-sectional and a 
prospective analysis on cardiovascular mortality. Hypertension. 1989;13:392-400.

15. Madhavan S, Ooi WL, Cohen H, Alderman MH. Relation of pulse pressure and blood pressure reduction to the incidence of myocardial infarction. Hypertension. 1994;23:395-401.

16. Fang J, Madhavan S, Cohen $\mathrm{H}$, Alderman $\mathrm{MH}$. Measures of blood pressure and myocardial infarction in treated hypertensive patients. $J$ Hypertens. 1995;13:413-419.

17. Franklin SS, Sutton-Tyrrell K, Belle SH, Weber MA, Kuller LH. The importance of pulsatile components of hypertension in predicting carotid stenosis in older adults. J Hypertens. 1997;15:1143-1150.

18. Franklin SS, Khan SA, Wong ND. Is pulse pressure useful in predicting risk for coronary heart disease? The Framingham Heart Study. Circulation. 1999;10:354-360.

19. Millar JA, Lever AF, Burke V. Pulse pressure as a risk factor for cardiovascular events in the MRC mild hypertension trial. $J$ Hypertens. 1999;17:1065-1072.

20. Blacher J, Gasowski J, Staessen JA. Pulse pressure, not mean pressure determines cardiovascular risk in older hypertensive patients. Arch Int Med. 2000;160:1085-1089.

21. Benetos A, Zureik M, Morcet J. A decrease in diastolic blood pressure combined with an increase in systolic blood pressure is associated with high cardiovascular mortality. J Am Coll Cardiol. 2000;35:673-680.

22. Benetos A, Rudnichi A, Safar ME, Guize L. Pulse pressure and cardiovascular mortality in normotensive and hypertensive subjects. Hypertension. 1998;32:560-564.

23. Alderman $\mathrm{MH}$, Cohen $\mathrm{H}$, Madhavan S. Distribution and determinants of cardiovascular events during 20 years of succesful antihypertensive treatment. J Hypertens. 1998;16:761-769.

24. Domanski MJ, Mitchell GF, Norman JE, Exner DV, Pitt B, Pfeffer MA. Independent prognostic information provided by sphygmomanometrically determined pulse pressure and mean arterial pressure in patients with left ventricular dysfunction. J Am Coll Cardiol. 1999;33:951-958.

25. Haider WA, Larson MG, Franklin SS, Levy D. Pulse pressure predicts the new onset of overt heart failure in the community: The Framingham Heart Study. Circulation. 1998;98:321-324.

26. Lee MT, Rosner BA, Weiss ST. Relationship of blood pressure to cardiovascular death: the effect of pulse pressure in the elderly. Ann Epidemiol. 1999;9:101-107.

27. Mitchell GF, Moye LA, Braunwald E, Rouleau J-L, Bernstein V, Geltman EM, Flaker GC, Pfeffer MA, for the SAVE Investigators.

Sphygmomanometrically determined pulse pressure is a powerful independent predictor of recurrent event after myocardial infarction in patients with impaired left ventricular function. Circulation. 1997;96:4254-4260. 
28. Pannier B, Brunel P, El Aroussy W. Pulse pressure and echocardiographic findings in essential hypertension. $J$ Hypertens. 1989;7:127-132.

29. Stergiopulos N, Westerhof N. Determinants of pulse pressure. Hypertension. 1998;32:556-559.

30. Heijden van der-Spek JJ, Staessen JA, Fagard RH, Hoeks APG, Struijker Boudier HAJ, Bortel Van LMAB. Effect of age on brachial artery wall properties differs from the aorta and is gender dependent. Hypertension. 2000;35:637-642.

31. Reneman RS, Merode van T, Hick P, Hoeks APG. Flow velocity patterns in and distensibility of the carotid artery bulb in subjects of various ages. Circulation. 1985;71:500-509.

32. Hansen F, Mangell P, Sonesson B, Lanne T. Diameter and compliance in the human common carotid artery - variations with age and sex. Ultrasound Med Biol. 1995;21:1-9.

33. Benetos A, Laurent S, Hoeks APG, Boutouyrie PH, Safar ME. Arterial alterations with aging and high blood pressure : a noninvasive study of carotid and femoral arteries. Arterioscler Thromb. 1993;13:90-97.

34. Baskett JJ, Lewis RR, Beasley MG, Gosling RG. Changes in carotid artery compliance with age. Age Ageing. 1990;19:241-246.

35. Kelly R, Hayward C, Avolio A, O'Rourke M. Noninvasive determination of age-related changes in the human arterial pulse. Circulation. 1989;80:1652-1659.

36. Laurent S, Lacolley P, Girerd X, Boutouyrie P, Bezie Y, Safar ME. Arterial stiffening: opposing effects of age- and hypertension-associated structural changes. Can J Physiol Pharmacol. 1996;74:842-849.

37. McVeigh GE, Bratelli CW, Morgan DM, Alinder CM, Glasser SP, Finkelstein SM, Cohn JN. Age-related abnormalities in arterial compliance identified by pressure pulse contour analysis: aging and arterial compliance. Hypertension. 1999;33:1392-1398.

38. Merode van T, Hick PJJ, Hoeks APG, Reneman RS. Noninvasive assessment of artery wall properties in children aged 4-19 years. Pediatr Res. 1989;25:94-96.

39. Laogun AA, Gosling RG. In Vivo arterial compliance in man. Clin Phys Physiol Meas. 1982;3:201-212.

40. Toto-Moukouo JJ, Achimastos A, Asmar G, Hugues CJ, Safar ME. Pulse wave velocity in patients with obesity and hypertension. Am Heart J. 1986;112:136-140.

41. Yamashita T, Sasahara T, Pomeroy SE, Collier G, Nestel PJ. Arterial compliance, blood pressure, plasma leptin and plasma lipids in women are improved with weight reduction equally with a meat-based diet and a plant-based diet. Metabolism. 1998;47:1308-1314.

42. Schmieder RE, Messerli FH. Does obesity influence early target organ damage in hypertensive patients? Circulation. 1993;87:1482-1488. 
43. Spek JJ, Hoeks AP, Struijker Boudier HA, Bortel Van LM. Differences in vessel wall properties of large arteries in obese and lean subjects. $J$ Hypertens. 1994;12:s23-s24.

44. Oren S, Grossman E, Frohlich ED. Arterial and venous compliance in obese and non-obese subjects. Am J Cardiol. 1995;77:665-667.

45. Raison $\mathrm{JH}$, Safar ME, London GM. Influence of sex and body weight on forearm hemodynamics in patients with sustained essential hypertension. Am J Hypertens. 1991.

46. Resnick LM, Militiuani D, Cunnings AJ, Pipe JG, Evelhoch JL, Soulen R. Direct magnetic resonance determination of aortic distensibility in essential hypertension: relation to age, abdominal visceral fat, and in situ intracellular free calcium. Hypertension. 1997;30:654-659.

47. Lakka TA, Lakka H-M, Salonen R, Kaplan GA, Salonen JT. Abdominal obesity is associated with accelerated progression of carotid atherosclerosis in men. Atherosclerosis. 2001;154:497-504.

48. Frauchiger B, Schmid HP, Roedel C, Moosmann P, Staub D. Comparison of carotid arterial resistance indices with intima-media thickness as sonographic markers of atherosclerosis. Stroke. 2001;32:836-841.

49. Grobbee DE, Bots ML. Carotid intima-media thickness as an indicator of generalized atherosclerosis. J Intern Med. 1994;236:567-573.

50. O'Leary DH, Polak JF, Kronmal RA, Savage PJ, Borhani NO, Kittner SJ, Tracy R, Gardin JM, Furberg CD. Thickening of the carotid wall. A marker for atherosclerosis in the elderly? Cardiovascular Health Study Collaborative Research Group. Stroke. 1996;27:224-231.

51. O'Leary DH, Polak JF, Kronmal RA, Manolio TA, Burke GL, Wolfson SK Jr. Carotid-artery intima and media thickness as a risk factor for myocardial infarction and stroke in older adults. $N$ Engl $\mathrm{J}$ Med. 1999;340:14-22.

52. Liang Y-L, Shiel LM, Teede H, Kotsopoulos D, McNeil J, Cameron JD, McGrath BP. Effects of blood pressure, smoking and their interaction on carotid artery structure and function. Hypertension. 2001;37:6-11.

53. Failla M, Grappiolo A, Carugo S, Calchera I, Giannattasio C, Mancia G. Effects of cigarette smoking on carotid and radial artery distensibility. $J$ Hypertens. 1997;15:1659-1664.

54. Kool MJF, Hoeks APG, Struijker Boudier HAJ, Reneman RS, Bortel Van LMAB. Short- and long-term effects of smoking on arterial wall properties in habitual smokers. J Am Coll Cardiol. 1993;22:1881-1886.

55. Brunel P, Girerd X, Laurent S, Pannier B, Safar M. Acute changes in forearm haemodynamics produced by cigarette smoking in healthy normotensive non-smokers are not influenced by propranolol or pindolol. Eur J Clin Pharmacol. 1992;84:2418-1425.

56. Berlin I, Cournot A, Renout P, Duchier J, Safar M. Peripheral haemodynamic effects of smoking in habitual smokers. A methodological study. Eur J Clin Pharmacol. 1990;38:57-60. 
57. Stefanadis C, Tsiamis E, Vlachopoulos C. Unfavourable effects of smoking on the elastic properties of the aorta. Circulation. 1997;95:3138.

58. Jonason T, Henrikssen E, Kangro T, Nilsson H, Vessby B, Ringqvist I. Stiffness of the common carotid artery in healthy 50 -year-old subjects. Clin Physiol. 1997;17:569-577.

59. Rahman M, Douglas JG, Wright JTJ. Pathophysiology and treatment implications of hypertension in the African-American population.

Endocrinol Metab Clin North Am. 1997;26:125-144.

60. Burt VI, Cutler JA, Higgins M, Ho ran MJ, Labarthe D, Whelton P, Brown $\mathrm{C}$, Roccella EJ. Trends in the prevalence, awareness, treatment, and control of hypertension in the adult US population. Data from the health examination surveys, 1960-1991. Hypertension. 1995;26:60-69.

61. Lang CC, Stein CM, Brown RM, Deegan R, Nelson R, He HB, Wood M, Wood AJ. Attenuation of isoproterenol-mediated vasodilatation in blacks. N Engl J Med. 1995;333:155-160.

62. Stein CM, Lang CC, Nelson R, Brown C, Wood AJ. Vasodilatation in black Americans: attenuated nitric oxide-mediated responses. Clin Pharmacol Ther. 1997;62:436-443.

63. Virmani R, Avolio AP, Mergner WJ, Robinowitz M, Herderick EE, Cornhill JF, Guo SY, Liu TH, Ou DY, O'Rourke M. Effect of aging on aortic morphology in populations with high and low prevalence of hypertension and atherosclerosis. Comparison between occidental and Chinese communities. Am J Pathol. 1991;139:1119-1129.

64. Ryden-Ahlgren A, Lanne T, Wollmer P, Sonesson B, Hansen F, Sundkvist G. Increased stiffness in women, but not in men, with IDDM. Diabetologia. 1995;38:1082-1089.

65. Dijk van R, Nijpels G, Twisk JWR. Change in common carotid artery diameter, distensibility and compliance in subjects with a recent history of impaired glucose tolerance: a 3 year follow-up study. J Hypertens. 2000;18:293-300.

66. Lambert J, Pijpers R, Ittersum van FJ, Comans EFI, Aarsen M, Pieper Ej, Donker AJM, Stehouwer CDA. Sodium, blood pressure and arterial distensibility in insulin-dependent diabetes mellitus. Hypertension. 1997;30:1162-1168.

67. Kool MJ, Lambert J, Stehouwer CDA, Hoeks AP, Struijker Boudier HA, Bortel Van LM. Vessel wall properties of large arteries in uncomplicated IDDM. Diabetes Care. 1995;18:618-624.

68. Parikh A, Sochett EB, McCrindle BW, Dipchand A, Daneman A, Daneman D. Carotid artery distensibility and cardiac function in adolescents with type 1 diabetes. J Pediatr. 2000;137:465-469.

69. Lehman ED, Gosling RG, Sonsken PH. Arterial wall compliance in diabetes. Diabetic Medicine. 1992;9:114-119.

70. Popele van NM, Westendorp IC, Bots ML, Reneman RS, Hoeks AP, Hofman A, Grobbee DE, Witteman JC. Variables of the insulin resistance syndrome are associated with reduced arterial distensibility in 
healthy non-diabetic middle-aged women. Diabetologia. 2000;43:665672.

71. Giltay EJ, Lambert J, Elbers JM, Gooren LJ, Asscheman H, Stehouwer CD. Arterial compliance and distensibility are modulated by body composition in both men and women but by insulin sensitivity only in women. Diabetologia. 1999;42:214-221.

72. Heijden van der- Spek JJ. Large artery properties and cardiovascular risk: a population study. In: Department of Pharmacology and Toxicology. Maastricht, Leuven: Maastricht University; 2000:147.

73. Hopkins KD, Lehman ED, Gosling RG, Parker JR, Sonksen PH. Biochemical correlates of aortic distensibility in vivo in normal subjects. Clin Sci. 1993;84:593-597.

74. Pitsavos C, Toutouzas K, Dernellis J, Skoumas J, Skoumbourdis E, Stefanadis $\mathrm{C}$, Toutouzas $\mathrm{P}$. Aortic stiffness in young patients with heterozygous familial hypercholesterolemia. Am Heart J. 1998;135:604608.

75. Smilde TJ, Berkmortel van den $\mathrm{FW}$, Wollersheim $\mathrm{H}$, Langen van $\mathrm{H}$, Kastelein JJ, Stalenhoef AF. The effect of cholesterol lowering on carotid and femoral artery wall stiffness and thickness in patients with familial hypercholesterolaemia. Eur J Clin Invest. 2000;30:473-480.

76. Leeson CP, Whincup PH, Cook DG, Mullen MJ, Donald AE, Seymour CA, Deanfield JE. Cholesterol and distensibility in the first decade of life: a population-based study. Circulation. 2000;101:1533-1538.

77. Aggoun Y, Bonnet D, Sidi D, Girardet JP, Brucker E, Polak M, Safar ME, Levy BI. Arterial mechanical changes in children with familial hypercholesterolemia. Arterioscler Thromb Vasc Biol. 2000;20:20702075.

78. Lehman ED, Watts GF, Gosling RG. Aortic distensibility and hypercholesterolemia. Lancet. 1992;340:117-1172.

79. Dart AM, Lacombe F, Yeok JK, Cameron JD, Jennings GL, Laufer E, Esmore DS. Aortic distensibility in patients with isolated hypercholesterolaemia, coronary artery disease, or cardiac transplant. Lancet. 1991;338:270-273.

80. Smilde TJ, Berkmortel van den FWPJ, Boers GDH, Wollersheim H, Boo de $\mathrm{T}$, Langen van $\mathrm{H}$, Stalenhoef AFH. Carotid and femoral artery wall thickness and stiffness in patients at risk for cardiovascular disease, with special emphasis on hyperhomocysteinemia. Arterioscler Thromb Vasc Biol. 1998;18:1958-1963.

81. Demuth K, Moatti N, Hanon O, Benoit MO, Safar M, Girerd X. Opposite effects of plasma homocysteine and the methylenetetrahydrofolate reductase C677T mutation on carotid artery geometry in asymptomatic adults. Arterioscler Thromb Vasc Biol. 1998;18:1838-1843.

82. Green MA, Friedlander R, Boltax AJ, Hadjigeorge CG, GA L. Distensibility of arteries in human hypertension. Proc Soc Exp Biol Med. 1966;121:580-585. 
83. Gribbin B, Pickering TG, Sleight P. Arterial distensibility in normal and hypertensive man. Clin Sci. 1979;56:413-417.

84. Safar ME, London GM. The arterial system in human hypertension. In: Swales JD, ed. Textbook of hypertension. London: Blackwell Scientific; 1994:85-102.

85. Safar ME, Frohlich E D. The arterial system in hypertension: a prospective view. Hypertension. 1995;26:10-14.

86. Laurent S, Girerd X, Mourad JJ. Elastic modulus of arterial artery wall material is not increased in hypertension. Arterioscler Thromb. 1994;14:1233-1231.

87. Hayoz D, Rutschmann B, Perret F, Niederberger M, Tardy Y, Mooser V, Nussberger J, Waeber B, Brunner HR. Conduit artery compliance and distensibility are not necessarily reduced in hypertension. Hypertension. 1992;20:1-6.

88. Krieger JE. New contributions to clinical hypertension from molecular biology. Curr Op Cardiol. 1998;13:312-316.

89. Laio D, Arnett DK, Tyroler HA, Riley WA, Chambless LE, Szklo M, Heiss G. Arterial stiffness and the development of hypertension. Hypertension. 1999;34:201-206.

90. Dietz HC, Cutting GR, Pyeritz RE, Maslen CL, Sakai LY, Corson GM, Puffenberger EG, Hamosh A, Nanthakumar EJ, Curristin SM. Marfan syndrome caused by a recurrent de novo missense mutation in the fibrillin gene. Nature. 1991;352:337-339.

91. Lee B, Godfrey M, Vitale E, Hori H, Mattei MG, Sarfarazi M, Tsipouras $P$, Ramirez F, Hollister DW. Linkage of Marfan syndrome and a phenotypically disorder to two different fibrillin genes. Nature. 1991;352:330-334.

92. Dietz HC, Pyeritz RE. Mutations in the human gene for fibrilin-1 (FBN1) in the Marfan syndrome and related disorders. Hum Mol Genet. 1995;4:1799-1809.

93. Milewicz D, Seidman CE. Genetics of cardiovascular disease. Circulation. 2000;102:IV-103-IV-111.

94. Li DY, Brooke B, Davis EC, Mecham RP, Sorensen LK, Boak BB, Eichwald E, Keating MT. Elastin is an essential determinant of arterial morphogenesis. Nature. 1998;393:276-280.

95. Hanon O, Luong V, Mourad JJ, Bortolotto LA, Jeunemaitre X, Girerd X. Aging, carotid artery distensibility, and the Ser422Gly elastin gene polymorphism in humans. Hypertension. 2001;38:1185-1189.

96. Schunkert $\mathrm{H}$. Molecular genetics of congestive heart failure. Scand Cardiovasc J Suppl. 1998;47:47-53.

97. Clark CF, Beall MH, Perloff JK. Genetics, epidemiology, counseling and prevention. In: Perloff JK, Child JS, eds. congenital heart disease in adults. 1 ed. Philadelphia London Toronto Montreal Sydney Tokyo: W.B. Saunders Company; 1991:141-165. 
98. Kitaguchi T, Nagai T, Nakata K, Aruga J, Mikoshiba K. Zic3 is involved in the left-right specification of the Xenopus embryo. Development. 2000;127:4787-95.

99. Seidman JG, Seidman C. The genetic basis for cardiomyopathy: from mutation identification to mechanistic paradigms. Cell. 2001;104:557567.

100. Muntoni F, Cau M, Congiu R, Arvedi G, Mateddu A, Marrosu MG, Cianchetti C, Realdi G, Cao A, Melis MA. Deletion of the dystrophine musscle-promotor region associated with $\mathrm{X}$-linked dilated cardiomyophaty. N Engl J Med. 1993;329:921-925.

101. Bioni S, D'Adamo P, Maestrini E, Gedeon AK, Bolhuis PA, Toniolo D. A novel X-linked gene, G4.5, is responsible for Barth syndrome. Nat Genet. 1996;12:385-389.

102. Priori SG, Barhanin J, Hauer RNW, Haverkamp W, Jongsma HJ, Kleber AG, McKenna WJ, Roden DM, Rudy Y, Schwartz K, Schwartz PJ, Towbin JA, Wilde AM. Genetic and molecular basis of cardiac arrhythmias: impact on clinical management parts I and II. Circulation. 1999;99:518-528.

103. Hegele RA. Molecular basis of partial lipodystrophy and prospects for therapy. Trends in Molecular Medicine. 2001;7:121-126.

104. Maeda M, Holder E, Lowes B, Valent S, Bies R. Dilated cardiomyopathy associated with deficiency of the cytoskeletal protein metvinculin. Circulation. 1997;95:17-20.

105. Keating MT, Sanguinetti MC. Molecular and cellular Mechanisms of cardiac arrhythmias. Cell. 2001;104:569-580.

106. Bodzioch M, Orso E, Klucken J, Langmann T, Bottcher A, Diederich W, Drobnik W, Barlage S, Buchler C, Porsch-Ozcurumez M. The gene encoding ATP-binding cassette transporter 1 is mutated in Tangier disease. Nat Genet. 1999;22:347-351.

107. Bertolini S, Pisciotta L, Seri M, Cusano R, Cantafora A, Calabresi L, Franceschini G, Ravazzolo R, Calandra S. A point mutation in ABC1 gene in a patient with severe premature coronary heart disease and mild clinical phenotype of Tangier disease. Atherosclerosis. 2001;154:599605.

108. Sankaranarayanan $\mathrm{K}$, Chakraborty $\mathrm{R}$, Boerwinkle $\mathrm{EA}$. Ionizing radiation and genetic risks VI. Chronic multifactorial diseases: a review of epidemiological and genetical aspects of coronary heart disease, essential hypertension and diabetes mellitus. Mutation Research. 1999;436:21-57.

109. Williams MS, Bray PF. Genetics of arterial prothrombotic risk states. Exp Biol Med. 2001;226:409-419.

110. Hegele RA. Premature atherosclerosis associated with monogenic insulin resistance. Circulation. 2001;103:2225-2229.

111. Saltiel AR. New perspectives into the molecular pathogenesis and treatment of type 2 diabetes. Cell. 2001;104:517-529. 
112. Gavras I, Manolis A, Gavras H. Genetic epidemiology of essential hypertension. J Hum Hypert. 1999;13:225-229.

113. Sutherland GR, Ruse JL, Laidlow JC. Hypertension, increased aldosterone secretion and low plasma renin activity relieved by dexamethasone. Can Med Assoc J. 1966;95:1109-1119.

114. Lifton RP, Gharavi AG, Geller DS. Molecular mechanisms of human hypertension. Cell. 2001;104:545-556.

115. Geller DS, Farhi A, Pinkerton N, Fradley M, Moritz M, Spitzer A, Meinke G, Tsai FT, Sigler PB, Lifton RP. Activating mineralocorticoid receptor mutation in hypertension exacerbated by pregnancy. Science. 2000;289:119-123.

116. Barosso I, Gurnell M, Crowley VE, Agostini M, Schwabe JW, Soos MA, Maslen GL, Williams TD, Lewis H, Schafer AJ. Dominant negative mutations in human PPARgamma associated with severe insulin resistance, diabetes mellitus and hypertension. Nature. 1999;402:880883.

117. Hamet P, Pausova Z, Adarichev V, Adaricheva K, Tremblay J. Hypertension: genes and environment. J Hypertens. 1998;16:397-418.

118. Luft FC. Molecular genetics of human hypertension. $J$ Hypertens. 1998;16:1871-1878.

119. Cvetkovic $B$, Sigmund $C D$. Understanding hypertension through genetic manipulation in mice. Kidney Int. 2000;57:863-874.

120. Jeunemaitre $X$, Soubrier F, Kotelevtsev YV, Lifton RP, Williams CS, Charru A, Hunt SC, Hopkins PN, Williams RR, Lalouel JM, Corvol P. Molecular basis of human hypertension: role of angiotensinogen. Cell. 1992;71:169-180.

121. Staessen JA, Kuznetsova T, Wang JG, Emelianov D, Vlietinck R, Fagard R. M235T angiotensinogen polymorphism and cardiovascular renal risk. J Hypertens. 1999;17:9-17.

122. Wang WYS, Zee RYL, Morris BJ. Association of angiotensin II type 1 receptor gene polymorphim with essential hypertension. Clin Genet. 1997;51:31-34.

123. BonnardeauX A, Davies E, Jeunemaitre X, Fery I, Charru A, Clauser E, Tiret L, Cambien F, Corvol P, Soubrier F. Angiotensin II type 1 receptor gene polymorphism in human essential hypertension. Hypertension. 1994;24:63-69.

124. Miyamoto $\mathrm{Y}$, Yoshimasa $\mathrm{T}$, Itoh $\mathrm{H}$, Igaki $\mathrm{T}$, Harada $\mathrm{M}$, Yamashita J, Chun T, Doi T, Ishikawa K, Hori Y, Kuwahara K, Ogawa E, Inoue M, Masuda I, Saito Y, K N. Association of angiotensin II type 1 receptor gene polymorphism with essential hypertension in Japanese. $J$ Hypertens. 1996;14:S29.

125. Takami S, Katsuya T, Rakugi H, Sato N, Nakata Y, Kamitani A, Miki T, Higaki $\mathrm{J}, \mathrm{T} \mathrm{O}$. Angiotensin II type 1 receptor gene polymorphism is associated with increase of left ventricular mass but not with hypertension. Am J Hypertens. 1998;11:316-321. 
126. Hingorani $A D$, Jia $H$, Stevens $P A$, Hopper R, Dickerson JEC, Brown MJ. Renin-angiotensin system gene polymorphisms influence blood pressure and the response to angiotensin converting enzyme inhibition. J Hypertens. 1995;13:1602-1609.

127. Castellano M, Muiesan ML, Beschi M, Rizzoni D, Cinelli A, Salvetti M, Pasini G, Porteri E, Bettoni G, Zulli R, Agabiti-Rosei E. Angiotensin II type I receptor $A / C^{1166}$ polymorphism: relationships with blood pressure and cardiovascular structure. Hypertension. 1996;28:1076-1080.

128. Zhang X, Erdmann J, Regitz-Zagrosek V, Kurzinger S, Hense HW, Schunkert $\mathrm{H}$. Evaluation of three polymorphisms in the promoter region of the angiotensin II type 1 receptor gene. J Hypertens. 2000;18:267272.

129. Iwai N, Baba S, Mannami T, Katsuya T, Higaki J, Ogihara T, Ogata J. Association of sodium channel gamma-subunit promoter variant with blood pressure. Hypertension. 2001;38:86-89.

130. Dong YB, Zhu HD, Baker EH, Sagnella GA, MacGregor GA, Carter ND, Wicks PD, Cook DG, Cappuccio FP. T594M and G442V polymorphisms of the sodium channel beta subunit and hypertension in a black population. J Hum Hypert. 2001;15:425-430.

131. Corvol P, Persu A, Gimenez-roqueplo AP, Jeunemaitre X. Seven lessons from two candidate genes in human essential hypertension. Angiotensinogen and epithelial sodium channel. Hypertension. 1999;33:1324-1331.

132. Staessen JA, Wang J-G, Brand E, Barlassina C, Birkenhager WH, Herrmann S-M, Fagard R, Tizzoni L, Bianchi G. Effects of three candidate genes on prevalence and incidence of hypertension in a Caucasian population. J Hypertens. 2001;19:1349-1358.

133. Barlassina C, Schork NJ, Manunta P, Citterio L, Sciarrone MT, Lanella G, Bianchi G, Cusi D. Synergistic effect of $\alpha$-adducin and ACE genes causes blood pressure changes with body sodium and volume expansion. Kidney Int. 2000;57:1083-1090.

134. Williams SM, Addy JH, Phillips JA 3rd, Dai M, Kpodonu J, Afful J, Jackson H, Joseph K, Eason F, Murray MM, Epperson P, Aduonum A, Wong L-J, Jose PA, Felder RA. Combinations of variations in multiple genes are associated with hypertension. Hypertension. 2000;36:2-6.

135. Lifton RP. Genetic determinants of human hypertension. Proc Nat Acad Sci USA. 1995;92:8545-8551.

136. Frankel WN, Schork NJ. Who's afraid of epistasis. Nat Genet. 1996;14:371-373.

137. Wang J-G, Staessen JA. Genetic polymorphisms in the reninangiotensin system: relevance for susceptibility to cardiovascular disease. Eur J Pharmacol. 2000;410:289-302.

138. Samani NK, Thompson JR, O'Toole L, Channer K, Woods KL. A metaanalysis of the association of the deletion allele of the angiotensionconverting enzyme gene with myocardial infarction. Circulation. 1996;94:708-712. 
139. Agerholm-Larsen B, Nordestgaard BG, Tybjaerg-Hansen A. ACE gene polymorphism in cardiovascular disease. Meta-analyses of small and large studies in whites. Thromb Vasc Biol. 2000;20:484-492.

140. Rigat B, Hubert C, Alhenc-Gelas F, Cambien F, Corvol P, Soubrier F. An insertion/deletion polymorphism in the angiotensin l-converting enzyme gene accounting for half the variance of serum enzyme levels. $J$ Clin Invest. 1990;86:1343-1346.

141. Morishita R, Gibbons GH, Ellison KH, Lee W, Zhang L, Yu H, Kaneda Y, Ogihara T, Dzau VJ. Evidence for direct local effect of angiotensin in vascular hypertrophy. In vivo gene transfer of angiotensin converting enzyme. J Clin Invest. 1994;94:978-984.

142. Müller DN, Bohlender J, Hilgers KF, Dragun D, Costerousse O, Menard $\mathrm{J}$, Luft FC. Vascular angiotensin-converting enzyme expression regulates local angiotensin II. Hypertension. 1997;29:98-104.

143. Lindpaintner K, Pfeffer MA, Kreutz R, Stampfer MJ, Grodstein F, LaMotte $F$. A prospective evaluation of an angiotensin-convertingenzyme gene polymorphism and the risk of ischemic heart disease. $N$ Engl J Med. 1995;332:706-711.

144. Duru K, Farrow S, Wang JM, Lockette W, Kurtz T. Frequency of a deletion polymorphism in the gene for angiotensin converting enzyme is increased in African-Americans with hypertension. Am J Hypertens. 1994;7:759-762.

145. Gu XX, Spaepen M, Guo C, Fagard R, Amery A, Lijnen P, Cassiman JJ. Lack of association between the I/D polymorphism of the angiotensinconverting enzyme gene and essential hypertension in a Belgian population. J Hum Hypert. 1994;8:683-685.

146. Kiema TR, Kauma H, Rantala AO, Lilja M, Reunanen A, Keäniemi YA, Savolainen JM. Variations at angiotensin-converting enzyme gene and angiotensinogen loci in relation to blood pressure. Hypertension. 1996;28:1070-1075.

147. Higashimori K, Zhao Y, Higaki J, Kamitani A, Katsuya T, Nakura J, Miki $\mathrm{T}$, Mikami H, Ogihara T. Association analysis of a polymorphism of the angiotensin-converting enzyme with essential hypertension in the Japanese population. Bioch Biophys Res Commun. 1993;191:399-404.

148. Morise T, Takeuchi Y, Takeda R. Angiotensin-converting enzyme polymorphism and essential hypertension. Lancet. 1994;343:125.

149. Higaki J, Baba S, Katsuya T, Sato N, Ishikawa K, Mannami T, Ogata J, Ogihara T. Deletion allele of angiotensin-converting enzyme gene increases risk of essential hypertension in Japanese men: the Suita study. Circulation. 2000;101:2060-2065.

150. Jian M, Cao X, Huang J, Qi J, Liu G, Wang J, Bai D, Qiao D, Zhao JF, Feng S, Liu L. Polymorphism of angiotensin I converting enzyme gene in the older Chinese: linked to ambulatory blood pressure levels and circadian blood pressure rythm. Int J Cardiol. 1996;55:33-40.

151. O'Donnel CJ, Lindpaintner K, Larson MG, Rao VS, Ordovas JM, Schaefer EJ, Myers RH, Levy D. Evidence for association and genetic 
linkage of the angiotensin-converting enzyme locus with hypertension and blood pressure in men but not women in the Framingham heart study. Circulation. 1998;97:1766-1772.

152. Uemura K, Nakura J, Kohara K, Miki T. Assocation of ACE I/D polymorphism with cardiovascular risk factors. Hum Genet. 2000;107:239-242.

153. Diamantopulos EJ, Andreadis EA, Vassilopulos CV, Tabacilo-Kakou MG, Sfakianakis ME, Tarassi KE, Papasteriades CA. Distribution of different HLA antigens in Greek hypertensives according to the angiotensin-converting enzyme genotype. Am J Hypertens. 2000;13:438-441.

154. Pascoe L, Curnow K, Slutsker L, Rosler A, White PC. Mutations in the human CYP11B2 (aldosterone synthase) gene causing corticosterone mehtyloxidase II deficiency. Proc Nat Acad Sci USA. 1992;89:49965000.

155. Paillard F, Chansel D, Brand E, Benetos A, Thomas F, Czekalski S, Ardaillou R, Soubrier F. Genotype-phenotype relationships for the reninangiotensin-aldosteron system in a normal population. Hypertension. 1999;34:423-429.

156. Brand E, Chatelain N, Mulatero P, Fery I, Curnow K, Jeunemaitre X, Corvol P, Pascoe L, Soubrier F. Structural analysis and evaluation of the aldosterone synthase gene in hypertension. Hypertension. 1998;32:198204.

157. Davies E, Holloway MC, Ingram MC, Inglis GC, Friel EC, Morrison C, Anderson NH, Fraser R, Connell JMC. Aldosterone excretion rate and blood pressure in essential hypertension are related to polymorphic differences in the aldosterone synthase gene CYP11B2. Hypertension. 1999;33:703-707.

158. Tamaki S, Iwai N, Tsujita Y, Kinoshita M. Genetic polymorphisms of CYP11B2 gene and hypertension in Japanese. Hypertension. 1999;33:266-270.

159. Schunkert $H$, Hengstenberg $C$, Holmer SR, Broeckel $U$, Luchner A, Muscholl MW, Kürzinger S, Döring A, Hense H-W, Riegger GAJ. Lack of association between a polymorphism of the aldosterone synthase gene and left ventricular structure. Circulation. 1999;99:2255-2260.

160. Hengstenberg C, Holmer SR, Mayer B, Lowel H, Engel S, Hense HW, Riegger GAJ, Schunkert $\mathrm{H}$. Evaluation of the aldosterone synthase (CYP11B2) gene polymorphism in patients with myocardial infarction. Hypertension. 2000;35:704-709.

161. Kupari M, Hautanen A, Lankinen L, Koskinen P, Virolainen J, Nikkila H, White PC. Associations between human aldosterone synthase (CYP11B2) gene polymorphism and left ventricular size, mass and function. Circulation. 1998;97:569-575.

162. Pojoga L, Gautier S, Blanc H, Guyene T-T, Poirier O, Cambien F, Benetos A. Genetic determination of plasma aldosterone levels in essential hypertension. Am J Hypertens. 1998;11:856-860. 
163. Clark CJ, Davies E, Anderson NH, Farmer R, Friel EC, Fraser R, Connell MC. $\alpha$-Adducin and angiotensin I-converting enzyme polymorphisms in essential hypertension. Hypertension. 2000;36:990994.

164. Guyton AC. Long-term regulation of mean arterial pressure: the renalbody fluid pressure control system; long-term functions of the reninangiotensin system; and mechanisms of hypertension. In: Guyton AC, ed. Textbook of medical physiology. 6 ed. Philadelphia, London, Toronto, Mexico City, Rio de Janeiro, Sydney,Tokyo: Saunders WB,; 1981:259-273.

165. Bianchi G, Tripodi G, Casari G, Salardi S, Barber BR, Garcia R, Leoni P, Torielli L, Cusi D, Ferrandi M, Pinna LA, Baralle FE, Ferrari P. Two point mutations within the adducin genes are involved in blood pressure variation. Proc Natl Acad Sci USA. 1994;91:3999-4003.

166. Ferrari $\mathrm{P}$, Bianchi $\mathrm{G}$. Lessons from experimental genetic hypertension. In: Laragh JH, Brenner BM, eds. Hypertension: pathophysiology, diagnosis and management. 2 ed. New York: Raven Press; 1995:12611279.

167. Ferrandi $M$, Salardi S, Tripodi G, Barassi $P$, Rivera R, Manunta $P$, Goldshleger R, Ferrari P, Bianchi G, Karlish SJD. Evidence for an interaction between adducin and $\mathrm{Na}+-\mathrm{K}_{+}-\mathrm{ATPase}$ : relation to genetic hypertension. Am J Physiol. 1999;277:h1338-1349.

168. Bianchi G, Fox U, Di Francesco GF, Pagetti D. Blood pressure changes produced by kidney cross-transplantation between spontaneously hypertensive rats and normotensive rats. Clin Sci Mol Med. 1974;47:435-448.

169. Ferrandi M, Bianchi G. Genetic mechanism underlying the regulation of urinary sodium excretion and arterial blood pressure: the role of adducin. Acta Physiol Scand. 2000;168:187-193.

170. Hughes CA, Bennet V. Adducin: a physical model with implications for function in assembly of spectrin-actin complexes. $J$ Biol Chem. 1996;270:18990-18996.

171. Matsuoka $Y$, Hughes $C A$, Bennet $V$. Definition of the calmodulin-binding domain and sites of phosphorylation by protein kinases $\mathrm{A}$ and $\mathrm{C}$. J Biol Chem. 1996;271:25157-25166.

172. Tripodi G, Valtora F, Torielli L, Chieregatti E, Salardi S, Trusolino L, Menegon A, Ferrari P, Marchiso PC, Bianchi G. Hypertensionassociated point mutations in the adducin $\alpha$ and $\beta$ subunits affect actin cytoskeleton and ion transport. J Clin Invest. 1996;97:2815-2822.

173. Cusi D, Barlassina C, Azzani T, Casari G, Devoto M, Glorioso N, Lanzani C, Manunta P, Righetti M, Rivera R, Stella P, Troffa C, Zagato L, Bianchi G. Polymorphism of alpha-adducin and salt sensitivity in patients with essential hypertension. Lancet. 1997;349:1353-1357.

174. Casari G, Barlassina C, Cusi D, et al. Association of the alpha-adducin locus with essential hypertension. Hypertension. 1995;25:320-326. 
175. Glorioso N, Manunta P, Filigheddu F, Troffa C, Stella P, Barlassina C, Lombardi C, Soro A, Dettori F, Parpaglia P, Alibrandi MT, Cusi D, Bianchi $\mathrm{G}$. The role of $\alpha$-Adducin polymorphism in blood pressure and sodium handling regulation may not be excluded by a negative association study. Hypertension. 1999;34:649-654.

176. Melander O, Bengtsson K, Orho-Melander M, Lindblad U, Forsblom C, Rastam L, Groop L, Hulthen UL. Role of the Gly460Trp polymorphism of the $\alpha$-adducin gene in primary hypertension in Scandinavians. $J$ Hum Hypertens. 2000;14:43-46.

177. Larson N, Hutchinson R, Boerwinkle E. Lack of assocation of 3 functional gene variants with hypertension in african americans. Hypertension. 2000;35:1297-1300.

178. Province MA, Arnett DK, Hunt SC, Leiendecker-Foster C, Eckfeldt $H$, Oberman A, Ellison RC, Heiss G, Mockrin SC, Williams RR. Association between the $\alpha$-Adducin genes and hypertension in the HyperGEN study. Am J Hypertens. 2000;13:710-718.

179. Alam S, Liyou N, Davis D, Tresillian M, Johnson AG. The 460 Trp polymorphism of the human $\alpha$-adducin gene is not associated with isolated systolic hypertension in elderly Australian Caucasians. J Hum Hypertens. 2000;14:199-203.

180. Ranade K, Hsuing AC, Wu KD, Chang MS, Chen YT, Hebert J, Chen YD, Olshen R, Curb D, Dzau V, Botstein D, Cox D, Risch N. Lack of evidence for an association between $\alpha$-Adducin and blood pressure regulation in asian populations. Am J Hypertens. 2000;13:704-709.

181. Barlassina C, Norton GR, Samani JK, Woodwiss AJ, Candy GC, Radevski I, Citterio L, Bianchi G, Cusi D. $\alpha$-Adducin polymorphism in hypertensives of South African ancestry. Am J Hyper. 2000;13:719-723.

182. Castellano M, Barlassina C, Muiesan ML, Beschi M, Cinelli A, Rossi F, Rizzoni D, Cusi D, Agabiti-Rosei E. Alpha-adducin gene polmorphism and cardiovascular phenotypes in a general population. $J$ Hypertens. 1997;15:1707-1710.

183. Kamitani A, Wong ZYH, Fraser R, Davies DL, Connor JM, Foy CJW, Watt GCM, Harrap SB. Human $\alpha$-adducin gene, blood pressure, and sodium metabolism. Hypertension. 1998;32:138-143.

184. Niu T, Xu X, Cordell HJ, Rogus J, Zhou Y, Fang Z, Lindpainter K. Linkage analysis of candidate genes and gene-gene interactions in Chinese hypertensive sib pairs. Hypertension. 1999;33:1332-1337.

185. Busjahn A, Aydin A, Treuenfeld von N, Faulhaber H-D, Gohlke H-R, Knoblauch $\mathrm{H}$, Schuster $\mathrm{H}$, Luft FC. Linkage but lack of association for blood pressure and the $\alpha$-adducin locus in normotensive twins. $J$ Hypertens. 1999;17:1437-1441.

186. Bianchi G, Cusi D. $\alpha$-Adducin: is the glass half full or half empty? Am J Hypertens. 2000;13:739-743.

187. Blacher J, Asmar R, Djane S, London GM, Safar ME. Aortic pulse wave velocity as a marker of cardiovascular risk in hypertensive patients. Hypertension. 1999;33:1111-1117. 
188. Cuspidi C, Lonati L, Macca G, Sampieri L, Fusi V, Severgnini B, Salerno M, Michev I, Rocanova JI, Leonetti G, Zanchetti A. Cardiovascular risk stratification in hypertensive patients: impact of echocardiography and carotid ultrasonography. J Hypertens. 2001;19:375-380.

189. Bae PJ, Charbonneau F, Schiffrin EL. Correlation of endothelial function in large and small arteries in human essential hypertension. $J$ Hypertens. 2001;19:415-420.

190. Benetos A, Topouchian J, Ricard S, Gautier S, Bonnardeaux A, Asmar R, Poirier O, Soubrier F, Safar ME, Cambien F. Influence of angiotensin II type 1 receptor polymorphism on aortic stiffness in never-treated hypertensive patients. Hypertension. 1995;26:44-47.

191. Benetos A, Gautier S, Ricard S, Topouchian J, Asmar R, Poirier O, Larosa E, Guize L, Safar ME, Soubrier F, Cambien F. Influence of angiotensin-converting enzyme and angiotensin II type 1 receptor gene polymorphisms on aortic stiffness in normotensive and hypertensive patients. Circulation. 1996;94:698-703.

192. O'Rourke MF. Mechanical principles in arterial disease. Hypertension. 1995;26:2-9.

193. Lajemi M, Labat C, Gautier S, Lacolley P, Safar M, Asmar R, Cambien $\mathrm{F}$, Benetos A. Angiotensin II type 1 receptor ${ }^{-153} \mathrm{~A} / \mathrm{G}$ and ${ }^{1166} \mathrm{~A} / \mathrm{C}$ gene polymorphisms and increase in aortic stiffness with age in hypertensive subjects. J Hypertens. 2001;19:407-413.

194. Taniwaki H, Kawagishi T, Emoto M, Shoji T, Hosoi M, Kogawa K, Nishizawa Y, Morii $\mathrm{H}$. Association of ACE gene polymorphism with arterial stiffness in patients with type 2 diabetes. Diabetes Care. 1999;22:1858-1864.

195. Wagoner LE, Craft LL, Singh B, Suresh DP, Zengel PW, McGuire N, Abraham WT, Chenier TC, Dorn GW, Liggett SB. Polymorphism of the $\beta_{2}$-adrenergic receptor determine exercise capacity in patients with heart failure. Circ Res. 2000;86:834-840.

196. Mizuiri S, Hemmi H, Inoue A, Takano M, Kadomatsu S, Tanimoto H, Tanegashima M, Hayashi I, Fushimi T, Hasegawa A. Renal hemodynamic changes induced by captopril an angiotensin-converting enzyme gene polymorphism. Nephron. 1997;75:310-314.

197. Fukumoto S, Ishimura E, Hosoi M, Kawagishi T, Kawamura T, Isshiki G, Nishizawa $\mathrm{Y}$, Morii $\mathrm{H}$. Angiotensin converting enzyme gene polymorphism and renal artery resistance in patients with insulin dependent diabetes mellitus. Life Sci. 1996;59:629-637.

198. Perticone F, Ceravolo R, Maio R, Ventura G, Zingone A, Perrotti N, Mattioli PL. Angiotensin-converting enzyme gene polymorphism is associated with endothelium-dependent vasodilation in never treated hypertensive patients. Hypertension. 1998;31:900-905.

199. Gainer JV, Stein CM, Neal T, Vaughan DE, Brown NJ. Interactive effects of ethnicity and ACE insertion/deletion polymorphism on vascular reactivity. Hypertension. 2001;37:46-51. 
200. Miller JA, Scholey JW, Thai K, Pei YPC. Angiotensin converting enzyme gene polymorphism and renal hemodynamic function in early diabetes. Kidney Int. 1997;51:119-124.

201. Steeds RP, O'Toole LO, Channer KS, Morice AH. Human vascular reactivity and polymorphisms of the angiotensin-converting enzyme and the angiotensin Type 1 receptor. J Vasc Res. 1999;36:445-455.

202. Delles C, Erdmann J, Jacobi J, Fleck E, Regitz-Zagrosek V, Schmieder RE. Lack of association between polymorphisms of angiotensin II receptor genes and response to short-term angiotensin II infusion. $J$ Hypertens. 2000;18:1573-1578.

203. Miller JA, Thai K, Scholey JW. Angiotensin II type 1 receptor gene polymorphism and the response to hyperglycemia in early type 1 diabetes. Diabetes. 2000;49:1585-1589.

204. Spiering W, Kroon AA, Fuss-Lejeune MJJ, Daemen MJAP, Leeuw de $\mathrm{PW}$. Angiotensin II sensitivity is associated with the angiotensin II type 1 receptor $A^{1166} \mathrm{C}$ polymorphism in essential hypertensives on a high sodium diet. Hypertension. 2000;36:411-416.

205. Gariepy J, Simon A, Massonneau, Linhart A, Segond P, Levenson J, Groupe PCVMETRA. Echographic assessment of carotid and femoral arterial structure in men with essential hypertension. Am J Hypertens. 1996;9:126-136.

206. Roman MJ, Saba PS, Pini R, Spitzer M, Pickering TG, Rosen S, Alderman $\mathrm{MH}$, Devereux RB. Parallel cardiac and vascular adaptation in hypertension. Circulation. 1992;86:1909-1918.

207. Bots ML, Hofman A, Bruyn de AM, Jong de PT, Grobbee DE. Isolated systolic hypertension and vessel wall thickness of the carotid artery: the Rotterdam Elderly Study. Arterioscler Thromb. 1993;13:64-69.

208. Megnien JL, Simon A, Gariepy J, Denarie N, Cocaul M, Linhart A, Levenson J. Preclinical changes of extracoronary arterial structures as indicators of coronary atherosclerosis in men. $J$ Hypertens. 1998;16:157-163.

209. Simon A, Gariepy J, Levenson J. Ultrasonographic study of the arterial walls: application to the detection of preclinical atherosclerosis. Arch Mal Coeur Vaiss. 1997;90:7-10.

210. Simons PCG, Algra A, Bots ML, Grobbee DE, Graaf van der Y, for the SMART study group. Common carotid intima-media thickness and arterial stiffness: indicators of cardiovascular risk in high-risk patients: the SMART study (second manifestations of arterial disease). Circulation. 1999;100:951-957.

211. Hodis HL, Mack WJ, LaBree L, Selzer RH, Liu C-R, Liu C-H, Azen SP. The role of carotid arterial intima-media thickness in predicting clinical coronary events. Ann Intern Med. 1998;128:262-269.

212. Gariepy J, Salomon J, Denarie N, Laskri F, Megnien JL, Levenson J, Simon A. Sex and topographic differences in associations between large-artery wall thickness and coronary risk profile in a French working 
cohort. The AXA study. Arterioscler Thromb Vasc Biol. 1998;18:584590.

213. Lekakis JP, Papamichael CM, Cimponeriu AT, Stamatelopoulos KS, Papaionannou TG, Kanakakis J, Alevizaki MK, Papapanogiotou A, Kalofoutis ATh, Stamatelopoulos SF. Atherosclerotic changes of extracoronary arteries are associated with the extent of coronary atherosclerosis. Am J Cardiol. 2000;85:949-952.

214. Willekes C, Hoeks APG, Brands PJ, Willigers M, Reneman RS. Evaluation of off-line automated intima-media thickness detection of the common carotid artery based on M-line signal processing. J Vasc Res. 1999;36:222-228. 
Chapter 2

Methods 
Study population

The Flemish Study on Environment, Genes and Health Outcomes (FLEMENGHO) started in 1985. Its protocol was approved by the Ethics Committee of the University of Leuven. From August 1985 until November 1990, a random sample of the households living in a geographically defined area of Northern Belgium was recruited. ${ }^{1}$ To further investigate the role of genetic factors, from June 1996 until January 1999, the study population was enlarged with nuclear families including children who were at least 10 years old, using the former participants as index persons. ${ }^{1}$ The participants or their parents gave informed consent. The participation rate among all subjects contacted was $64.3 \%$.

For this thesis 442 subjects were examined, of which two were excluded because of the inability to perform the vascular examination. For each substudy, characteristics are given for the number of subjects included in that study. For the study of vessel wall properties in relation to genes, data from an earlier phase of the FLEMENGO study were added. ${ }^{2}$ The total population amounted to 756 persons with all outcome- and confounding variables present.

The original population of 440 subjects consisted of 220 men and 220 women. Mean age was 40 years (range $12-76) .27 .5 \%(n=121)$ of the population smoked and $54.3 \%(n=239)$ drank alcohol. Hypertension was present in $16.4 \%$ $(n=72)$ of the population and $12.5 \%(n=55)$ used anti-hypertensive treatment. Diabetes was present in 4 females. Descriptive characteristics by gender are given in table 1. 


\section{Study design}

Participants of the study were asked to come to the examination centre for three hours. Written, and verbally confirmed instructions were given to subjects, such that subjects were asked to refrain from smoking, drinking alcohol and caffeine-containing beverages for three hours prior to the examination. Furthermore subjects were asked not to exercise heavily and have only a light meal before coming to the centre.

At the centre a venous blood sample was drawn for genotyping and biochemical assessments. A trained nurse interviewed the participants with the use of a standardised questionnaire about their health status, their medical history, family history, use of medication, current and past smoking and drinking habits, physical activity level and occupation. Height and weight were measured, as were hip-, waist- and arm-circumferences. Blood pressure cuffs were adjusted to arm-circumference. ${ }^{3}$ After 5 ' of sitting, five consecutive blood pressure measurements were taken with a sphygmomanometer and pulse rate was assessed. Systolic blood pressure (Korotkov Phase I) and diastolic blood pressure (Korotkov Phase V) were used for characterisation of subjects. The mean of 5 readings was taken as the subject's value. Hypertension was diagnosed if the average of the 5 blood pressure readings was at least $140 \mathrm{~mm} \mathrm{Hg}$ systolic or $90 \mathrm{~mm} \mathrm{Hg}$ diastolic, or when the subjects were on antihypertensive medication. Before the vascular examinations took place, subjects rested for $15^{\prime}$ in a supine position. During the whole examination, with exception of the time of examining the brachial artery, blood pressure and heart rate were recorded using a semi-automated oscillometric device (Dinamap, Critikon, Tampa, Florida, USA) every three minutes on the right arm. The means of systolic, diastolic and mean arterial pressures from these recordings were used for calculation of local pulse pressure. Vascular examination of the right common carotid, right brachial and right femoral artery were performed consecutively after 15 minutes of supine rest. At the end of the examination, echocardiography was performed. First, from the sternal notch, aortic flow signals were obtained; thereafter, 2D echocardiography was performed and M-mode tracings were obtained, with the subject in the left lateral decubitus position.

\section{Determination of genotypes}

\section{Genotyping of I/D Angiotensin-converting enzyme polymorphism}

The ACE I/D polymorphism was detected as previously described by Lindpaintner et al. ${ }^{4}$ Genomic DNA (100 ng) was amplified in a total volume of $30 \mu \mathrm{L}$ containing $18 \mathrm{pmol}$ of each primer, $670 \mathrm{mmol} / \mathrm{L}$ Tris- $\mathrm{HCl}, \mathrm{pH} 8.8,160$ $\mathrm{mmol} / \mathrm{L}\left(\mathrm{NH}_{4}\right)_{2} \mathrm{SO}_{4}, 0.5 \% \mathrm{NP} 40,50 \mathrm{mmol} / \mathrm{L} \beta$ mercaptoethanol, $1.3 \mathrm{mmol} / \mathrm{L}$ $\mathrm{MgCl}_{2}, 200 \mu \mathrm{mol} / \mathrm{L}$ of each deoxynucleotide triphosphate and $1 \mathrm{U}$ Taq 
polymerase. The sense primer was 5' GCCCTGCAGGTGTCTGCAGGATGT 3', and the antisense primer was 5' GGATGGCTCTCCCCGCCTTGTCTC 3'. Amplification was carried out by 35 cycles of $30^{\prime \prime}$ at $94^{\circ} \mathrm{C}, 45^{\prime \prime}$ at $56^{\circ} \mathrm{C}$ and $2^{\prime}$ at $72^{\circ} \mathrm{C}$. All samples genotyped as $D D$ underwent a second polymerase chain reaction using insertion-specific primers. ${ }^{4,5} \mathrm{PCR}$ conditions were as before except for an annealing temperature of $67^{\circ} \mathrm{C}$. The sense primer was 5' TGGGACCACAGCGCCCGCCACTAC 3', the antisense primer was 5' TCGCCAGCCCTCCCATGCCCATAA 3'.

\section{Genotyping of Gly460Trp $\alpha$-adducin polymorphism}

Allelic discrimination of the Gly460Trp $\alpha$-adducin polymorphism was carried out using a 5' nuclease assay ${ }^{6}$ on an ABI Prism 7700 apparatus (Perkin Elmer, Norwalk, CT). The forward and reverse primers and the 460Gly and 460Trp probes employed in the TAQMan assay were 5'CGTCCACACCTTAGTCTTCGACTT-3', 5'-GGAGAAGACAAGATGGCTGAACTC-3', 5'-FAMTTCCATTCTGCCCTTCCTCGGA-TAMRA-3' and 5'-TETTTCCATTCTGCCATTCCTCGGAA-TAMRA-3', respectively. Per $25 \mu \mathrm{L}$, the PCR fluid contained $50 \mathrm{ng}$ DNA, $300 \mathrm{nmol}$ primers, $100 \mathrm{nmol}$ FAM-probe and $50 \mathrm{nmol}$ TET-probe. The amplification conditions were $50^{\circ} \mathrm{C}$ for $2^{\prime}, 95^{\circ} \mathrm{C}$ for $10^{\prime}, 95^{\circ} \mathrm{C}$ for $15^{\prime}$ and $62^{\circ} \mathrm{C}$ for $1^{\prime}$ for 40 cycles.

\section{Genotyping of aldosterone synthase C-344T polymorphism}

For amplification of the genomic region encompassing the biallelic polymorphism (C-344T) of the aldosterone synthase gene, ${ }^{7}$ a total volume of $50 \mu \mathrm{L}$ was used, containing $100 \mathrm{ng}$ DNA, $10 \mathrm{mmol} / \mathrm{L}$ Tris $\mathrm{HCL}(\mathrm{pH} 9), 50$ $\mathrm{mmol} / \mathrm{L} \mathrm{KCL}, 1.5 \mathrm{mmol} / \mathrm{L} \mathrm{MgCl}_{2}, 0.1 \%$ Triton X-100, $0.2 \mathrm{mg} / \mathrm{mL}$ BSA, $200 \mu / \mathrm{L}$ dNTPs, $25 \mathrm{pmol}$ of primer CAGGGGGTACGTGGACATTT and primer CAGGGCTGAGAGGAGTAAAA (for position -440 and position -307 respectively in the promoter region) and $0.2 \mathrm{U}$ Taq polymerase (ATGC Biotechnologie). Samples were denaturated $94^{\circ} \mathrm{C}$ for $5^{\prime}$, followed by 35 amplification cycles at $94^{\circ} \mathrm{C}$ for $30^{\prime \prime}, 52^{\circ} \mathrm{C}$ for $30^{\prime \prime} 72^{\circ} \mathrm{C}$ for $30^{\prime \prime}$ and 1 cycle at $72^{\circ} \mathrm{C}$ for $10^{\prime}$.

After enzymatic amplification, one fifth of the PCR product was denatured in $150 \mu \mathrm{L}$ of $0.5 \mathrm{~mol} / \mathrm{L} \mathrm{NaOH}$ and $1.5 \mathrm{~mol} / \mathrm{L} \mathrm{NaCl}$ and blotted onto nylon membranes $\left(\mathrm{N}_{+}, \mathrm{ICN}\right)$. Membranes were neutralized in 2X SSC and crosslinked with UV light. Genotyping was performed by using allele-specific oligonucleotides. Each membrane was hybridized in 7\% polyethylene glycol$10 \%$ SDS at $50 \%$ for 4 hours with 100 pmol of either TCCAAGGCTCCCTCTCA or TCCAAGGCCCCCTCTCA, end labeled with $\left[\gamma_{-}{ }^{32} \mathrm{P}\right] A T P$. Membranes were first washed twice at room temperature in $1 \times$ SSC for $5^{\prime}$ and second for $5^{\prime}$ in $0.5 \times \mathrm{SSC}$ at $52^{\circ} \mathrm{C}$, followed by autoradiography. 


\section{Vascular Ultrasound Examinations}

To examine vascular wall properties an ultrasound-based wall tracking system was used as described by Hoeks et al. ${ }^{8}$

Reproducibility $(n=10)$, for the measurements described below, as expressed as coefficients of variance is given in table 2 .

\section{Common Carotid Artery}

The right common carotid artery (CCA) was examined with B-mode echography with a $7.5 \mathrm{MHz}$ transducer. If no plaques were identified on a longitudinal view from different angulations, an M-mode was performed $2 \mathrm{~cm}$ proximal from the carotid bulb with the M-line perpendicular to the CCA wall. A plaque was defined as a distinct area where the intima-media encroached into the vessel lumen and where it's thickness was at least $50 \%$ greater than that of the adjacent sites. ${ }^{9}$ RF-signals were tracked for measurement of the diameter (D) and change in diameter throughout the heart cycle ( $d=$ distension). The same RF-signal was then used for tracking of the internal diameter (Di). Diameter was defined as the distance from the first upstroke of the adventitia of the anterior wall to the media-adventitia interface of the farr wall. Internal diameter was defined as the distance from the first upstroke of the adventitia of the anterior wall to the lumen-intima-media interface of the far wall (figure). ${ }^{10}$ Three recordings were made lasting 5.2 seconds each.

Whenever a plaque was noted at the right CCA, the left CCA was scanned. If this artery was free of plaques, this artery was used for wall tracking. If plaques were present at both arteries, the right common carotid artery was used for measurement of D and Di (plaque included).

Applanation tonometry was performed at the right CCA, if no plaque was detected. When the right CCA was not suitable for tonometry, the left CCA was used if possible. Three measurements, lasting 5.2 seconds each, were taken at the site of maximal pulsation, with a stable baseline, maximal amplitude and reasonable configuration of the wave contour. ${ }^{11,12}$

\section{Brachial Artery}

Applanation tonometry was performed on the right brachial artery (BA) with the arm in extension, or slight overextension. At the site of maximal pulsation three measurements of 5.2 seconds were recorded.

Brachial artery wall properties were assessed at the right arm, with the arm fixed in a holder to restrict the subject from movement. The transducer was placed above the fossa cubita in a layer of $1.5 \mathrm{~cm}$ of ultrasound transmission gel to avoid pressure on the vessel. When the maximal diameter was 
visualised, the transducer, held in a stereostactic arm, was fixed and three consecutive measurements (lasting 5.2 seconds) were taken. For each measurement, diameter and internal diameter if possible, were tracked from the same RF-signal.

Diameter was defined as the distance between one third of the adventitia thickness of the anterior wall to the media-adventitia interface of the far wall. Internal diameter was defined as the distance between one third of the adventitia thickness of the anterior wall to the lumen-intima-media interface of the far wall.

\section{Femoral Artery}

The common femoral artery (FA) was examined at the right side. M-mode recording was done approximately $1 \mathrm{~cm}$ proximal to the branching of the common femoral artery into the superficial and the profound femoral artery, after B-mode scanning of the FA. Plaques were noted if present. Whenever possible, plaques were not included in measurement of internal diameter.

Three measurements of 5.2 seconds were performed with acquisition of the external and internal diameter from the same RF-signal. Diameter and internal diameters were defined as described above for the brachial artery. 
Off Line Calculations of Wall Properties and Intima Media Thickness

Wall properties

Distensibility Coefficient (DC) and Cross-sectional Compliance (CC) were calculated as follows ${ }^{13}$ :

$\mathrm{DC}=(\Delta \mathrm{A} / \mathrm{A}) / \Delta \mathrm{P} \quad\left(10^{-3} \cdot \mathrm{kPa}^{-1}\right)$

$\mathrm{CC}=(\Delta \mathrm{A} / \Delta \mathrm{P}) \quad\left(\mathrm{mm}^{2} . \mathrm{kPa}^{-1}\right)$

With $\Delta \mathrm{A}$ being the difference between systolic and diastolic cross-sectional area of the artery and calculated from diameter (D) and distension (d):

as: $\quad \Delta \mathrm{A}=\pi((\mathrm{D}+\mathrm{d}) / 2)^{2}-\pi(\mathrm{D} / 2)^{2}$

$\Delta \mathrm{P}$ as the local pulse pressure derived from the calibrated tonometry signal.

The tonometry pulse wave contour was calibrated using Matlab software (The Math Works, version 5.2.0.3084). Assuming diastolic pressure and mean arterial pressure equal over the arterial tree, systolic pressure was calculated from the area under the curve. ${ }^{14}$ Whenever tonometry was not possible, due to obesity, presence of plaques or otherwise, $\Delta \mathrm{P}$ was assessed by means of calculating systolic pressure from the area under the curve as above, with use of the vessel wall contour wave instead of the tonometrically derived pulse wave contour. This method will be described in detail in chapter $3{ }^{15}$

\section{Intima media thickness}

Intima media thickness (IMT) was calculated as:

$\mathrm{IMT}=\mathrm{D}-\mathrm{Di}$

Where $D=$ mean of on average 5 heartbeats and $\mathrm{Di}=$ mean of on average 5 heartbeats of the same RF-signal, tracked for 5.2 seconds. The mean of three intima-media thicknesses was taken as the subjects value.

Cardiac Ultrasound Examination

Cardiac structural and functional measurements were assessed with the echoDoppler technique. Reproducibility $(n=10)$, expressed in coefficients of variance, is given in table 3 for the measurements described below.

\section{Cardiac output}

From the sternal notch, using a 2,25 MHz continuous wave pulsed Doppler transducer, aortic ascending flow signals were visualised. ${ }^{16}$ When maximal flow was achieved with the least dispersion and detection of valve closure, at least five consecutive heart beats were recorded on videotape. Heart rate was recorded simultaneously.

Aortic diameter was measured with the subject in the left lateral position. A short axis view of the aorta in B-mode was performed. With at least two aortic cusps visualised, M-mode recordings were made for five consecutive heart beats and videotaped. ${ }^{17}$ 


\section{Off Line Calculations of Cardiac Output}

Calculation of cardiac output (CO).

CO was calculated off-line with the use of the velocity time integral, assessed from tracing the Doppler signal from the videotape and calculation of the aorta cross sectional area (CSA) by measurement of end diastolic aortic diameter (Dd) according to the American Society of Echocardiography.

$\mathrm{CO}$ was calculated using the formula:

$\mathrm{CO}(\mathrm{L} / \mathrm{min})=\mathrm{VTI}(\mathrm{m} / \mathrm{s}) \times \mathrm{CSA}\left(\mathrm{mm}^{2}\right) \times \mathrm{HR}$

With CSA $\left(\mathrm{mm}^{2}\right)=\pi(\mathrm{Dd} / 2)^{2}$

From CO and mean arterial pressure, systemic vascular resistance (SVR) was calculated as follows: SVR = MAP / CO

For analysis CO and SVR were indexed for body surface area which was calculated according to the formula ${ }^{18}$ : BSA $\left(\mathrm{m}^{2}\right)=$ body weight $(\mathrm{kg})^{0.425} \mathrm{x}$ body height $(\mathrm{cm})^{0.725} \times 71.84$

Statistical analysis

Database management and statistical analysis was performed with the use of the Statistical Analysis System (SAS Institute, Cary, North Carolina, USA) version 8.01 for Windows. Unpaired student's $t$ test was performed to test gender differences on main characteristics.

Stepwise linear regression or logistic regression identified significant covariables. Potentially important covariables were forced into the models where appropriate, regardless of statistical significance.

Genotypes were represented by dummy-variables using the deviation from mean coding approach, ${ }^{19}$ which does not imply any genetic hypothesis. This coding expresses the effect of the genotype as the deviation of the "group mean" from the "overall" mean (=population mean). Coding is obtained by setting the value of all the design variables equal to -1 for one genotype and then using 0 and 1 for the remainder two genotypes. For example, for the ACE I/D genotype, coding is as follows:

\begin{tabular}{lll}
\hline & $\mathrm{D} 1$ & $\mathrm{D} 2$ \\
\hline II genotype & -1 & -1 \\
ID genotype & 1 & 0 \\
$D D$ genotype & 0 & 1 \\
\hline
\end{tabular}

In the regression model, in which all significant covariables and design variables are entered, the $\beta$-coefficient for design variable D1 gives the mean deviation from the population mean for having the ID genotype, and the 
$\beta$-coefficient for D2 gives the mean deviation from the population mean for having the DD genotype.

In a second analysis with the same covariables entered, coding is repeated with the genotype DD set to -1 with different design variables as follows:

\begin{tabular}{lll}
\hline & $\mathrm{A} 1$ & $\mathrm{~A} 2$ \\
\hline II genotype & 0 & 1 \\
ID genotype & 1 & 0 \\
$D D$ genotype & -1 & -1 \\
\hline
\end{tabular}

In the regression model the $\beta$-coefficient for A1 equals D1 in the first model, whereas the $\beta$-coefficient of $A 2$ gives the deviation from the population mean for having the II genotype.

In single gene analysis where independent hypotheses were tested, $\alpha$-levels and confidence intervals were adjusted for multiple testing using Bonferroni's method. ${ }^{20}$

Since our studied population consisted of households or nuclear families and family members are more likely to share identical alleles, we performed (or repeated: chapter 4 ) the analyses using generalized estimating equations to account for the possible non-independence of the outcome variables within families. In the PROC GENMOD procedure normal and logit link functions for continuous and dichotomous variables respectively, were used. Intrafamilial correlation matrices were defined for the investigated phenotypes with adjustments applied for covariables and confounders. 
1. Staessen JA, Roels HA, Emalianov D, Kuznetsova T, Thijs L, Vangronsveld J, Fagard R, for the Public Health and Environmental Exposure to Cadmium (PheeCad) Study Group. Environmental exposure to cadmium, forearm bone-density, and risk of fractures: prospective population study. Lancet. 1999;353:1140-1144.

2. Staessen JA, Wang J-G, Brand E. Association between blood pressure, hypertension and polymorphisms of the aldosterone synthase and $\alpha$ adducin genes in a Belgian population study. J Mol Med. 2000;78:b8.

3. Russell AE, Wing LMH, Smith SA, Aylward PE, McRitchie RJ, Hassam RM. Optimal size of cuff bladder for indirect measurement of arterial pressure in adults. J Hypertens. 1986;7:607-613.

4. Lindpaintner K, Pfeffer MA, Kreutz R, Stampfer MJ, Grodstein F, LaMotte F. A prospective evaluation of an angiotensin-convertingenzyme gene polymorphism and the risk of ischemic heart disease. $N$ Engl J Med. 1995;332:706-711.

5. Barlassina C, Schork NJ, Manunta P, Citterio L, Sciarrone MT, Lanella G, Bianchi G, Cusi D. Synergistic effect of $\alpha$-adducin and ACE genes causes blood pressure changes with body sodium and volume expansion. Kidney Int. 2000;57:1083-1090.

6. Livak KJ, Flood SJ, Marmaro J, Giusti W, Deetz K. Oligonucleotides with fluorescent dyes at opposite ends provide a quenched probe system useful for detecting PCR product and nucleic acid hybridization. PCR Methods Appl. 1995;4:357-362.

7. Brand E, Chatelain N, Mulatero P, Fery I, Curnow K, Jeunemaitre X, Corvol P, Pascoe L, Soubrier F. Structural analysis and evaluation of the aldosterone synthase gene in hypertension. Hypertension. 1998;32:198204.

8. Hoeks APG, Brands PJ, Smeets FAM, Reneman RS. Assessment of the distensibility of superficial arteries. Ultrasound Med Biol. 1990;16:121128.

9. Salonen JT, Salonen R. Ultrasound B-mode imaging in observational studies of atherosclerotic progression. Circulation. 1993;87:II-56-II-65.

10. Girerd X, Mourad JJ, Acar C, Heudes D, Chiche S, Bruneval P, Mignot JP, Billaud E, Safar M, Laurent S. Noninvasive measurement of medium-sized artery intima-media thickness in humans: in vitro validation. J Vasc Res. 1994;31:114-120.

11. Kelly R, Hayward C, Ganis J, Daley J, Avolio A, O'Rourke M. Noninvasive registration of the arterial pressure pulse waveform using high-fidelity applanation tonometry. J Vasc Med Biol. 1989;1:142-149.

12. Chen C-H, Ting C-T, Nussbacher A, Nevo E, Kass DA, Pak P, Wang S$P$, Chang M-S, Yin FC. Validation of carotid artery tonometry as a means of estimating augmentation index of ascending aortic pressure. Hypertension. 1996;27:168-175.

13. Hoeks APG, Reneman RS. Biophysical principles of vascular diagnosis. J Clin Ultrasound. 1995;23:71-79. 
14. Drzewiecki GM, Melbin J, Noordergraaf A. Arterial tonometry: review and analysis. J Biomech. 1983;16:141-152.

15. Bortel Van LM, Balkestein EJ, Heijden van der-Spek JJ, Vanmolkot FH, Staessen JA, Kragten JA, Vredeveld JW, Safar ME, Struijker Boudier HA, Hoeks AP. Non-invasive assessment of local arterial pulse pressure: comparison of applanation tonometry and echo-tracking. $J$ Hypertens. 2001;19:1037-1044.

16. Huntsman LL, Stewart DK, Barnes SR, Franklin SB, Colocousis JS, Hessel EA. Noninvasive Doppler determination of cardiac output in man; clinical validation. Circulation. 1983;67:593-602.

17. Sahn DJ, DeMaria A, Kisslo J, Weyman A. Recommendations regarding quantitation in M-mode echocardiography: results of a survey of echocardiographic measurements. Circulation. 1978;58:1072-1083.

18. Du Bois D, Du Bois EF. A formula to estimate the approximate surface area if height and weight be known. Arch intern Med. 1916;17:863-871.

19. Hosmer DW Jr, Lemeshow S. Interpretation of the fitted model. In: Shewhart WA, Wilks SS, eds. Applied Logistic Regression. second ed. New York: John Wiley \& Sons, Inc.; 2000:56-62.

20. Bland JM, Altman DG. Multiple significance tests: the Bonferroni method. BMJ. 1995; 310:170. 
Chapter 3

Non-invasive Assessment of Local Arterial Pulse Pressure Comparison of Applanation Tonometry and Echo-tracking

L.M. Van Bortel

E.J. Balkestein

J.J. van der Heijden-Spek

F.H. Vanmolkot

J.A. Staessen

J.A. Kragten

J.W. Vredeveld

M.E. Safar

H.A. Struijker Boudier

A.P. Hoeks

Previously published in: J Hypertens 2001; volume 19; pp 1037-1044 


\section{Summary}

Objectives: Pulse pressure is not constant throughout the arterial tree. Use of pulse pressure at one arterial site as surrogate for pulse pressure at another arterial site may be erroneous. The present study compares 3 non-invasive techniques to measure local pulse pressure: [1] internally calibrated readings from applanation tonometry , [2] alternative calibration of pressure waves obtained with applanation tonometry and alternative calibration of arterial distension waves obtained with echo-tracking. Alternative calibration assumes mean and diastolic blood pressure constant throughout the large artery tree.

Design and methods: Study 1 uses invasive measurements in the ascending aorta as reference method and internally calibrated tonometer readings and alternatively calibrated pressure waves at the common carotid artery as test methods. Study 2 uses alternatively calibrated pressure waves as reference method and alternatively calibrated distension waves and internally calibrated applanation tonometer readings as test methods.

Results: In study 1, pulse pressure from internally calibrated tonometer readings was $10.2 \pm 14.3 \mathrm{mmHg}$ lower and pulse pressure from alternatively calibrated pressure waves was $1.8 \pm 5.2 \mathrm{mmHg}$ higher than invasive pulse pressure. Pulse pressure from calibrated distension waves was $3.4 \pm 6.9 \mathrm{mmHg}$ lower than pulse pressure from alternatively calibrated pressure waves. According to British Hypertension Society criteria, pulse pressure from the internally calibrated tonometer got grade $D$, pulse pressure from alternatively calibrated pressure waves got grade A. Pulse pressure from calibrated distension waves got grade $\mathrm{B}$ when alternatively calibrated pressure waves were used as reference method.

Conclusions: Pulse pressure obtained from alternatively calibrated tonometerderived pressure waves and echo-tracking-derived distension waves show good accuracy. Accuracy of pulse pressure from internally calibrated applanation tonometer readings at the carotid artery is poor. 


\section{Introduction}

Systolic (SBP) and diastolic blood pressure (DBP) are determined by mean arterial pressure (MAP) and the pulse pressure oscillating around the MAP. ${ }^{1}$ In contrast to MAP, ${ }^{2}$ pulse pressure is not constant throughout the large artery tree. It increases centrifugally. ${ }^{1,3}$ But this pulse pressure amplification might be attenuated and even lost by early reflected pulse waves due to stiffening of arteries and/or by more proximal reflection sites. ${ }^{1,3}$ As a consequence, use of the pulse pressure obtained at one arterial site as surrogate of the pulse pressure at another arterial site might be erroneous. In recent years interest in pulse pressure has increased ${ }^{4}$ since a high brachial artery pulse pressure (PP) has been recognized as an independent risk factor for cardiovascular morbidity and mortality. ${ }^{5-14}$ It is likely that pulse pressure at other arterial sites than the brachial artery, i.e. the ascending aorta, may show a stronger association with cardiovascular events.

Applanation tonometry has been proposed to assess local arterial pulse pressure. It allows non-invasive recording of the arterial pressure waveform and magnitude in both central and peripheral arteries. ${ }^{15,16}$ This technique provides pressure waves, being almost identical to those obtained intraarterially..$^{17}$ However, several authors are convinced that the magnitude of the pulse pressure obtained by this internally calibrated applanation tonometry is unreliable. ${ }^{18}$ Kelly and Fitchett have proposed an alternative calibration of the tonometer pressure waves ${ }^{19}$ : at the reference artery (i.e. brachial artery) peak and nadir of the pressure wave are assigned systolic and diastolic pressures determined by a conventional method (i.e. sphygmomanometry). The mean pressure is calculated from numeric integral of the calibrated pressure wave. With assignment of the same mean and diastolic pressures to the target artery (i.e. carotid artery) the pressure wave at the target artery is calibrated throughout the cardiac cycle. This calibration procedure is based on the observation that mean blood pressure is constant throughout the large artery tree and that diastolic pressure does not change substantially ${ }^{20,21}$ and might improve assessment of local pulse pressure. Pauca et $\mathrm{al}^{2}$ showed that the difference between MAP and DBP (MAP-DBP) was only $0.2 \mathrm{mmHg}$ larger in the radial artery than in the ascending aorta.

Applanation tonometry cannot be applied to all subjects and at all arterial sites. ${ }^{21}$ It requires a stiff or bony structure to flatten the artery wall and a lean skin to avoid cushioning of the pressure pulse. In obese subjects applanation tonometry often is inaccurate at a majority of arterial sites. In lean subjects good waveforms can be easily obtained at the radial artery, but in a substantial number of subjects applanation tonometry is not reliable at the femoral artery. To overcome this problem use of a transfer function has been proposed. Since the use of a universal transfer function appears limited to the upper limb, only carotid artery and ascending aorta pulse pressure can be assessed by this latter technique. ${ }^{21}$ 
In contrast to the pressure waves obtained by applanation tonometry, arterial distension waves from echo-tracking devices ${ }^{22}$ can be obtained accurately at more arterial sites and also in a majority of obese subjects. Assessment of blood pressure based on calibrated arterial distension waves has been attempted in the past ${ }^{23,24}$ but failed because of lack of accurate arterial distension registration. Echo-tracking devices, recently developed have shown high accuracy and can measure arterial distension with an error less than $5 \mu \mathrm{m} .{ }^{22}$ If assessment of local pulse pressure by calibrated distension waves is accurate, this method might provide an alternative, which can be applied to a larger part of the population, and to more arterial sites than applanation tonometry.

To investigate the accuracy of pulse pressure directly obtained from the internally calibrated tonometer signal and the pulse pressure obtained by alternatively calibrated tonometer pressure waveforms (PWF) as proposed by Kelly and Fitchett, study 1 compares the internally calibrated tonometer-derived (PPtono) and PWF-calibrated pulse pressure (PPpwf) at the right common carotid artery (CCA) with the pulse pressure obtained intra-arterially in the ascending aorta (PPaorta) at the branch of the right CCA.

Invasive blood pressure recordings can only be obtained in a limited number of subjects and are not suitable for daily practice. Therefore, to investigate the accuracy of the pulse pressure obtained by alternatively calibrated arterial distension waves (DWF), study 2 compares DWF-calibrated pulse pressure (PPdwf) with internally calibrated tonometer (PPtono) and PWF-calibrated pulse pressures (PPpwf) at the CCA in a large population sample.

\section{Study designs and methods}

The 2 studies were approved by the local ethics committees and written informed consent was obtained from all subjects.

Study 1. Patients, who underwent a coronary artery catheterisation, entered the study. Using radioscopy a 6-French pig tail catheter (Bard, Galway, Ireland) was placed in the ascending aorta at the presumed branching off of the right $\mathrm{CCA}$. The catheter was connected to a disposable pressure monitor kit with high pressure line (Becton and Dickinson, Singapore, Singapore). The pressure signals were amplified (Mingograph 7, Siemens-Elema, Stockholm, Sweden) and digitized at a sample frequency of $200 \mathrm{~Hz}$ with resolution less than 0.15 $\mathrm{mmHg}$. Digitized intra-arterial blood pressure recordings were stored on hard disk for off-line analysis with customized software. PPaorta was calculated beat-to-beat as the difference between the systolic and diastolic blood pressure, being the difference between the peak and the nadir of each pressure wave. Simultaneously pulse pressure was measured by applanation tonometry at the right CCA. The output of the tonometer (Micro-Tip pressure transducer Model SPT-301, Millar Instruments, Houston, Texas, USA) was connected to the transducer control unit (Model TC-510, Millar Instruments, Houston, Texas, 
USA) for on-line internal calibration. Tonometer tracings were further amplified, digitized and stored on hard disk for off-line analysis using the same equipment and methods as for the intra-arterial pressure tracings. PPtono was calculated beat-to-beat as the difference between the pressures registered by the internally calibrated tonometer at peak and the nadir of each pressure wave, respectively. PPpwf was obtained by alternative calibration of the tonometer pressure wave on the pressure wave of the ascending aorta. PPpwf data are mean of at least 6 heartbeats.

Study 2. In 100 subjects from a random population sample ${ }^{25}$ brachial artery and CCA pressure and distension waves were obtained using applanation tonometry and echo-tracking (Ultramark V, ATL, Bothell, Washington, USA; combined with Wall Track System, Pie Medical, Maastricht, The Netherlands), respectively. Tonometer readings were obtained with the same equipment as in study 1 except for the signal amplifier (BAP 001, Simonsen \& Weel, Albertslund, Denmark). Tonometry and echo-tracking were done consecutively at the same CCA and brachial artery. Simultaneously with tonometer and echo-tracking measurements at the CCA, blood pressure was measured at the brachial artery with a semi-automated device (Dinamap, Critikon, Tampa, Florida, USA). Brachial artery pulse pressure was calculated as Dinamap systolic minus diastolic blood pressure. PPtono was calculated as in study 1 . PPpwf and PPdwf at the CCA were obtained from calibration of the PWF and DWF on the respective brachial artery waveforms. Data are means of at least 8 heartbeats.

Alternative calibration procedure according to Kelly and Fitchett ${ }^{19}$. This procedure assumes MAP minus DBP constant throughout the large artery tree. The pulse pressure at the target artery (PPtar) is calculated from the pulse pressure at the reference artery (PPref) and the $\mathrm{K}$ factor at target and reference arteries (Ktar and Kref, resp.) by the formula:

PPtar $=$ PPref $x$ Kref/Ktar

The calculation of the $K$ factor is shown in Figure $1: K=A / P .{ }^{26}$

This alternative calibration procedure can be employed to obtain the pulse pressure using the pressure waveform (PPpwf) as well as the arterial distension waveform (PPdwf).

Statistical analysis. Demographic data are shown as number or as mean \pm SD. Methods were compared according to the American Association for the Advancement of Medical Instrumentation (AAMI) ${ }^{27}$ and British Hypertension Society $(\mathrm{BHS})^{28}$ criteria for the evaluation of blood pressure measuring devices. Bland and Altman plots, ${ }^{29}$ and Pearson correlation were used. The influence of age, body mass index (BMI), gender, mean arterial pressure and pulse pressure on the difference in pulse pressure between methods was calculated using stepwise linear regression analysis. If a factor was not significant, the factor was dropped from the model. Statistical significance was set at $p<0.05$. 


\section{Results}

Subjects' characteristics are shown in Table 1. Pulse pressures and differences in pulse pressure between test and reference methods are shown in Table 2 and in Bland and Altman scatterplots (Figures 2-3). The effect of age, gender, $\mathrm{BMI}, \mathrm{MAP}$ and pulse pressure on the differences in pulse pressure between methods are shown in Table 3. Only statistical significant associations are tabulated.

Study 1 compares pulse pressure measured invasively at the ascending aorta (reference method) with pulse pressure at the CCA measured with applanation tonometry (test method). Evaluable readings of both techniques were obtained in 19 patients aged 40 through 79 years. In 13 patients measurements were done before and in 6 after administration of nitroglycerin. None of the patients had a hemodynamically significant carotid artery stenosis as measured with Duplex echo/Doppler. According to AAMI criteria for invasive and beat-to-beat 
measurements, comparison was done on 133 measurements (19 subjects with 7 heartbeats each) for PPaorta and PPtono.

PPtono was on average $18.5 \%$ lower than PPaorta and did not correlate well with the reference method. PPpwf was on average 3.3\% higher and correlated very well with PPaorta. The standard deviation of the difference with PPaorta was for PPpw 2.75 times smaller than for PPtono (Table 2 and Figures 2a and $2 b)$. The difference between PPtono and PPaorta was negatively related with age, MAP, BMI and PP (Table 3). The difference between PPpwf and PPaorta was positively related with age, MAP and PPpwf, but not with PPaorta. As only 2 subjects were female in study 1 , the influence of gender was not tested.

Study 2 compares pulse pressure from calibrated distension waveforms (PPdwf) with that from calibrated pressure waveforms (PPpwf). Evaluable readings of both techniques were obtained in 100 subjects aged 12 through 77 y (Table 1). As in study 1 PPpwf was the most accurate noninvasive method, PPpwf was used as reference method in study 2. PPtono was $37.4 \%$ lower than PPpwf and did not correlate with reference PPpwf. PPdwf was on average 9.3\% lower than PPpwf and correlated well with PPpwf (Table 2). The standard deviation of the difference with PPpwf was for PPdwf 2.4 times smaller than for PPtono (Table 2 and Figures $3 a$ and $3 b$ ). By correcting each PPpwf for the systematic difference of $1.8 \mathrm{mmHg}$ from invasive pulse pressure in study 1 , the difference of PPdwf from invasive pulse pressure (PPdwf-PPaorta) was roughly estimated. Gender, age, BMI and MAP did not influence the difference in pulse pressure between methods (Table 3). The differences of both PPtono and PPdwf from reference method were negatively related with PPpwf. 
Table 4 shows the accuracy of the test methods versus the standard method according to the BHS grading criteria. In studies 1 and 2 PPtono got the lowest grade of accuracy (D). In study 1 PPpwf obtained the best grade of accuracy (A). In study 2, with PPpwf as reference method PPdwf got grade B of good accuracy. After correction of each PPpwf value in study 2 for the systematic error $(1.8 \mathrm{mmHg})$ of PPpwf versus PPaorta in study 1, PPdwf met grade A of accuracy.

\section{Discussion}

No standard criteria for the evaluation of local pulse pressure assessment exist. Although developed for the evaluation of SBP and DBP, the AAMI and $\mathrm{BHS}$ criteria for the evaluation of pressure measuring devices can be applied to pulse pressure as well.

As it has been shown that pulse pressure in the common carotid artery is identical to the ascending aorta at the branching off of the CCA,${ }^{18}$ PPaorta can be used as surrogate for the real pulse pressure in the CCA.

In both of the present studies, PPtono was not related to reference pulse pressure. On average PPtono largely underestimated the invasive reference pulse pressure. In addition, Bland-Altman analysis showed that PPtono could also overestimate the pulse pressure in a substantial number of assessments. Both the systematic error and the large variation indicate a poor agreement and precision of the pulse pressure obtained directly from the internally calibrated tonometer in our hands. Although there is no direct guide to indicate optimal applanation, it is felt that this condition occurs when the operator adjusts the hold-down force so that the waveform has a stable baseline, maximum amplitude and a 'reasonable' configuration. ${ }^{18}$ Since there is substantial soft tissue between the external probe tip and the carotid artery in situ, it is more difficult to ascertain when this optimal state is achieved. ${ }^{18}$ Therefore, It has been argued that applanation tonometry needs a well-skilled investigator. All measurements in each study were done by 1 investigator, but the investigator differed between the 2 studies. The 2 investigators obtained independently similar poor results for PPtono: the mean difference and standard deviation of the difference between PPtono and PPpwf were comparable in study 1 and study 2. As presumed by other investigators, ${ }^{18}$ we conclude that also in our hands pulse pressures at the CCA obtained from internally calibrated applanation tonometry are inaccurate. In contrast to PPtono, pulse pressures at the CCA assessed by the alternatively calibrated tonometer pressure waveforms (PPpwf) did correlate very well with PPaorta. There was on average a slight $(1.8 \mathrm{mmHg})$ but acceptable overestimation of the pulse pressure with a small standard deviation of this difference in the Bland-Altman analysis. This deviation from reference method was largely within the acceptability limits of the AAMI criteria $(5 \pm 8 \mathrm{mmHg})$. In addition, according to the BHS criteria, PPpwf obtained the best grade of accuracy. The difference 
between PPpwf and PPaorta was influenced by age, MAP and the level of the pulse pressure, all conditions for which the applanation pressure has to be high to flatten the artery wall and to obtain a good pressure wave. Whether in these conditions inertia of the hand may influences the results is not clear. To investigate this, pencil applanation tonometry held by hand (as used in the present study) should be compared with applanation tonometry using a micromanipulator or a wristband. Alternatively, it cannot be excluded that aortic pulse pressure measured invasively with a fluid filled catheter may slightly underestimate real pulse pressure. Data of the present study 1 show that assessment of the pulse pressure by alternatively calibrated tonometer pressure waveforms is accurate in the population studied. It also demonstrates that accurate PPpwf can be obtained despite an inaccurate PPtono by scaling the tonometer pressure waveform.

As a consequence of results of study 1, in study 2 PPpwf was used as noninvasive reference method. Data of study 2 confirm the inaccuracy of PPtono in our hands. In contrast and despite presumed confounding factors like viscoelasticity and non-linearity of pressure-distension relationship of the arterial wall, PPdwf at the CCA correlated well with PPpwf and was on average 3.4 $\mathrm{mmHg}$ lower than PPpwf. Assuming a generalized overestimation of the invasive pulse pressure with $1.8 \mathrm{mmHg}$ by PPpwf in study 1, PPdwf may on average underestimate invasive pulse pressure with $1.6 \mathrm{mmHg}$, which is a systematic error from invasive pulse pressure in magnitude comparable with the error of PPpwf in study 1. Bland-Altman analysis also showed for PPdwf a standard deviation in difference from PPpwf less than half that of PPtono, but slightly higher than the standard deviation in difference between PPaorta and PPpwf in study 1.

In contrast to the simultaneous measurement of PPaorta and PPpwf in study 1, in study 2, for technical reasons it was not possible to assess PPdwf and PPpwf simultaneously. The consecutive measurement of PPdwf and PPpwf is expected to increase the variation in difference between PPdwf and PPpwf due to short term spontaneous change in pulse pressure. In study 1 the short term variation in pulse pressure was $2.8 \pm 4.8 \mathrm{mmHg}$ (data not shown in results). In addition, correlation coefficient of PPdwf with invasive pulse pressure is likely to be higher than the +0.85 correlation coefficient between PPdwf and PPpwf. The difference in pulse pressure between PPdwf and PPpwf was not influenced by age, gender, BMI and MAP, but was influenced by PPpwf. The slope was $0.29 \mathrm{mmHg} / \mathrm{y}$. As the effect of pulse pressure on the difference between PPpwf and PPaorta is $+0.12 \mathrm{mmHg} / \mathrm{y}$ in study 1 , it can be assumed that in study 2 about $40 \%(0.12 / 0.29)$ of the influence of PPpwf on the difference between PPdwf and PPpwf is caused by an error in the estimate of PPpwf and about $60 \%$ can be attributed to an error in the estimate of PPdwf .

Except for PPtono, the above mentioned data of mean and standard error of difference between test and reference method are largely within the AAMI criteria of acceptability. In addition, according to the BHS criteria, PPdwf 
obtained the B grade of good accuracy. This grading can be influenced by a systematic difference between methods. ${ }^{27}$ After correction of each PPpwf for the systematic difference of $1.8 \mathrm{mmHg}$ from invasive pulse pressure in study 1 , PPdwf met the A criteria of excellent accuracy. These data show that assessment of pulse pressure by calibrated distension waves is acceptable for the assessment of local pulse pressure at the CCA in a random population. It is expected that this calibration procedure is also applicable to other arterial sites. As distension waves can be obtained in subjects and at arterial sites where applanation tonometry and transfer function are not reliable or not possible for technical reasons, assessment of PPdwf is a valuable asset in the assessment of local pulse pressure and a good alternative for PPpwf.

In conclusion, the present study shows that (i) pulse pressures from the alternatively calibrated tonometer pressure waves and from the alternatively calibrated echo-tracking arterial distension waves show good to excellent agreement and precision in the population studied. (ii) The accuracy of the two calibration methods is depending on the pulse pressure. Accuracy in patients with high pulse pressure $(>80 \mathrm{mmHg}$ ) has still to be established. (iii) In our hands agreement and precision of pulse pressures obtained directly from internally calibrated applanation tonometry at the CCA is poor and unacceptable.

\section{Acknowledgements}

The study was supported by the Cardiovascular Research Institute Maastricht. The expert technical assistance of $\mathrm{mr}$ J. Willigers BSc, dr I. de Ploeg, $\mathrm{mr}$ G. Wijnands, $\mathrm{mr} \mathrm{J}$. Dacier and $\mathrm{mrs} \mathrm{M}$. Knippenberg is gratefully acknowledged. The expert assistance of drs B. Van Baelen for statistics is also acknowledged. 
1. Safar ME, London GM. The arterial system in human hypertension. In: Swales JD (editor): Textbook of hypertension. London: Blackwell Scientific Publications; 1994, pp. 85-102

2. Pauca AL, Wallenhaupt SL, Kon ND, Tucker WY. Does radial artery pressure accurately reflect aortic pressure? Chest 1992; 102:1193-8

3. Nichols WW, O'Rourke M. McDonald's blood flow in arteries. Theoretical, experimental and clinical principles. 4th ed. London-Sydney-Auckland: Arnold; 1998, pp. 170-222 and 347-76

4. Black HR, Kuller LH, O'Rourke MF, Weber MA, Alderman MH, Benetos A, et al. The first report of the Systolic and Pulse Pressure (SYPP) Working Group. J Hypertens 1999; 17(suppl5):S3-S14

5. Darne B, Girerd X, Safar M, Cambien F, Guize L. Pulsatile versus steady component of blood pressure: a cross-sectional analysis and a prospective analysis on cardiovascular mortality. Hypertension 1989; 13:392-400

6. Madhavan S, Ooi WL, Cohen $\mathrm{H}$, Alderman $\mathrm{MH}$. Relation of pulse pressure and blood pressure reduction to the incidence of myocardial infarction. Hypertension 1994; 23:395-401

7. Fang J, Madhavan S, Cohen $\mathrm{H}$, Alderman $\mathrm{MH}$. Measures of blood pressure and myocardial infarction in treated hypertensive patients. J Hypertens 1995; 13:413-9

8. Benetos A, Safar M, Rudnichi A, Smulyan H, Richard JL, Ducimetiere P, et al. Pulse pressure: a predictor of long-term cardiovascular mortality in a French male population. Hypertension 1997; 30:1410-5

9. Mitchell GF, Moye LM, Braunwald E, Rouleau J-L, Bernstein V, Geltman EM, et al. Sphygmomanometrically determined pulse pressure is a powerful independent predictor of recurrent events after myocardial infarction in patients with impaired left ventricular function. Circulation 1997; 96:4254-60

10. Verdecchia P, Schillaci G, Borgioni C, Ciucci A, Pede S, Porcellati C. Ambulatory pulse pressure. A potent predictor of total cardiovascular risk in hypertension. Hypertension 1998; 32:983-8

11.Chae CU, Pfeffer MA, Glynn RJ, Mitchell GF, Taylor JO, Hennekens CH. Increased pulse pressure and risk of heart failure in the elderly. JAMA 1999; $281: 634-9$

12.Franklin SS, Khan SA, Wong ND, Larson MG, Levy D. Is pulse pressure useful in predicting risk for coronary heart disease? The Framingham Heart Study. Circulation 1999; 100:354-60

13. Millar JA, Lever AF, Burke V. Pulse pressure as a risk factor for cardiovascular events in the MRC mild hypertension trial. J Hypertens 1999; 17:1065-72

14.Staessen JA, Gasowski J, Wang JG, Thijs L, Den Hond E, Boissel JP, et al. Risks of untreated and treated isolated systolic hypertension in the elderly: meta-analysis of outcome trials. Lancet 2000; 355:865-72

15.London G, Guerin A, Pannier B, Marchais S, Benetos A, Safar M. 
Increased systolic pressure in chronic uremia: role of arterial wave reflections. Hypertension 1992; 20:10-9

16.Benetos A, Laurent S, Hoeks AP, Boutouyrie PH, Safar ME. Arterial alterations with aging and high blood pressure. A noninvasive study of carotid and femoral arteries. Arterioscler Thromb 1993; 13:90-7

17.Kelly R, Hayward C, Ganis J, Daley J, Avolio A, O' Rourke M. Non-invasive registration of the arterial pressure pulse waveform using high-fidelity applanation tonometry. J Vasc Med Biol 1989; 3:142-9

18.Chen C-H, Ting C-T, Nussbacher A, Nevo E, Kass DA, Pak P, et al. Validation of carotid artery tonometry as a means of estimating augmentation index of ascending aortic pressure. Hypertension 1996; 27:168-75

19.Kelly R, Fitchett D. Noninvasive determination of aortic input impedance and external left ventricular power output: a validation and repeatability study of a new technique. J Am Coll Cardiol 1992; 20:952-963

20.Milnor WR. The normal hemodynamic state. In: Milnor WR (editor): Hemodynamics. Baltimore, Md: Williams and Wilkins; 1982, pp. 132-56

21.Nichols WW, O'Rourke M. McDonald's blood flow in arteries. Theoretical, experimental and clinical principles. $4^{\text {th }}$ ed. London-Sydney-Auckland: Arnold; 1998, pp. 453-76

22. Hoeks APG, Brands PJ, Smeets FAM, Reneman RS. Assessment of the distensibility of superficial arteries. Ultrasound Med Biol 1990; 16:121-8

23.Correll RW. Theoretical analysis and preliminary development of an indirect blood pressure recording system. M.S. Thesis, M.I.T., Cambridge, MA: 1978

24.Ghista DN, Jayaraman G, Sandler H. Analysis for the noninvasive determination of arterial properties and for the transcutaneous continuous monitoring of arterial blood pressure. Med Biol Engng Comput 1978; 16:715-26

25.Van der Heijden-Spek JJ, Staessen JA, Fagard RH, Hoeks AP, Struijker Boudier HA, Van Bortel LM. The effect of age on brachial artery properties differs from the aorta and is gender dependent: a population study. Hypertension 2000; 35:637-42

26. Hansen $\mathrm{KW}$, Orskov $\mathrm{H}$. A plea for consistent reliability in ambulatory blood pressure monitors: a reminder. J Hypertens 1992; 10:1313-1315

27.White WB, Berson AS, Robbins C, Jamieson MJ, Prisant M, Roccella E, Sheps SG. National standard for measurement of resting and ambulatory blood pressures with automated sphygmomanometers. Hypertension 1993; 21:504-9

28.O'Brien E, Petrie J, Littler W, de Swiet M, Padfield PL, Altman DG, et al. The British Hypertension Society protocol for the evaluation of blood pressure devices. J Hypertens 1993; 11(Suppl 2):S43-S62

29.Bland JM, Altman DG. Statistical methods for assessing agreement between two methods of clinical measurement. Lancet 1986; i:307-10 
Chapter 4

Carotid and Femoral Artery Stiffness in Relation to Three Candidate Genes in a White Population

E.J. Balkestein

J.A. Staessen

J-G Wang

J.J. van der Heijden-Spek

L.M. Van Bortel

C. Barlassina

G. Bianchi

E. Brand

S-M Herrmann

H.A. Struijker Boudier

Previously published in: Hypertension 2001; volume 38; pp 1190-1197 
Abstract-Different genetic polymorphisms influence cardio-vascular disease. We recently discovered a relationship between the intima-media thickness of the muscular femoral artery, but not the elastic common carotid artery, and the combined angiotensin-converting enzyme (ACE, I/D), $\alpha$-adducin $(A D D$, Gly460Trp) and aldosterone synthase (AS, C-344T) gene polymorphisms. To investigate the relationship between these polymorphisms and functional properties of the carotid artery and femoral artery, a sample of 756 subjects enrolled in a population study were genotyped for the presence of the $A C E D$, $\alpha$-adducin 460Trp and aldosterone synthase -344T alleles. Vessel wall properties were assessed using a vessel wall movement detector system in combination with applanation tonometry. Statistical analysis allowed for confounders and interaction among genes.

Cross-sectional compliance of the common carotid artery was negatively associated with the ACE $D$ allele. ACE I/ versus ACE DD homozygotes differed, expressed as a percentage of the population mean, $7.0 \%(95 \% \mathrm{Cl}: 1.6$ - 12.4; $\mathrm{p}<0.01)$. In multiple-gene analysis, ACE $D D$ subjects also deviated significantly from the population mean for the distensibility coefficient of the common carotid artery, when carrying the $A S / T$ allele: $-5.5 \%(95 \% \mathrm{Cl}:-9.3$ to $1.7 ; \mathrm{p}<0.01$ ), without a change in cross-sectional compliance. ACE DD subjects, when homozygote for $\alpha$-adducin Gly460 had a lower femoral crosssectional compliance: $-10.4 \%(95 \% \mathrm{Cl}:-1.9$ to $-18.9 ; \mathrm{p}<0.03)$ and a lower distensibility: $-9.7 \%(95 \% \mathrm{Cl}:-2.1$ to $-17.3 ; \mathrm{p}<0.02)$ compared to the population mean.

These data show that functional large artery properties are influenced by the $A C E$ I/D polymorphism. Cross-sectional compliance and distensibility coefficients are influenced by the $A C E$ I/D genotype, but this influence depends on the vascular territory and genetic background. 
Numerous studies have examined the effects of different genetic polymorphisms on cardiovascular disease, with emphasis on the genes coding for components of the renin angiotensin aldosterone system (RAAS). We recently observed that the angiotensin-converting enzyme (ACE) insertion/deletion (I/D) polymorphism $(A C E I / D)$ was related to increased intima-medial thickness of the large muscular femoral artery and this relationship was strongest when the $\alpha$-adducin 460Trp allele or the aldosterone synthase $-344 T$ allele was present as well. The ACE I/D polymorphism has previously been studied in relation to other manifestations of cardiovascular diseases such as myocardial infarction, ${ }^{1}$ atherosclerosis, ${ }^{2-5}$ left ventricular hypertrophy, ${ }^{6-8}$ and hypertension. ${ }^{9-11}$ Only few studies have investigated the effect of candidate genes on more specific cardiovascular phenotypes, such as large artery function. Benetos and colleagues ${ }^{12-14}$ studied pulse wave velocity (PWV), a marker of aortic stiffness, ${ }^{15}$ in relation to $A C E$ $I / D$, angiotensin-II type 1 receptor and aldosterone synthase gene polymorphisms. In hypertensive patients, a positive association with PWV was found for the angiotensin II type 1 receptor (A1166C), in both patients with and without treatment ${ }^{12,13,16}$ and for $A C E I / D^{13}$ and aldosterone synthase $C-344 T$ in treated hypertensive subjects. ${ }^{14}$ In a recent study, Benetos and colleagues ${ }^{16}$ did not confirm the relationship between the aldosterone synthase gene and PWV in untreated hypertensives, nor did they find a relationship with the $A C E$ $I / D$ or two angiotensinogen gene (AGT) polymorphisms (T174M, M235T). Two variants of the angiotensin II type 1 receptor gene, $A-153 G$ and $A 1166 C$ were, however, reported to be related to PWV, whereas in normotensive controls no association for the A1166C variant has been observed. ${ }^{13}$ Taniwaki et al. ${ }^{17}$ studied PWV and local carotid stiffness in patients with type II diabetes and age-matched controls. In type II diabetics both PWV and carotid stiffness were negatively associated with the I allele of the ACE I/D polymorphism. However, like Benetos et $\mathrm{al}^{13}{ }^{13}$ no association was found in healthy controls. In the present study we investigated the single gene effects and the interactions of the $A C E I / D, \alpha$-adducin and aldosterone synthase gene polymorphisms on arterial function of the elastic common carotid artery and the muscular femoral artery in a general population.

\section{METHODS}

\section{Study population}

The Flemish Study on Environment, Genes and Health Outcomes (FLEMENGHO) started in 1985. The Ethics Committee of the University of Leuven approved its protocol. From August 1985 until November 1990, a random sample of the households living in a geographically defined area of Northern Belgium was recruited. ${ }^{18}$ To further investigate the role of genetic factors, from June 1996 until January 1999, the study population was enlarged with nuclear families including children who were at least 10 years old, using 
the former participants as index persons. ${ }^{18}$ The participants or their parents gave informed consent. The participation rate among all subjects contacted was $64.3 \%$. The study population for which all significant covariables and outcome variables were present, consisted of 756 persons.

Measurements

Before the participants were examined at our field centre, they refrained from smoking, heavy exercise, and drinking alcohol or caffeine containing beverages for $\geq 3$ hours. Their blood pressure was measured 5 times consecutively after they had rested for 5 minutes and were sitting. Hypertension was diagnosed if the average of the 5 blood pressure readings was $\geq 140 \mathrm{~mm} \mathrm{Hg}$ systolic or $\geq 90 \mathrm{~mm} \mathrm{Hg}$ diastolic, or when the subjects were on antihypertensive medication. A venous blood sample was obtained for measurement of serum lipids and determination of genotypes.

\section{Vascular measurements}

All subjects were examined in a quiet room after 15 minutes of supine rest.

Two observers (J.J. van der H.-S. and E.J.B.) performed measurements at the common carotid artery $2 \mathrm{~cm}$ proximal from the bulb and measurements at the femoral site $1 \mathrm{~cm}$ proximal to the bifurcation into the profound and superficial branches. To examine vascular wall properties of the arteries, a pulsed ultrasound echo-tracking system was used, which is based on the RF-signal and which was described and validated earlier by Hoeks et al. ${ }^{19}$ Diameter and diameter changes throughout the cardiac cycles were measured on average for 15 heartbeats and the mean of these measurements was taken as the subject's reading. Local pulse pressure was calculated after assessing the tonometric signal at the artery of interest with a pencil-shaped probe (Millar, Houston, USA) ${ }^{20}$ by calibration of the pulse wave contour with diastolic and mean arterial pressure, which is assumed to be equal over the arterial tree. ${ }^{21}$ The mean of on average 15 heartbeats, was taken as the subject's reading. If tonometry was not possible, due to obesity or the presence of arterial plaque, the vessel wall movement contour was used as a surrogate for the tonometrically derived pulse pressure contour with calibration as described above. Recently, this method has been described in detail. ${ }^{22}$

Blood pressure and heart rate were measured every three minutes with a semi-automated device (Dinamap 845, Critikon, Tampa, Florida USA) and the within-subject of the vascular measurements was used for descriptive analysis and calibration of local pulse pressure. Distensibility coefficient (DC) was calculated from the diastolic cross sectional area $(A)$ and change in cross sectional area $(\Delta A)$ and local pulse pressure $(\Delta P)$ with the formula:

$\mathrm{DC}=(\Delta \mathrm{A} / \mathrm{A}) / \Delta \mathrm{P}$.

A and $\Delta A$ were calculated as $A=\pi \bullet(D / 2)^{2}$ and $\Delta A=\pi \bullet((D+\Delta D) / 2)^{2}-\pi \bullet(D / 2)^{2}$. Cross sectional compliance $(\mathrm{CC})$ was calculated as: $\mathrm{CC}=\Delta \mathrm{A} / \Delta \mathrm{P}{ }^{23}$ 
Determination of genotypes

Genotyping of ACE I/D polymorphism

The $A C E I / D$ polymorphism was detected as previously described by Lindpaintner et al. ${ }^{24}$ All samples genotyped as $D D$ underwent a second polymerase chain reaction using insertion-specific primers. Polymerase chain reaction (PCR) conditions were as before except for an annealing temperature of $67^{\circ} \mathrm{C}$.

The sense primer was 5' TGGGACCACAGCGCCCGCCACTAC 3', the antisense primer was 5' TCGCCAGCCCTCCCATGCCCATAA 3'.

Genotyping of Gly460Trp $\alpha$-adducin polymorphism

Allelic discrimination of the Gly460Trp $\alpha$-adducin polymorphism was carried out using a 5' nuclease assay ${ }^{25}$ on an ABI Prism 7700 apparatus (Perkin Elmer, Norwalk, CT) as described by Cusi et al. ${ }^{26}$ The forward and reverse primers and the 460Gly and 460Trp probes employed in the TAQMan assay were 5'-CGTCCACACCTTAGTCTTCGACTT-3',

5'-GGAGAAGACAAGATGGCTGAACTC-3', 5'-FAMTTCCATTCTGCCCTTCCTCGGA-TAMRA-3' and 5'-TETTTCCATTCTGCCATTCCTCGGAA-TAMRA-3', respectively.

Genotyping of CYP11B2 polymorphism

For determination of the $C-344 T$ aldosterone synthase gene variants, PCR and subsequent genotyping were performed as described by Brand et al. ${ }^{27}$

Statistical analysis

For statistical analysis we used SAS version 8.1 (SAS Institute, Cary, NC). Significant covariables for cross-sectional compliance and distensibility coefficient for the common carotid and femoral artery were traced by stepwise linear regression. In addition, potentially important covariables were forced into to the models regardless of statistical significance. In multiple linear regression, the genotypes were first represented by dummy variables using the deviation from mean coding approach, ${ }^{28}$ which does not imply any genetic hypothesis. In single-gene analyses in which we tested independent hypotheses, we adjusted $\alpha$-levels and confidence intervals (Cls) for multiple testing using Bonferroni's method. ${ }^{29}$ Because family members are more likely to share identical alleles than randomly selected subjects, we performed the analysis using generalized estimating equations to account for the possible non-independence of vessel wall properties within families. ${ }^{30,31} P<0.05$ were considered significant for the analysis of interaction among genes. 


\section{RESULTS}

Characteristics of the participants

The 756 participants included 379 men (50.1\%) and 377 (49.1\%) women (Table 1). The sample consisted of 272 subjects belonging to households or nuclear families with $\geq 1$ related individual (82 families), 33 spouse-spouse pairs (33 families) and 418 single individuals. Age ranged from 12 to 79 years. 154 subjects $(20.4 \%)$ were hypertensive and of those, 49 were receiving antihypertensive treatment $(31.8 \%)$. One hundred twenty male participants (31.7\%) reported current smoking and $192(50.7 \%)$ reported intake of alcohol. For female participants, $107(28.4 \%)$ and $91(24.1 \%)$, respectively. Ninety-two female subjects (24.4\%) were post-menopausal, and 32 of pre-menopausal women $(11.2 \%)$ used oral contraceptives. The characteristics of the carotid and femoral arteries by gender and age are presented in Figure 1. 


\section{Single-gene effects}

Genotype frequencies of the ACE I/D $(P=0.06), \alpha$-adducin Gly460Trp $(P=0.48)$, and aldosterone synthase $C$-344T $(P=0.17)$ polymorphisms did not significantly deviate from Hardy-Weinberg equilibrium.

In stepwise regression analysis, cross-sectional compliance, distensibility coefficient and diameter of the carotid and femoral arteries were significantly correlated with age, with the exception of femoral artery compliance (Table 2). Other covariables which entered the models on $\geq 1$ occasions were gender, body-mass index, mean arterial pressure, current treatment for hypertension, current smoking and observer. With cumulative adjustment for all these covariables we found a significant association between the cross-sectional compliance of the common carotid artery and the ACE I/D genotype (Figure 2). Cross-sectional compliance decreased with the number of $A C E D$ alleles. Indeed, compared with the population mean, ACE // subjects had a crosssectional compliance of, expressed as a percentage of the population mean, $3.9 \%(95 \% \mathrm{Cl}, 0.1 \%-7.7 \% ; P=0.04)$ higher. In contrast, in single-gene analyses, the cross-sectional compliance and distensibility coefficients of both the common carotid and femoral artery were not significantly associated with the $\alpha$-adducin or aldosterone synthase genotypes. 


\section{Multigene effects}

In multigene analyses, with adjustments for the same covariables as applied in the single-gene approach, we found significant differences in the arterial wall properties associated with the ACE DD genotype. The analysis showed that the influence of the ACE DD genotype depended on the vascular territory and individual genetic background. Indeed, compared with the population mean (expressed as percentage of the population mean), the diameter of the common carotid artery was significantly larger $(1.8 \%$; $95 \% \mathrm{Cl}, 0.1 \%-3.5 \%$; $P=0.03$ ) in the presence of the aldosterone synthase $-344 T$ allele (Figure 3 ). This increase in diameter was associated with a decreased distensibility of the common carotid artery in ACE DD homozygotes, who also carried the aldosterone synthase $-344 \mathrm{~T}$ allele $(-5.5 \%$ ' $95 \% \mathrm{Cl},-1.7 \%$ to $9.3 \%, P=0.005$ versus the population mean). However, in the latter subgroup, no change was observed in the cross-sectional compliance of the common carotid artery (Figure 3).

Furthermore, compared with the population mean (Figure 4), the crosssectional compliance of the femoral artery was significantly smaller in ACE DD subjects not carrying the $\alpha$-adducin 460 Trp allele $(-10.4 \% ; 95 \% \mathrm{Cl},-1.9 \%$ to $18.9 \% ; P=0.02)$. This was accompanied by a decrease in the distensibility coefficient of the femoral artery $(-9.7 \% ; 95 \% \mathrm{Cl},-2.1 \%$ to $-17.3 \% ; P=0.01$ versus the population mean), but not with a change in diameter (Figure 4). 


\section{Discussion}

This study shows that combinations of genetic polymorphisms of the ACE I/D, $\alpha$-adducin and the aldosterone synthase gene influence local arterial function. A single-gene effect was observed for the ACE I/D polymorphism on the compliance of the elastic common carotid artery. In multigene analysis, a significant interaction between ACE I/D and $\alpha$-adducin Gly460Trp was detected at the femoral artery. ACE $D D$ subjects homozygote for $\alpha$-adducin (G/yG/y) deviated significantly from the mean for both distensibility coefficient and cross-sectional compliance. With respect to the carotid artery interaction between the ACE I/D and the aldosterone synthase $C$-344T polymorphism were significant. ACE DD subjects carrying the aldosterone synthase $-344 T$ allele had a lower distensibility coefficient, with a larger diameter and no change in cross-sectional compliance.

Our finding of a single-gene effect on carotid artery stiffness in the general population is in contrast with previous observations on the influence of the $A C E$ I/D polymorphism in healthy subjects. ${ }^{13,17}$ The variance of our data with those of Taniwaki et al. may be due to the exclusion in the latter study of hypertensives (systolic blood pressure $>160 \mathrm{mmHg}$ ), patients with a history of peripheral vascular disease, myocardial infarction, cerebrovascular disease and patients who used any medication. The same holds for the study of Benetos et al. ${ }^{13}$ who excluded subjects on the basis of a history or presence of lower-limb arterial disease, stroke, heart failure and blood pressures of systolic blood pressure $>145 \mathrm{mmHg}$ and diastolic blood pressure $>90 \mathrm{mmHg}$. Furthermore, the number $(\mathrm{n}=260$ and 128$)$ of subjects was much smaller than our study. Our data suggest that in a general population the ACE $D$ allele predisposes to a decreased compliance of elastic arteries. It remains to be explained why this effect was not observed in the more muscular femoral artery. Previous research has shown that the different structural bases of elastic and muscular arteries may have important implications for their adaptive behaviour. ${ }^{32}$

In our study population no single-gene effect was found for the aldosterone synthase gene polymorphism. Benetos et al. ${ }^{14}$ reported an increased PWV for the $C$-344 allele in 216 hypertensive patients, although this was not confirmed in their most recent study in 441 untreated hypertensives. ${ }^{16}$ There were clear differences in the experimental approach and populations studied by us and by Benetos et al. ${ }^{14,16}$ PWV is a general marker of arterial stiffness in essential hypertension, whereas in the present study local stiffness was measured. PWV may reflect other aspects of vascular structure and its adaptation in hypertension than we observe using our measurements of compliance of the carotid or femoral artery.

In previous studies, we ${ }^{33}$ and others ${ }^{9,34}$ showed that the interaction of various genes might provide a stronger basis for genetic determination of cardiovascular diseases than single-gene effects. In our previous work we showed the particular significance of such interactions between components of the RAAS and the $\alpha$-adducin Gly460Trp polymorphism. ${ }^{33}$ There are various 
potential physiological interactions between these systems. On the one hand, at the level of the kidney both the RAAS and $\alpha$-adducin contribute to sodium handling and volume homeostasis. ${ }^{35}$ At the vascular level, interactions are more complex and may depend on the vessel wall component that is involved. Vessel wall elasticity depends on vascular smooth muscle cell mass and tone as well as on the composition of extracellular matrix material. There are marked differences between various types of arteries with respect to the contribution of each of these components. Thus, gene-gene interactions may have a different outcome according to the type of artery studied.

In the present study we noted an interaction between aldosterone synthase gene and $A C E I / D$ polymorphisms at the level of the carotid artery. The occurrence of the aldosterone synthase $-344 T$ allele seems necessary to bring about the negative association with the ACE $D$ allele on distensibility of the common carotid artery. Our data are compatible with a decrease in distensibility due to an increase in diameter.

At the level of the femoral artery we noted a significant interaction between the -adducin 460Trp allele and the ACE I/D polymorphism. In a previous study we found that the presence of the 460Trp allele in combination with the ACE $D$ allele causes enhanced intima-media thickening of the muscular femoral artery (Balkestein E.J.M. et al, unpublished data, 2001). If this hypertrophy were primarily due to an increased vascular smooth muscle cell mass, it would lead to an increased distensibility of the vessel wall. On the other hand, an ACE D allele may have a more pronounced effect on extracellular matrix synthesis due to higher local levels of angiotensin II. ${ }^{36,37}$ This would result in a decreased distensibility of the femoral artery in ACE $D D$ persons lacking the $\alpha$-adducin 460Trp allele. The present data suggest that $\alpha$-adducin can override the increased femoral stiffness in $A C E D D$ subjects by increasing smooth muscle cell mass. Before such conclusions can be drawn more firmly, additional research should be performed on the mechanisms whereby $A C E$ and $\alpha$-adducin influence the structure and function of various components of the vessel wall.

In summary, gene-gene interactions between components of the RAAS and $\alpha$-adducin seem to play a role in large artery function and structure. Similarly, they contribute to the development of hypertension. The unravelling of the cellular mechanisms underlying these interactions poses a challenge for future hypertension research.

\section{Acknowledgements}

The FLEMENGHO Study was supported by research grants G.0174.97 and G.0291.98 from the Fonds voor Wetenschappelijk Onderzoek Vlaanderen (Brussels, Belgium) and by a special research grant from the Katholieke Universiteit Leuven (Onderzoekstoelage OT99/28). Nuclear families were recruited in the framework of the European Project on Genes in Hypertension, which is supported by the European Union (contract IC15-CT98-0329-EPOGH and QLG1-CT-2000-01137-EURNETGEN). The Flemish population study would not have been possible without the collaboration of the family physicians 
of the participants. The municipality Hechtel-Eksel (Belgium) provided logistic support. The authors acknowledge the expert assistance of Leszek Bieniaszewski MD, Rina Bollen, Lut De Pauw RN, Hilde Celis MD, Primoz Dolenc MD, Paul Drent RN, Dmitri Emelianov MD, Jerzy GÅsowski MD, Heng Fan, Lieve Gijsbers, Alida Hermans, Tatyana Kuznetsova MD, Tim Nawrot BSC, Lutgarde Thijs BSC, Yvette Toremans, Sylvia Van Hulle RN and Renilde Wolfs (Study Coordinating Centre, Leuven, Belgium). Genetic studies in Berlin, Germany, were supported by grants from the Deutsche Forschungsgemeinschaft to Eva Brand (BR 1589/1-1) and Stefan-Martin Herrmann (HE 2852/1-1) and by a grant from the Société Française d'Hypertension Artérielle to Eva Brand. Brigitte Egbers (Berlin) determined the aldosterone-synthase genotypes. 
1. Samani NK, Thompson JR, O'Toole L, Channer K, Woods KL. A metaanalysis of the association of the deletion allele of the angiotensionconverting enzyme gene with myocardial infarction. Circulation. 1996;94:708-712.

2. Hibi K, Ishigami T, Kimura K, Nakao M, Iwamoto T, Tamura K, Nemoto T, Shimizu T, Mochida Y, Ochiai H, Umemura S, Ishii M. Angiotensinconverting enzyme gene polymorphism adds risk for the severity of coronary atherosclerosis in smokers. Hypertension. 1997;30:574-579.

3. Olivieri O, Trabetti E, Grazioli S, Stranieri C, Friso S, Girelli D, Russo C, Pignatti PF, Mansueto G, Corrocher R. Genetic polymorphisms of the renin-angiotensin system and atheromatous renal artery stenosis. Hypertension. 1999;34:1097-1100.

4. Dessi-Fulgheri $P$, Catalini $R$, Sarzani $R$, Sturbini $S$, Siragusa $N$, Guazzaroti F, Offidani M, Tamburrine P, Zingaretti O, Rappelli A. Angiotensin converting enzyme gene polymorphism and carotid atherosclerosis in a low-risk population. J Hypertens. 1995;13:15931596.

5. Girerd X, Hanon O, Mourad JJ, Boutouyrie P, Laurent S, Jeunemaitre X. Lack of association between renin-angiotensin system, gene polymorphisms, and wall thickness of the radial and carotid arteries. Hypertension. 1998;32:579-583.

6. Jeng J-R. Carotid thickening, cardiac hypertrophy, and angiotensin converting enzyme gene polymorphism in patients with hypertension. Am J Hypertens. 2000;13:111-119.

7. Kuznetsova T, Staessen JA, Wang J-G, Gasowski J, Nikitin Y, Ryabikov A, Fagard R. Antihypertensive treatment modulates the association between the D/l ACE gene polymorhism and left ventricular hypertrophy: a meta analysis. J Hum Hypertens. 2000;14:447-454.

8. Nakahara K-I, Matsushita S, Matsuoka H, Inamatsu T, Nishinaga M, Yonawa $\mathrm{M}$, Aono $\mathrm{T}$, Arai $\mathrm{T}$, Ezaki $\mathrm{Y}$, Orimo $\mathrm{H}$. Insertion/deletion polymorphism in the angiotensin-converting enzyme gene affects heart weight. Circulation. 2000;101:148-151.

9. Clark CJ, Davies E, Anderson NH, Farmer R, Friel EC, Fraser R, Connell MC. $\alpha$-Adducin and angiotensin I-converting enzyme polymorphisms in essential hypertension. Hypertension. 2000;36:990994.

10. Giner V, Poch E, Bragulat E, Oriola J, Gonzalez D, Coca A, Sierra de la A. Renin-angiotensin system genetic polymorphisms and salt sensitivity in essential hypertension. Hypertension. 2000;35:512-517.

11. Staessen JA, Wang J-G, Ginocchio G, Petrov V, Saavedra AP, Soubrier $F$, Vlietinck $R$, Fagard $R$. The deletion/insertion polymorphism of the angiotensin converting enzyme and cardiovascular-renal risk. $J$ Hypertens. 1997;15:1579-1592.

12. Benetos A, Topouchian J, Ricard S, Gautier S, Bonnardeaux A, Asmar R, Poirier O, Soubrier F, Safar ME, Cambien F. Influence of angiotensin 
II type 1 receptor polymorphism on aortic stiffness in never-treated hypertensive patients. Hypertension. 1995;26:44-47.

13. Benetos A, Gautier S, Ricard S, Topouchian J, Asmar R, Poirier O, Larosa E, Guize L, Safar ME, Soubrier F, Cambien F. Influence of angiotensin-converting enzyme and angiotensin II type 1 receptor gene polymorphisms on aortic stiffness in normotensive and hypertensive patients. Circulation. 1996;94:698-703.

14. Pojoga L, Gautier S, Blanc H, Guyene T-T, Poirier O, Cambien F, Benetos A. Genetic determination of plasma aldosterone levels in essential hypertension. Am J Hypertens. 1998;11:856-860.

15. O'Rourke MF. Mechanical principles in arterial disease. Hypertension. 1995;26:2-9.

16. Lajemi M, Labat C, Gautier S, Lacolley P, Safar M, Asmar R, Cambien $\mathrm{F}$, Benetos $A$. Angiotensin II type 1 receptor ${ }^{-153} \mathrm{~A} / \mathrm{G}$ and ${ }^{1166} \mathrm{~A} / \mathrm{C}$ gene polymorphisms and increase in aortic stiffness with age in hypertensive subjects. J Hypertens. 2001;19:407-413.

17. Taniwaki $H$, Kawagishi $T$, Emoto M, Shoji T, Hosoi M, Kogawa K, Nishizawa $\mathrm{Y}$, Morii $\mathrm{H}$. Association of ACE gene polymorphism with arterial stiffness in patients with type 2 diabetes. Diabetes Care. 1999;22:1858-1864.

18. Staessen JA, Roels HA, Emalianov D, Kuznetsova T, Thijs L, Vangronsveld J, Fagard R, for the Public Health and Environmental Exposure to Cadmium (PheeCad) Study Group. Environmental exposure to cadmium, forearm bone-density, and risk of fractures: prospective population study. Lancet. 1999;353:1140-1144.

19. Hoeks APG, Brands PJ, Smeets FAM, Reneman RS. Assessment of the distensibility of superficial arteries. Ultrasound Med Biol. 1990;16:121128.

20. Kelly R, Fitchett D. Noninvasive determination of aortic input impedance and external left ventricular power output: a validation and repeatability study of a new technique. J Am Coll Cardiol. 1992;20:952-963.

21. Armentano R, Megnien JL, Simon A, Bellenfant F, Barra J, Levenson J. Effects of hypertension on viscoelasticity of carotid and femoral arteries in humans. Hypertension. 1995;26:48-54.

22. Bortel Van LM, Balkestein EJ, Heijden van der-Spek JJ, Vanmolkot FH, Staessen JA, Kragten JA, Vredeveld JW, Safar ME, Struijker Boudier HA, Hoeks AP. Non-invasive assessment of local arterial pulse pressure: comparison of applanation tonometry and echo-tracking. $J$ Hypertens. 2001;19:1037-1044.

23. Hoeks APG, Reneman RS. Biophysical principles of vascular diagnosis. J Clin Ultrasound. 1995;23:71-79.

24. Lindpaintner K, Pfeffer MA, Kreutz R, Stampfer MJ, Grodstein F, LaMotte F. A prospective evaluation of an angiotensin-convertingenzyme gene polymorphism and the risk of ischemic heart disease. $N$ Engl J Med. 1995;332:706-711. 
25. Livak KJ, Flood SJ, Marmaro J, Giusti W, Deetz K. Oligonucleotides with fluorescent dyes at opposite ends provide a quenched probe system useful for detecting PCR product and nucleic acid hybridization. PCR Methods Appl. 1995;4:357-362.

26. Cusi D, Barlassina C, Azzani T, Casari G, Citterio L, Devoto M, Glorioso N, Lanzani C, Manunta P, Righetti M, Rivera R, Stella P, Troffa C, Zagato L, Bianchi $G$. $\alpha$-Adducin polymorphism in primary hypertension: Linkage and association study: relationship with salt sensitivity. Lancet. 1997;350:350:369.

27. Brand E, Chatelain N, Mulatero P, Fery I, Curnow K, Jeunemaitre X, Corvol P, Pascoe L, Soubrier F. Structural analysis and evaluation of the aldosterone synthase gene in hypertension. Hypertension. 1998;32:198204.

28. Hosmer DW Jr, Lemeshow S. Interpretation of the fitted model. In: Shewhart WA, Wilks SS, eds. Applied Logistic Regression. second ed. New York: John Wiley \& Sons, Inc.; 2000:56-62.

29. Bland JM, Altman DG. Multiple significance tests: the Bonferroni method. BMJ. 1995;310:170.

30. Zeger SL, Liang KY, Albert PS. Models for longitudinal data: a generalized estimating equation approach. Biometrics. 1988;44:10491060.

31. SAS Institute Inc. SAS Online Doc : SAS/STAT. In: The GENMODE Procedure. Version 7.1 ed; 2000:1311-1411.

32. Laurent S, Lacolley P, Girerd X, Boutouyrie P, Bezie Y, Safar ME. Arterial stiffening: opposing effects of age- and hypertension-associated structural changes. Can J Physiol Pharmacol. 1996;74:842-849.

33. Staessen JA, Wang J-G, Brand E, Barlassina C, Birkenhäger $\mathrm{WH}$, Herrmann S-M, Fagard R, Tizzoni L, Bianchi G. Effects of three candidate genes on prevalence and incidence of hypertension in a Caucasian population. J Hypertens. 2001;19:1349-1358.

34. Williams SM, Addy JH, Phillips JA 3rd, Dai M, Kpodonu J, Afful J, Jackson $\mathrm{H}$, Joseph K, Eason F, Murray MM, Epperson P, Aduonum A, Wong L-J, Jose PA, Felder RA. Combinations of variations in multiple genes are associated with hypertension. Hypertension. 2000;36:2-6.

35. Barlassina C, Schork NJ, Manunta P, Citterio L, Sciarrone MT, Lanella G, Bianchi G, Cusi D. Synergistic effect of $\alpha$-adducin and ACE genes causes blood pressure changes with body sodium and volume expansion. Kidney Int. 2000;57:1083-1090.

36. Rigat B, Hubert C, Alhenc-Gelas F, Cambien F, Corvol P, Soubrier F. An insertion/deletion polymorphism in the angiotensin l-converting enzyme gene accounting for half the variance of serum enzyme levels. $J$ Clin Invest. 1990;86:1343-1346.

37. Müller DN, Bohlender J, Hilgers KF, Dragun D, Costerousse O, Menard $J$, Luft FC. Vascular angiotensin-converting enzyme expression regulates local angiotensin II. Hypertension. 1997;29:98-104. 
Chapter 5

Modulation of the ACE Genotype Effect on Systemic Vascular Resistance Index by the $\alpha$-Adducin Polymorphism in the General

Population

E.J. Balkestein

J.A. Staessen

J-G. Wang

E. Den Hond

L.M. Van Bortel

C. Barlassina

G. Bianchi

E. Brand

S-M Herrmann

H.A. Struijker Boudier

Submitted 


\section{Abstract}

We recently reported associations between angiotensin-converting enzyme $(A C E)$ insertion/deletion (I/D), $\alpha$-adducin Gly460Trp and the aldosterone synthase $C-344 T$ gene polymorphisms and the incidence of hypertension, femoral intima-media thickness and renal function in a population-based study of European ancestry. In the present study we investigated whether these polymorphisms have an influence on systemic vascular resistance index.

A sample of 303 subjects enrolled in a population study underwent echocardiography to determine cardiac index and systemic vascular resistance index. All subjects were genotyped for the ACE I/D, $\alpha$-adducin Gly460Trp, and aldosterone synthase C-344T polymorphisms. Statistical analysis allowed for confounders, non-independence of the phenotype between related individuals and multiple-gene effects. The sample included 149 men (49.2\%) and 154 women (50.8\%) whose age averaged 37 years (1276 years). Mean systemic vascular resistance index was $31.0 \pm 7.5$ $\mathrm{mmHg} / \mathrm{L} / \mathrm{min} / \mathrm{m}^{2}$, cardiac index averaged $2.95 \pm 0.70 \mathrm{~L} / \mathrm{min} / \mathrm{m}^{2}$. Systemic vascular resistance index increased with the number of $A C E D$ alleles with a difference between ACE $I$ and ACE $D$ homozygotes, expressed as a percentage of the population mean, of $8.8 \%(95 \% \mathrm{Cl}: 1.7$ to $15.9 \%, \mathrm{p}<0.01)$. Cardiac index decreased with the number of $A C E D$ alleles with a difference between ACE I/ and ACE DD homozygotes of $7.0 \%(95 \% \mathrm{Cl}: 0.3$ to $13.7 \%$, $\mathrm{p}<0.04)$. For $\alpha$-adducin and aldosterone synthase gene polymorphisms, no single-gene effect was observed. In further multiple-gene analyses, the observed ACE $D$ allele effect was restricted to subjects with the $\alpha$-adducin GlyGly genotype, in whom systemic vascular resistance index was $17.7 \%$ (95\%Cl: 9.4 to $26.0 \%, \mathrm{p}<0.001$ ) higher in $A C E D D$ subjects than in $A C E$ I homozygotes, whereas the opposite was observed for cardiac index with a difference of $11.7 \%(95 \% \mathrm{Cl}: 4.3$ to $19.1 \%, \mathrm{p}<0.01)$. No interaction was observed between the ACE I/D and aldosterone synthase C-344T genotypes.

The present study demonstrates a relationship between systemic vascular resistance index and the $A C E I / D$ polymorphism, which is modulated by the $\alpha$-adducin Gly460Trp polymorphism. These findings show the importance of studying multiple-gene effects in the pathogenesis of hypertension, rather than single-gene effects. 
We recently reported that the incidence of hypertension is influenced by the angiotensin-coverting enzyme (ACE, I/D), $\alpha$-adducin (Gly460Trp) and aldosterone synthase gene (C-344T) polymorphism. ${ }^{1}$ In a subset of this population we also observed that large artery structural (unpublished data) and functional ${ }^{2}$ properties are influenced by these polymorphisms.

We selected the three aforementioned genes for a study based on the 'a priori' hypothesis that all three polymorphisms might raise blood pressure via stimulation of sodium reabsorption in the kidney and chronic expansion of the circulating volume. The association between large artery stiffness and the

ACE $I / D, \alpha$-adducin Gly460Trp and aldosterone synthase $C$-344T gene polymorphisms indicated that there could be local effects of these combined genetic variants on the vascular wall, $^{3}$ superimposed on an adaptive mechanism of the vessel wall to the higher circulating volume or blood pressure. ${ }^{4}$ Our initial studies focused on functional and structural properties of the large arteries. However, one of the pronounced hemodynamic abnormalities in subjects presenting with essential hypertension is an increased vascular resistance, which is related to smaller arteries. The purpose of the present study was to investigate whether the multiple-gene effects which have been previously observed in relation to the structure and function of the large arteries, may also be of importance for peripheral vascular resistance. For this purpose, we determined systemic vascular resistance index in a sample of 303 subjects of our previously described study population. ${ }^{2}$

Methods

\section{Study population}

The Flemish Study on Environment, Genes and Health Outcomes (FLEMENGHO) started in 1985. The Ethics Committee of the University of Leuven approved its protocol. From August 1985 until November 1990, a random sample of the households living in a geographically defined area of Northern Belgium was recruited. ${ }^{5}$ To further investigate the role of genetic factors, from June 1996 until January 1999, the study population was enlarged with nuclear families including children who were at least 10 years old, using the former participants as index persons. The participants or their parents gave informed consent. The participation rate among all subjects contacted was $64.3 \%$. For the present study ultrasound studies were performed in 380 subjects. After exclusion for missing outcome- or confounding variables $(n=63)$ and the presence of aortic valve disease $(n=12), 303$ subjects were included in the analysis. 
Measurements

Before examination of participants in our field centre, they refrained from smoking, heavy exercise, and drinking alcohol or caffeine containing beverages for at least 3 hours. Blood pressure was measured 5 times consecutively after 5 minutes rest and in a sitting position. Hypertension was diagnosed if the average of the 5 blood pressure readings was at least $140 \mathrm{mmHg}$ systolic or $90 \mathrm{mmHg}$ diastolic, or when subjects were on antihypertensive medication. A venous blood sample was obtained for measurement of serum lipids and genotyping. Information concerning health status, medical history, family history, smoking and drinking habits and the use of medication was obtained by a standardized interview by a trained nurse. Body weight and height were assessed and body surface area (BSA) was calculated by the following formula: BSA $\left(\mathrm{m}^{2}\right)=$ body weight $(\mathrm{kg})^{0.425} \times$ body height $(\mathrm{cm})^{0.725} \times 71.84{ }^{6}$

\section{Hemodynamic measurements}

Subjects were examined after 15 minutes of supine rest. Ascending aortic flow was measured with continuous wave Doppler from the sternal notch and heart rate (HR) was recorded simultaneously. ${ }^{7}$ In the left lateral position, from a short axis view of the aorta, M-mode recordings were obtained with visualisation of at least 2 aortic cups. Off-line, aortic diameter (Ao) was measured according to standard procedures. ${ }^{8}$ Systolic (SBP), diastolic (DBP) and mean arterial pressure (MAP) were measured at a three-minute interval with a Dinamap 845 oscillometric device (Critikon, Tampa, Florida, USA). The mean of 15 measurements was taken as the subject's value. From the velocity time integral (VTI), which was automatically calculated from the Doppler flow signals of 5 consecutive heart cycles, stroke volume (SV) was calculated as SV $(\mathrm{ml})=\mathrm{VTI} \bullet$ Ao. Stroke index was calculated as SV $/$ BSA $\left(\mathrm{ml} / \mathrm{m}^{2}\right)$. Cardiac output was calculated as $\mathrm{SV} \cdot \mathrm{HR}$. Cardiac index $(\mathrm{Cl})$ was calculated by dividing $\mathrm{CO}$ by BSA. Systemic vascular resistance index was calculated as MAP/CI. All measurements were performed by a single investigator. Intra-session coefficients of variance for velocity time integrals and aortic diameter measurements were $2.5 \pm 1.9 \%$ and $2.6 \pm 1.5 \%$, respectively.

\section{Genotyping}

The ACE I/D genotypes were determined as previously described. ${ }^{9}$ All samples genotyped as $D D$ underwent a second polymerase chain reaction using insertion-specific primers.

The sense primer was 5' TGGGACCACAGCGCCCGCCACTAC 3', the antisense primer was 5' TCGCCAGCCCTCCCATGCCCATAA 3'.

Allelic discrimination of the $\alpha$-adducin Gly460Trp was carried out using a 5 ' nuclease assay ${ }^{10}$ on an ABI Prism 7700 apparatus (Perkin Elmer, Norwalk, 
CT) as recently described by Cusi et al. ${ }^{11}$ The forward and reverse primers and the 460Gly and 460Trp probes employed in the TAQMan assay were 5'CGTCCACACCTTAGTCTTCGACTT-3', 5'-GGAGAAGACAAGATGGCTGAACTC-3', 5'-FAMTTCCATTCTGCCCTTCCTCGGA-TAMRA-3' and 5'-TETTTCCATTCTGCCATTCCTCGGAA-TAMRA-3', respectively. Genotyping for aldosterone synthase $C-344 T$ was performed as recently described by Brand et al. ${ }^{12}$

\section{Statistical analysis}

For statistical analysis we used SAS version 8.1 (SAS Institute, Cary, NC). Significant covariates for SVRI and $\mathrm{Cl}$ were traced by stepwise linear regression. In multiple linear regression, the genotypes were first represented by dummy variables using the deviation from mean coding approach, ${ }^{13}$ which does not imply any genetic hypothesis. In single-gene analyses in which we tested independent hypotheses, we additionally adjusted $\alpha$-levels and confidence intervals for multiple testing using Bonferroni's methods. ${ }^{14}$ Because family members are more likely to share identical alleles than randomly selected subjects, we performed all analyses using generalized estimating equations to account for the non-indepence of the vascular phenotypes within families. ${ }^{15}$ In the PROC GENMOD procedure we defined the intrafamilial correlation matrices with adjustments applied for covariables and confounders.

\section{Results}

Characteristics of the study population

The study population included 149 (49.2\%) men and 154 (50.8\%) women (Table 1). Smoking habits did not differ between men and women with a total of $87(28.7 \%)$ current smokers. 110 men $(74 \%)$ drank alcohol compared with 61 women (40\%). In total, 62 persons were hypertensive of which $24(38.7 \%)$ were on antihypertensive treatment. 14 women (4.6\%) used oral contraceptives, whereas none of the older women used hormonal replacement therapy.

The genotype frequencies for $A C E / / D$ did not deviate from Hardy-Weinberg equilibrium with frequencies of $31.7 \%, 47.2 \%$ and $21.1 \%$ for $I I, I D$ and $D D$ genotypes, respectively $(P=0.43)$. The genotypes of $\alpha$-adducin Gly460Trp and aldosterone synthase $C-344 T$ were also distributed as expected by the HardyWeinberg equilibrium with $P$ values of 0.22 and 0.28 respectively. The genotype frequencies were $58.4 \%, 34.4 \%$ and $7.3 \%$ for $\alpha$-adducin GlyGly, GlyTrp and TrpTrp, and $19.8 \%, 52.8 \%$ and $27.4 \%$ for aldosterone synthase $C C, C T$ and $T T$, respectively. 
Single-Gene Effects

Stepwise regression analysis identified gender and antihypertensive drug treatment as significant covariables of systemic vascular resistance index, and age and antihypertensive treatment as significant covariables of cardiac index and stroke index. With cumulative adjustment for these covariables as well as for the non-independence of the vascular phenotypes within families, no single-gene effect was found to be significant for the aldosterone synthase $C$-344T or $\alpha$-adducin Gly460Trp polymorphisms in relation to systemic vascular resistance index or cardiac index (Table 2). ACE $D$ homozygotes tended to deviate from the population mean for systemic vascular resistance index and cardiac index (Table 2). Systemic vascular resistance index increased whereas cardiac index decreased with the number of $A C E D$ alleles. Indeed, expressed as a percentage of the population mean, the difference between $A C E$ I and $D$ homozygotes averaged $8.8 \%(95 \% \mathrm{Cl}: 1.7-15.9 \%$, $P<0.01)$ for systemic vascular resistance index and $7.0 \%(95 \% \mathrm{Cl}: 0.3-$ $13.7 \%, P<0.04)$ for cardiac index. The difference in mean arterial pressure between $A C E$ I and $D$ homozygotes was not statistically significant $(P=0.57)$, as was the difference in stroke index $(P=0.60)$ 
Multiple-gene effects

In multiple-gene analyses, with similar adjustments as applied in the singlegene approach, we found significant differences in systemic vascular resistance index and cardiac index according to the ACE genotype, but this was restricted to $\alpha$-adducin Gly460 homozygotes. ACE DD subjects, homozygous for $\alpha$-adducin Gly 460 , differed from the population mean with a higher systemic vascular resistance index: $+9.5 \%(95 \% \mathrm{Cl}: 2.3$ to $16.7 \%$; $P=0.008$ ) and II subjects homozygous for $\alpha$-adducin Gly460 had a lower systemic vascular resistance index: $-8.2 \%(95 \% \mathrm{Cl}:-12.3$ to $-4.1 \% ; P<0.0001)$. Cardiac index was lower compared to the population mean in ACE DD subjects and higher for ACE II subjects homozygous for $\alpha$-adducin Gly460 with deviations of $-6.5 \%(95 \% \mathrm{Cl}:-0.6$ to $-12.4 \% ; P=0.03)$ and $5.1 \%(95 \% \mathrm{Cl}$ : 0.8 to $9.4 \% ; P=0.02$ ) respectively (figure). Stroke index decreased with the number of ACE $D$ alleles in $\alpha$-adducin Gly460 homozygotes. ACE DD subjects homozygous for $\alpha$-adducin Gly460 deviated significantly from the population mean with $-6.0 \%(95 \% \mathrm{Cl}:-0.5$ to $-11.5 \% ; P=0.03)$. Mean arterial pressure did not differ according to the ACE genotype irrespective of the $\alpha$-adducin Gly460Trp genotype.

The hemodynamic measurements were not significantly associated with any combination of aldosterone synthase and $\alpha$-adducin genotypes. 


\section{Discussion}

The main finding of our population-based study was that in subjects homozygous for the common $\alpha$-adducin Gly460 allele, the ACE $D$ allele was associated with increased systemic vascular resistance index. This association does not result in higher blood pressure, because in $\alpha$-adducin Gly460 homozygotes the $A C E D$ allele was also associated with lower stroke volume but unchanged heart rate, and hence lower stroke index.

Several studies investigated the $A C E I / D$ polymorphism in relation to local vascular resistance and/or reactivity in vivo ${ }^{16-20}$ or in vitro. ${ }^{21}$ In Japanese type 1 diabetic patients, renal vascular resistance increased in the presence of the ACE $D$ allele. ${ }^{17}$ However, in Canadian patients with type 1 diabetes mellitus, ${ }^{20}$ and in healthy Japanese subjects, renal vascular resistance was not related to the $A C E I / D$ polymorphism under basal conditions. ${ }^{16}$ In addition, renal vascular resistance did not decrease in Japanese ACE DD subjects in response to ACE inhibitor therapy. Similarly, hypertensive patients homozygous for the ACE $D$ allele showed a blunted vasodilatory response to acetylcholine of the fore-arm arteries. ${ }^{18}$ However, these findings were not confirmed in normotensive subjects. ${ }^{19}$ Furthermore, an in vitro study by Steeds et $\mathrm{al}^{21}$ showed an association of the $A C E I / D$ polymorphism with contractility of mesenteric resistance arteries.

Our findings on the aldosterone synthase gene polymorphism are in line with the findings of Kupari et $a^{22}$ where, in a sample of 84 subjects drawn from the general population, no association was reported between the aldosterone synthase $C-344 T$ polymorphism and systemic vascular resistance.

The abovementioned studies have different outcomes, which might be explained by the diversity of both the populations and the phenotypes studied. The systemic pressor response in diabetic subjects to hyperglycemia, ${ }^{20}$ could lead to vascular wall adaptation which might, with time, overrule the possible effect of the $A C E I / D$ polymorphism observed in non-diabetic subjects.

However, our finding on the association of the ACE I/D polymorphism with systemic vascular resistance is at odd with the findings of Mizuiri et $a l,{ }^{16}$ which could be due to the small sample size $(n=24)$ in the latter study. The interaction between the $A C E I / D$ polymorphism and ethnicity as observed in black and white Americans by Gainer et $\mathrm{al}^{19}$ could also explain differences in outcome according to the race investigated.

Furthermore, local expression and activity of ACE within specific arterial beds could be rate limiting, thereby altering the paracrine activity of angiotensin II. Hence, the renal vascular resistance arteries might not exhibit the same genotype dependency such as total systemic vascular resistance. The same holds for the negative finding of an association of $A C E I / D$ with isolated human resistance arteries by Steeds et al. ${ }^{21}$

Hypertensives carrying the mutated $\alpha$-adducin 460Trp allele exhibit enhanced proximal tubular reabsorption of sodium ${ }^{23}$ and experience larger blood pressure changes in response to sodium loading or diuretic treatment. ${ }^{24}$ One could hypothesize that in the absence of the mutated $\alpha$-adducin $460 T r p$ allele 
the circulating volume is less, as marked by a lower cardiac index. Normotensive ACE DD subjects have been shown to exhibit an enhanced pressor response to angiotensin I. $^{25}$ These subjects might therefore exhibit a higher systemic vascular resistance index.

In the hypertension literature, for a long time, a distinction has been made between volume-dependent and volume-independent hypertension. ${ }^{26}$ Our present findings suggest that in $\alpha$-adducin Gly460 homozygotes, the ACE $D$ allele may be associated with a volume-independent type of increased blood pressure. Indeed, the high systemic vascular resistance combined with low cardiac index may reflect enhanced vasoconstriction. In constrast, in carriers of the $\alpha$-adducin 460Trp allele there was no significant association between the hemodynamic measurements and the ACE $D$ allele. In these subjects the less frequent $\alpha$-adducin 460Trp allele increased tubular sodium reabsorption and chronic volume expansion, which may attenuate or mask the effect of the $A C E D$ allele which is probably mediated via higher systemic ACE activity and angiotensin II generation. In keeping with this hypothesis, Barlassina and coworkers $^{27}$ found that plasma renin activity was suppressed in subjects carrying both the $\alpha$-adducin 460Trp and ACE $D$ alleles.

Our data cannot be interpreted without caution. Dual pathways exist for the generation of angotensin $\|^{28,29}$ and it has been debated whether the ACE I/D polymorphism influences circulating angiotensin II levels. ${ }^{30,31}$

Furthermore, the role of $\alpha$-adducin in the prevalence of hypertension has been debated. ${ }^{32-38}$. Failure to account for the genetic interactions between the $\alpha$-adducin and ACE gene polymorphisms may help to explain the controversial results on associations of $\alpha$-adducin Gly460Trp polymorphism with essential hypertension. ${ }^{24,39}$

However, a recent study failed to demonstrate an interaction between $\alpha$-adducin Gly460Trp and ACE I/D on hypertension, which also could be due to the relatively small size $(n=128)$ of this case control study. ${ }^{40}$ Our previous findings in the general population on the prevalence and incidence of hypertension, ${ }^{1}$ femoral intima media thickness (unpublished data) and large artery properties ${ }^{2}$ strengthen the importance of the $\alpha$-adducin Gly460Trp polymorphism in the pathogenesis of vascular disease, not as a single gene but in concert with the ACE I/D polymorphism.

In conclusion, with our present findings we propose possible genetic mechanisms in the pathogenesis of essential hypertension. The proposed pathogenesis warrants further research on cellular mechanisms underlying these phenomena. Moreover, future research on vascular reactivity in the general population based on both the ACE I/D and $\alpha$-adducin Gly460Trp gene polymorphisms might elucidate our current as well as previous findings.

Acknowledgements

The FLEMENGHO Study was supported by research grants G.0174.97 and G.0291.98 from the Fonds voor Wetenschappelijk Onderzoek Vlaanderen (Brussels, Belgium) and by a special research grant from the Katholieke Universiteit Leuven (Onderzoekstoelage OT99/28). Nuclear families were 
recruited in the framework of the European Project on Genes in Hypertension, which is supported by the European Union (contract IC15-CT98-0329-EPOGH and QLG1-CT-2000-01137-EURNETGEN). The Flemish population study would not have been possible without the collaboration of the family physicians of the participants. The municipality Hechtel-Eksel (Belgium) provided logistic support. The authors acknowledge the expert assistance of Leszek Bieniaszewski MD, Rina Bollen, Lut De Pauw RN, Hilde Celis MD, Primoz Dolenc MD, Paul Drent, Dmitri Emelianov MD, Jerzy Gasowski MD, Heng Fan, Lieve Gijsbers, Alida Hermans, Tatyana Kuznetsova MD, Tim Nawrot BSC, Lutgarde Thijs BSC, Yvette Toremans, Sylvia Van Hulle RN and Renilde Wolfs (Study Coordinating Centre, Leuven, Belgium). Genetic studies in Berlin, Germany, were supported by grants from the Deutsche Forschungsgemeinschaft to Eva Brand (BR 1589/1-1) and Stefan-Martin Herrmann (HE 2852/1-1) and by a grant from the Société Française d'Hypertension Artérielle to Eva Brand. Brigitte Egbers (Berlin) determined the aldosterone-synthase genotypes. Stephan-Martin Herrmann is participant in the grants of the Deutsche Forschungsgemeinschaft: "Graduierten-Kolleg 426/2-00, Molekularbiologische Grundlagen der Therapie" and "GraduiertenKolleg 754, Myokardiale Genexpression und Funktion, Myokardhypertrophie". 
1. Staessen JA, Wang J-G, Brand E, Barlassina C, Birkenhager WH, Herrmann S-M, Fagard R, Tizzoni L, Bianchi G. Effects of three candidate genes on prevalence and incidence of hypertension in a Caucasian population. J Hypertens. 2001;19:1349-1358.

2. Balkestein EJ, Staessen JA, Wang JG, Heijden van der- Spek JJ, Bortel Van LM, Barlassina C, Bianchi G, Brand E, Herrmann S-M, Struijker Boudier HA. Carotid and femoral artery stiffness in relation to three candidate genes in a white population. Hypertension. 2001;38:11901197.

3. Blaustein MP. Sodium transport and hypertension; where are we going? Hypertension. 1984;6:445-453.

4. Laurent S, Lacolley P, Girerd X, Boutouyrie P, Bezie Y, Safar ME. Arterial stiffening: opposing effects of age- and hypertension-associated structural changes. Can J Physiol Pharmacol. 1996;74:842-849.

5. Staessen JA, Roels HA, Emalianov D, Kuznetsova T, Thijs L, Vangronsveld J, Fagard R, for the Public Health and Environmental Exposure to Cadmium (PheeCad) Study Group. Environmental exposure to cadmium, forearm bone-density, and risk of fractures: prospective population study. Lancet. 1999;353:1140-1144.

6. Du Bois D, Du Bois EF. A formula to estimate the approximate surface area if height and weight be known. Arch Intern Med. 1916;17:863-871.

7. Huntsman LL, Stewart DK, Barnes SR, Franklin SB, Colocousis JS, Hessel EA. Noninvasive Doppler determination of cardiac output in man; clinical validation. Circulation. 1983;67:593-602.

8. Devereux RB, Liebson PR, Horan MJ. Recommendations concerning use of echocardiography in hypertension and general population research. Hypertension. 1987;9:II-97-II-104.

9. Lindpaintner K, Pfeffer MA, Kreutz R, Stampfer MJ, Grodstein F, LaMotte F. A prospective evaluation of an angiotensin-convertingenzyme gene polymorphism and the risk of ischemic heart disease. $N$ Engl J Med. 1995;332:706-711.

10. Livak KJ, Flood SJ, Marmaro J, Giusti W, Deetz K. Oligonucleotides with fluorescent dyes at opposite ends provide a quenched probe system useful for detecting PCR product and nucleic acid hybridization. PCR Methods Appl. 1995;4:357-362.

11. Cusi D, Barlassina C, Azzani T, Casari G, Citterio L, Devoto M, Glorioso N, Lanzani C, Manunta P, Righetti M, Rivera R, Stella P, Troffa C, Zagato L, Bianchi $\mathrm{G}$. $\alpha$-Adducin polymorphism in primary hypertension: Linkage and association study: relationship with salt sensitivity. Lancet. 1997;350:350:369.

12. Brand E, Chatelain N, Mulatero P, Fery I, Curnow K, Jeunemaitre X, Corvol P, Pascoe L, Soubrier F. Structural analysis and evaluation of the aldosterone synthase gene in hypertension. Hypertension. 1998;32:198204. 
13. Hosmer DW Jr, Lemeshow S. Interpretation of the fitted model. In: Shewhart WA, Wilks SS, eds. Applied Logistic Regression. second ed. New York: John Wiley \& Sons, Inc.; 2000:pp. 56-62.

14. Bland JM, Altman DG. Multiple significance tests: the Bonferroni method. BMJ. 1995;310:170.

15. Zeger SL, Liang KY, Albert PS. Models for longitudinal data: a generalized estimating equation approach. Biometrics. 1988;44:10491060.

16. Mizuiri S, Hemmi H, Inoue A, Takano M, Kadomatsu S, Tanimoto H, Tanegashima M, Hayashi I, Fushimi T, Hasegawa A. Renal hemodynamic changes induced by captopril an angiotensin-converting enzyme gene polymorphism. Nephron. 1997;75:310-314.

17. Fukumoto S, Ishimura E, Hosoi M, Kawagishi T, Kawamura T, Isshiki G, Nishizawa $Y$, Morii $H$. Angiotensin converting enzyme gene polymorphism and renal artery resistance in patients with insulin dependent diabetes mellitus. Life Sci. 1996;59:629-637.

18. Perticone F, Ceravolo R, Maio R, Ventura G, Zingone A, Perrotti N, Mattioli PL. Angiotensin-converting enzyme gene polymorphism is associated with endothelium-dependent vasodilation in never treated hypertensive patients. Hypertension. 1998;31:900-905.

19. Gainer JV, Stein CM, Neal T, Vaughan DE, Brown NJ. Interactive effects of ethnicity and ACE insertion/deletion polymorphism on vascular reactivity. Hypertension. 2001;37:46-51.

20. Miller JA, Scholey JW, Thai K, Pei YPC. Angiotensin converting enzyme gene polymorphism and renal hemodynamic function in early diabetes. Kidney Int. 1997;51:119-124.

21. Steeds RP, O'Toole LO, Channer KS, Morice AH. Human vascular reactivity and polymorphisms of the angiotensin-converting enzyme and the angiotensin Type 1 receptor. J Vasc Res. 1999;36:445-455.

22. Kupari M, Hautanen A, Lankinen L, Koskinen P, Virolainen J, Nikkila H, White PC. Associations between human aldosterone synthase (CYP11B2) gene polymorphism and left ventricular size, mass and function. Circulation. 1998;97:569-575.

23. Bianchi G, Cusi D. $\alpha$-Adducin: is the glass half full or half empty? Am J Hypertens. 2000;13:739-743.

24. Cusi D, Barlassina C, Azzani T, Casari G, Devoto M, Glorioso N, Lanzani C, Manunta P, Righetti M, Rivera R, Stella P, Troffa C, Zagato L, Bianchi G. Polymorphism of alpha-adducin and salt sensitivity in patients with essential hypertension. Lancet. 1997;349:1353-1357.

25. Ueda S, Elliott HL, Morton JJ, Connell JMC. Enhanced pressor response to angiotensin $\mathrm{I}$ in normotensive men with the deletion genotype (DD) for angiotensin-converting enzyme. Hypertension. 1995;25:1266-1269.

26. Williams GH, Fisher NDL, Hunt SC, Jeunemaitre X, Hopkins PN, Hollenberg NK. Effects of gender and genotype on the phenotypic 
expression of nonmodulating essential hypertension. Kidney Int. 2000;57:1404-1407.

27. Barlassina C, Schork NJ, Manunta P, Citterio L, Sciarrone MT, Lanella G, Bianchi G, Cusi D. Synergistic effect of $\alpha$-adducin and ACE genes causes blood pressure changes with body sodium and volume expansion. Kidney Int. 2000;57:1083-1090.

28. Padmanabhan N, Jardine AG, McGrath JC, Connell JMC. Angiotensinconverting enzyme-independent contraction to angiotensin I in human resistance arteries. Hypertension. 1999;99:2914-2920.

29. Hollenberg NK. Implications of species difference for clinical investigation. Studies on the renin-angiotensin system. Hypertension. 2000;35:150-154.

30. Lachurie M-L, Azizi M, Guyene T-T, Alhenc-Gelas F, Menard J. Angiotensin -convering enzyme gene polymorphism has no influence on the circulating renin-angiotensin-aldosterone system or blood pressure in normotensive subjects. Circulation. 1995;91:2933-2942.

31. Müller DN, Bohlender J, Hilgers KF, Dragun D, Costerousse O, Menard $J$, Luft FC. Vascular angiotensin-converting enzyme expression regulates local angiotensin II. Hypertension. 1997;29:98-104.

32. Larson N, Hutchinson R, Boerwinkle E. Lack of assocation of 3 functional gene variants with hypertension in african americans. Hypertension. 2000;35:1297-1300.

33. Melander O, Bengtsson K, Orho-Melander M, Lindblad U, Forsblom C, Rastam L, Groop L, Hulthen UL. Role of the Gly460Trp polymorphism of the $\alpha$-adducin gene in primary hypertension in Scandinavians. J Hum Hypertens. 2000;14:43-46.

34. Niu T, Xu X, Cordell HJ, Rogus J, Zhou Y, Fang Z, Lindpainter K. Linkage analysis of candidate genes and gene-gene interactions in Chinese hypertensive sib pairs. Hypertension. 1999;33:1332-1337.

35. Province MA, Arnett DK, Hunt SC, Leiendecker-Foster $\mathrm{C}$, Eckfeldt $\mathrm{H}$, Oberman A, Ellison RC, Heiss G, Mockrin SC, Williams RR. Association between the $\alpha$-Adducin genes and hypertension in the HyperGEN study. Am J Hypertens. 2000;13:710-718.

36. Psaty BM, Doggen C, Vos HL, Vandenbroucke JP, Rosendaal FR. Association of the $\alpha$-adducin polymorphism with blood pressure and risk of myocardial infarction. J Hum Hypertens. 2000;14:95-97.

37. Ranade K, Hsuing AC, Wu KD, Chang MS, Chen YT, Hebert J, Chen YD, Olshen R, Curb D, Dzau V, Botstein D, Cox D, Risch N. Lack of evidence for an association between $\alpha$-Adducin and blood pressure regulation in asian populations. Am J Hypertens. 2000;13:704-709.

38. Schork NJ, Chakravarti A, Thiel B, Fornage M, Jacob HJ, Cai R, Rotimi $\mathrm{CN}$, Cooper RS, Weder AB. Lack of associations between a biallelic polymorphism in the Adducin gene and blood pressure in whites and african americans. Am J Hypertens. 2000;13:693-698. 
39. Boerwinkle E. All for one and one for all: introduction to a coordinated analysis of the Gly-460-Trp $\alpha$-Adducin polymorphism. Am J Hypertens. 2000;13:734-735.

40. Clark CJ, Davies E, Anderson NH, Farmer R, Friel EC, Fraser R, Connell MC.

$\alpha$-Adducin and angiotensin I-converting enzyme polymorphisms in essential hypertension. Hypertension. 2000;36:990-994. 
Chapter 6

Carotid and femoral intima-media thickness in relation to three candidate genes in a Caucasian population

E.J. Balkestein

J-G Wang

J.A. Staessen

C. Barlassina

G. Bianchi

W.H. Birkenhäger

E. Brand

E. Den Hond

R. Fagard

S-M Herrmann

L.M. Van Bortel

H.A.J. Struijker Boudier

Provisionally accepted Journal of Hypertension 
Background In a Caucasian population, the prevalence and incidence of hypertension, renal function and large artery stiffness were significantly correlated with polymorphisms in the genes encoding the angiotensinconverting enzyme $(A C E I / D)$, aldosterone synthase $(-C 344 T)$ and the cytoskeleton protein $\alpha$-adducin (Gly460Trp).

Objective This study investigated intima-media thickening, a precursor of atherosclerosis, in relation to these genetic polymorphisms.

Methods Carotid and femoral intima-media thickness were assessed with a wall-track system in 380 subjects enrolled in a population study. Subjects were genotyped for the presence of the ACE D, aldosterone synthase $-344 T$ and $\alpha$-adducin 460Trp alleles. The statistical analysis allowed for confounders, interactions among genes, and the non-independence of the phenotypes within families.

Results The sample included 188 men (49.5\%). Mean age was 39.8 years. Intima-media thickness of the carotid and femoral arteries averaged $575 \mu \mathrm{m}$ and $719 \mu \mathrm{m}$, respectively. Intima-media thickness of the femoral - but not carotid - artery increased with the number of ACE D alleles. The effect of $A C E$ genotype on femoral intima-media thickness was confined to carriers of the 460Trp allele and the $-344 T$ allele. Expressed as a percentage of the population mean, the mean differences between II and $D D$ homozygotes averaged $13.4 \%(95 \% \mathrm{Cl} 5.6-21.2 \%)$ in all subjects, $21.2 \%(8.0-34.5 \%)$ in carriers of the $460 \mathrm{Trp}$ allele, $15.4 \%(4.1-26.8 \%)$ in carriers of the $-344 T$ allele, and $25.2 \%(10.7-39.7 \%)$ if the $460 T r p$ and $-344 T$ alleles were both present.

Conclusion This study shows that a relationship exists between the intimamedia thickness of the large muscular femoral artery and the ACE gene. This relationship is only apparent in the presence of either the $\alpha$-adducin 460Trp or the aldosterone synthase $-344 T$ allele. These findings may have clinical implications for the assessment of genetic cardiovascular risk. 


\section{Introduction}

We recently found in a Caucasian population that blood pressure, the prevalence and incidence of hypertension, ${ }^{1}$ renal function ${ }^{2}$ and stiffness of the femoral and carotid arteries, ${ }^{3}$ were significantly correlated with polymorphisms in the genes encoding the angiotensin-converting enzyme ( $A C E I / D)$, aldosterone synthase $(C-344 T)$ and the cytoskeleton protein $\alpha$-adducin (Gly460Trp). Homozygous carriers of the ACE D allele showed a higher incidence of hypertension than the other $A C E$ genotypes. The incidence of hypertension was further increased in ACE DD homozygotes who also carried the $\alpha$-adducin $460 T r p$ allele. ${ }^{1}$ In cross-sectional analyses, systolic blood pressure and the prevalence of hypertension were significantly elevated among subjects who carried both the $\alpha$-adducin 460Trp and the aldosterone synthase $-344 T$ alleles. ${ }^{1}$ Furthermore, serum creatinine and creatinine clearance were slightly but significantly higher and lower, respectively and proteinuria was significantly higher in subjects having both the $\alpha$-adducin 460Trp and ACE D alleles. ${ }^{2}$ Large artery stiffness was significantly related to the $A C E I / D$ genotype, but this relationship depended on vascular territory and genetic background. ${ }^{3}$ Carriers of the ACE $D$ allele compared with II homozygotes, have systemically increased ACE levels, which may promote the local generation of angiotensin $\mathrm{II}^{4,5}$ and hence vascular growth. ${ }^{6}$ Intimamedia thickening of the large arteries is a precursor of frank atherosclerosis and a harbinger of cardiovascular complications. ${ }^{7-9}$

The hypothesis underlying our previous studies was that interactions between the three candidate genes might raise blood pressure and influence renal function via stimulation of sodium reabsorption in the kidney and chronic expansion of the circulating fluid volume. ${ }^{1}$ These mechanisms may be sufficient to engender structural changes in the wall of large arteries. To test this hypothesis, we investigated the effects of the three aforementioned candidate genes, alone and combined, on the intima-media thickness of the elastic common carotid artery and the muscular femoral artery in a subgroup of subjects enrolled in our population study. ${ }^{1}$

\section{Methods}

Study population

The Flemish Study on Environment, Genes and Health Outcomes (FLEMENGHO) started in 1985. Its protocol was approved by the Ethics Committee of the University of Leuven. From August 1985 until November 1990, we recruited a random sample of the households living in a geographically defined area of Northern Belgium. ${ }^{10}$ To further investigate the role of genetic factors, from June 1996 until January 1999, the study population was enlarged with nuclear families including children who were at least 10 years old, using the former participants as index persons. The participants or their parents gave informed consent. The participation rate among all subjects contacted was $64.3 \% .^{1-3}$ 
For the present study, we collected measurements of carotid and femoral intima-media thickness in 392 subjects. Because of missing values of potentially important confounding variables, 12 subjects were excluded, leaving 380 persons for analysis.

Field work

Before the participants were examined at our field centre, they refrained from smoking, heavy exercise, and drinking alcohol or caffeine containing beverages for at least 3 hours. Their blood pressure was measured 5 times consecutively after they had rested for 5 minutes and were sitting. Hypertension was diagnosed if the average of the 5 blood pressure readings was at least $140 \mathrm{~mm} \mathrm{Hg}$ systolic or $90 \mathrm{~mm} \mathrm{Hg}$ diastolic, or when the subjects were on antihypertensive medication. On a separate day, validated ${ }^{11}$ oscillometric SpaceLabs 90202 or 90207 monitors (Redmond, WA) fitted with the same cuff size as for the conventional measurements, were programmed to obtain readings with an interval of 20 minutes for at least 12 hours between 8 and 22 hours. Every month the recorders were checked for accuracy against a mercury column. The mean daytime blood pressure was calculated from unedited recordings with weights according to the time interval between successive readings. ${ }^{12}$ White-coat hypertension was assumed to be present if patients who were hypertensive on conventional measurement and who were untreated, had a daytime ambulatory blood pressure lower than $135 \mathrm{~mm} \mathrm{Hg}$ systolic and $85 \mathrm{~mm} \mathrm{Hg}$ diastolic. 12,13

A venous blood sample was obtained for measurement of serum lipids, blood glucose and genotypes.

The same observer (E.J.B.) performed all vascular measurements, using a wall-tracking ultrasound system with a $7.5 \mathrm{MHz}$ probe. ${ }^{14}$ She recorded the intima-media thickness of the right common carotid artery $2 \mathrm{~cm}$ proximal of the bulb and that of the common femoral artery $1 \mathrm{~cm}$ proximal of the bifurcation into the profound and superficial branches. Simultaneously with the vascular measurements, blood pressure was recorded at 3-minute intervals at the right upper arm with a semi-automated device (Dinamap 845, Applied Medical Reseach Corporation, Tampa, FL). The same operator (E.J.B.) measured offline the distances from the adventitia-media boundary of the near wall to the lumen-intima and media-adventitia interfaces of the far wall. ${ }^{15}$ The intimamedia thickness was computed as the mean difference between these distances measured over 3 separate intervals of 5.2 seconds, which on average included 15 heart cycles. An atherosclerotic plaque was defined as a distinct area where the intima-media encroached into the vessel lumen and where its thickness was at least $50 \%$ greater than that of the adjacent sites. ${ }^{16}$ When present, atheromatous plaques were included in the measurements of intima-media thickness. Repeatability was determined in 10 subjects as previously described. ${ }^{15}$ For the carotid intima-media thickness, the repeatability coefficients were $29 \mu \mathrm{m}$ below age 40 years and $40 \mu \mathrm{m}$ in older subjects. For the femoral artery, these coefficients were $41 \mu \mathrm{m}$ and $46 \mu \mathrm{m}$, respectively. For all ages combined, the intra-observer intrasession 
coefficients of variance ${ }^{17}$ amounted to $( \pm$ SD) $5.2 \pm 1.7 \%$ for the common carotid artery and to $5.6 \pm 4.6 \%$ for the femoral artery.

Determination of genotypes

Genomic DNA was extracted from peripheral blood. The ACE I/D polymorphism was detected, as described by Lindpaintner et al. ${ }^{18}$ All samples initially genotyped as $D D$ underwent a second polymerase chain reaction (PCR) with insertion-specific primers. ${ }^{18,19}$

Allelic discrimination of the Gly460Trp $\alpha$-adducin polymorphism was carried out using a 5 ' nuclease assay ${ }^{20}$ on an ABI Prism 7700 apparatus (Perkin Elmer, Norwalk, CT). The forward and reverse primers and the 460Gly and 460Trp probes employed in the TAQMan assay were5'-

CGTCCACACCTTAGTCTTCGACTT-3',

5'-GGAGAAGACAAGATGGCTGAACTC-3', 5'-FAM-

TTCCATTCTGCCCTTCCTCGGA-TAMRA-3' and 5'-TET-

TTCCATTCTGCCATTCCTCGGAA-TAMRA-3', respectively. Per $25 \mu \mathrm{L}$, the PCR fluid contained $50 \mathrm{ng}$ DNA, $300 \mathrm{nmol}$ primers, $100 \mathrm{nmol}$ FAM-probe and $50 \mathrm{nmol}$ TET-probe. The amplification conditions were $50^{\circ} \mathrm{C}$ for 2 minutes, $95^{\circ} \mathrm{C}$ for 10 minutes, $95^{\circ} \mathrm{C}$ for 15 seconds and $62^{\circ} \mathrm{C}$ for 1 minute for 40 cycles.

For determination of the $C-344 T$ aldosterone synthase gene variants, PCR and subsequent genotyping were performed as described by Brand et al. ${ }^{21}$

Statistical methods

For statistical analysis we used SAS version 8.1 (SAS Institute, Cary, NC) and StatXact version 4.01 (Cytel Software Corporation, Cambridge, MA). Comparisons of means and proportions were performed with the standard normal z-test and Fisher's exact test, respectively. Significant covariables of intima-media thickness were traced by stepwise linear regression. $P$-values for independent explanatory variables to enter and to stay in the model were set at $\sim 0.15$. The presence of atheromatous plaques in relation to genotype was studied by multiple logistic regression. In multiple linear and logistic regression, the genotypes were first represented by dummy variables using the deviation from mean coding approach, ${ }^{22}$ which does not imply any genetic hypothesis. In single-gene analyses in which we tested independent hypotheses, we adjusted the $\alpha$-levels and confidence intervals for multiple testing, using Bonferroni's method. ${ }^{23}$ To formally test our prior hypothesis of genetic interactions between the three candidate genes, ${ }^{1-3}$ we also defined dummy variables coded according to the absence or presence of the risk conferring alleles ACE D, $\alpha$-adducin 460Trp, and aldosterone synthase $-344 T$. Because family members are more likely to share identical alleles than randomly selected subjects and to allow for the non-independence of the arterial phenotypes within families, we repeated our analysis using generalized 
estimating equations ${ }^{24}$ as implemented in the PROC GENMOD procedure ${ }^{25}$ of the SAS package. In these analyses, we treated families as clusters and we applied a user-defined working correlation matrix, based on the intrafamilial intraclass correlation coefficients observed in our study subjects.

Results

Characteristics of the participants

The 380 participants included 188 men (49.5\%) and 115 hypertensive patients $(30.3 \%)$, of whom 47 were on one or more blood pressure lowering drugs. Antihypertensive treatment included diuretics in 19 patients, drugs inhibiting the renin system in 12 subjects $(n=10$ for angiotensin converting-enzyme inhibitors, and $n=2$ for angiotensin type- 1 receptor blockers), $\beta$-blockers in 22 patients, and vasodilators in 7 patients $(n=5$ for calcium-channel blockers, and $n=2$ for $\alpha$-blockers). Overall, 18 subjects were taking lipid lowering drugs. The daytime ambulatory blood pressure averaged $124.8 \pm 9.9 \mathrm{~mm} \mathrm{Hg}$ systolic and $75.0 \pm 7.9 \mathrm{~mm} \mathrm{Hg}$ diastolic in men. In women, these levels were $121.6 \pm$ $10.5 \mathrm{~mm} \mathrm{Hg}$ and $73.6 \pm 7.6 \mathrm{~mm} \mathrm{Hg}$, respectively. Of 68 untreated hypertensive patients, $47(69.1 \%)$ had white-coat hypertension.

The subjects ranged in age from 12 to 76 years (Table 1). Carotid and femoral intima-media thickness increased with age (Fig. $1, P<0.001$ ). Carotid or femoral atheromatous plaques were present in 16 men (8.6\%) and 12 women (6.2\%). Among men, 57 (30.3\%) were current smokers and $120(63.8 \%)$ reported intake of alcohol. In women, these numbers were $48(25.0 \%)$ and 72 $(37.5 \%)$, respectively. 17 women $(8.9 \%)$ used oral contraceptives and none took hormonal replacement therapy. 
Stepwise regression analysis identified gender, age, body-mass index, mean arterial pressure, current smoking, serum LDL-cholesterol concentration, and use of antihypertensive medications as likely or significant determinants of the intima-media thickness of the carotid artery, femoral artery, or both (Table 2). Because the correlation coefficient between carotid and femoral intima-media thickness was $0.33(P<0.001)$, we adjusted all analyses for the aforementioned covariables.

The $P$-value for the t-to-enter of lipid lowering treatment was 0.51 for the carotid artery and 0.005 for the femoral artery. However, the regression coefficients $( \pm \mathrm{SE}$ ) for current use of lipid lowering drugs (coded 0 or 1 ) were positive $(27.0 \pm 40.4$ and $180.8 \pm 64.1)$ and therefore reflected bias-byindication. Furthermore, the $P$-values for the t-to-enter were 0.29 or larger for the presence of white-coat hypertension and blood glucose concentration. Sensitivity analyses showed that accounting for the latter three variables did not affect our conclusions. Therefore, in the present analysis, we did not allow for these covariables.

The frequencies of the ACE $(P=0.37), \alpha$-adducin $(P=0.84)$ and aldosterone synthase $(P=0.16)$ genotypes did not deviate from Hardy-Weinberg equilibrium. After adjustment for the aforementioned covariables, the relative risk of having atheromatous plaques was similar across all genotypes, regardless of whether single-gene effects or genetic interactions were tested (Table 3). 
Intima-media thickness

Both before (Fig. 2) and after adjustment for the above covariates, intimamedia thickness of the femoral - but not carotid - artery was significantly associated with ACE genotype. For both arteries, none of the single-gene associations with the $\alpha$-adducin or aldosterone synthase genotypes reached statistical significance.

In a further step of the adjusted analysis, we observed that the effect of the $A C E$ genotype on femoral intima-media thickness was confined to carriers of the $\alpha$-adducin $460 T r p$ allele or the aldosterone synthase $-344 T$ allele. In the presence of the 460Trp allele, the mean intima-media thickness was $59 \mu \mathrm{m}$ lower than the population mean in II homozygotes of the ACE gene, whereas in $D D$ homozygotes it was on average $86 \mu \mathrm{m}$ higher than the population mean (Fig. 3). In carriers of the aldosterone synthase $-344 T$ allele, the corresponding deviations from the population mean amounted to $-48 \mu \mathrm{m}$ and $73 \mu \mathrm{m}$ (Fig. 4). In the presence of both the $\alpha$-adducin 460Trp and aldosterone synthase $-344 T$ alleles, these quantities were $-52 \mu \mathrm{m}$ and $123 \mu \mathrm{m}$, respectively (Fig. 5). Expressed as a percentage of the mean femoral intimamedia thickness in the whole population, the differences between the II and $D D$ homozygotes averaged $13.4 \%(95 \% \mathrm{Cl} 5.6-21.2 \%)$ in all subjects, $21.2 \%$ $(8.0-34.5 \%)$ in carriers of the $\alpha$-adducin 460 Trp allele, $15.4 \%(4.1-26.8 \%)$ in subjects having the aldosterone synthase $-344 T$ allele, and $25.2 \%$ (10.7 $39.7 \%$ ) if the latter alleles were both present.

We obtained similar results if we excluded 28 subjects with plaques at any arterial site (carotid or femoral). In this restricted sample, the differences between II and $D D$ homozygotes averaged 11.7\% (4.7 - 18.7\%). In 150 carriers of the $\alpha$-adducin $460 T r p$ allele, in 279 carriers of the aldosterone synthase $-344 T$ allele, and in 123 carriers of both the 460Trp and -344T alleles, the differences between the $/ I$ and $D D$ homozygotes in the restricted 
group amounted to $18.3 \%(6.2-30.5 \%), 13.8 \%$ (3.6 - 24.0\%) and $22.8 \%(9.4$ $-36.2 \%)$, respectively.

Furthermore, we also confirmed our results after additional allowance for the non-independence of the intima-media thickness phenotype within families. The differences between the $/ I$ and $D D$ homozygotes averaged $12.5 \%(95 \% \mathrm{Cl}$ $3.7-21.3 \% ; P=0.005)$ in all subjects, $22.5 \%(7.0-38.1 \% ; P=0.005)$ in carriers of the $\alpha$-adducin 460Trp allele, $12.9 \%(1.2-4.6 \% ; P=0.03)$ in subjects having the aldosterone synthase $-344 T$ allele, and $27.5 \%(9.9-$ $45.6 \% ; P=0.003$ ) if the latter alleles were both present.

In further regression analyses in all subjects, the $\alpha$-adducin and aldosterone synthase genotypes were represented by dummy variables coded 0 or 1 depending on the absence or presence of the 460Trp and -344T alleles and the ACE genotypes were coded as 0,1 or 2 according to the number of $D$ alleles. The 3-way interaction terms for the carotid and femoral arteries had $P$ values of 0.76 and 0.045 , respectively. 


\section{Discussion}

In proximal elastic arteries hypertrophy of the wall is a marker of atherosclerosis, predominantly due to intima thickening, whereas in large or middle-sized muscular arteries this phenomenon mainly reflects remodelling of the media. ${ }^{26}$ To the best of our knowledge, our study provides the first evidence of a synergism between the genes encoding ACE, $\alpha$-adducin and aldosterone synthase in relation to the intima-media thickness of the femoral artery. The mean differences between I/ and $D D$ homozygotes of the ACE gene, expressed as a percentage of the population mean, amounted to $13.4 \%$ in all subjects. These differences averaged $21.2 \%, 15.4 \%$ and $25.2 \%$, respectively, if the $\alpha$-adducin $460 T r p$ allele, the aldosterone synthase $-344 T$ allele, or both alleles, were present. Less phenotypic precision when a dichotomous trait replaces a continuous one and the small number of cases $(n$ $=28$ ), probably explain our null findings with regard to the presence of atheromatous plaques. Because of the sample size required, ${ }^{1}$ we did not consider blood pressure as an outcome variable in the present 380 subjects.

Few studies ${ }^{27,28}$ reported on the genetic factors influencing femoral intimamedia width and no investigator has found a significant and positive association with the ACE $D$ allele. Several studies ${ }^{27-34}$ specifically addressed the possible relationship between the ACE I/D polymorphism and carotid intima-media thickening. Most studies ${ }^{29,31-33}$ reported negative results. In the Vobarno population study, the ACE $D$ allele was found to be associated with carotid intima-media thickening, but not with the presence of carotid atherosclerotic plaques. ${ }^{30}$ In a Finnish population study, non-smoking $D D$ homozygotes had a significantly greater carotid intima-media thickness than did those with the $/ /$ or $I D$ genotypes ${ }^{35}$ In the total population, this association was weaker and it was reported to be absent in current smokers. In Japanese subject, ${ }^{36}$ a positive correlation has been observed between the $D$ allele and the presence of carotid plaques. In Chinese hypertensive subjects, ${ }^{34}$ a positive correlation was observed between the $D$ allele and carotid intima-media thickening, but not with left ventricular hypertrophy. Two quantitative reviews of the available literature ${ }^{37,38}$ also found significant associations between major atherosclerotic complications and the presence of the ACE $D$ allele. However, no association between cardiovascular disease and the $A C E \quad I / D$ polymorphism was reported in a meta-analyses of studies in whites. ${ }^{39}$ Some studies of the carotid artery included genetic variants other than the $A C E I / D$ polymorphism, such as the M235T polymorphism of the angiotensinogen gene $^{33}$ or the $A 1166 C$ polymorphism of the angiotensin-II receptor gene. ${ }^{31}$ However, no study formally tested for synergism between these candidate genes in relation to intima-media thickness or the presence of atherosclerosis. Our findings concerning the femoral intima-media thickness are in line with the blood pressure results in a cross-sectional analysis of 1461 subjects drawn from the same population. ${ }^{1}$ Systolic blood pressure and the prevalence of hypertension were significantly elevated among subjects who carried both the 
$\alpha$-adducin 460Trp allele and the aldosterone synthase $-344 T$ allele. In a recently published case-control study, ${ }^{40}$ a similar trend

$(P=0.10)$ was observed in as few as 129 hypertensive patients and 129 normotensive controls. The presence of the ACE $D$ allele is associated with higher systemic ACE levels. ${ }^{4}$ which probably stimulate the local generation of angiotensin II. ${ }^{5}$ This may promote intima-media thickening. Hypertensive patients carrying the $\alpha$-adducin 460Trp allele, compared with those having the wild-type Gly460 variant, show an enhanced proximal tubular renal reabsorption of sodium ${ }^{41}$ and experience larger blood pressure changes in response to sodium loading or diuretic treatment. ${ }^{19,41,42}$ The presence of the $344 T$ allele at the $C-344 T$ locus in the promoter area of the aldosterone synthase gene stimulates aldosterone synthesis independently of the regulation by angiotensin II and potassium. ${ }^{43}$ The mutated $\alpha$-adducin and high aldosterone secretion, both acting through sodium retention, may possibly lead to chronic expansion of the extracellular fluid volume and increased blood pressure and may, via these intermediary mechanisms, induce compensatory structural changes in the wall of large muscular arteries.

Williams et al. ${ }^{44}$ examined the interactions between 7 polymorphic genetic markers at 4 candidate loci in relation to hypertension. In single-gene analyses, there were no significant differences between normotensive and hypertensive subjects with respect to either allele or genotype frequencies. However, of 120 multilocus haplotypes, the distribution of 16 non-allelic combinations deviated significantly from random in the hypertensive patients, whereas among normotensive subjects no linkage disequilibrium was observed. This report, ${ }^{44}$ in line with our present and previous findings, ${ }^{1-3}$, suggests that genetic interactions between multiple loci rather than single genes make up the genetic basis of cardiovascular disease and probably explain the inconsistencies between single-gene studies. Furthermore, crosssectionally and longitudinally measured phenotypes of the same trait, for instance blood pressure, may differ in their apparent genetic determination. ${ }^{1}$ Environmental factors modulate the effects of the inherited genetic code. Genetic interactions may result in pleiotrophic effects according to the involved tissue type, as for instance in the present paper the intima-media of elastic as opposed to muscular arteries. These factors add further complexity to the genetic determination of multigenic cardiovascular disorders. Molecular biology may help bridging the gap between DNA sequencing and pathophysiological mechanisms and elucidate how cardiovascular disorders come about. For instance, further in-vitro studies should clarify whether the stimulation of the sodium pump in carriers of the $\alpha$-adducin 460Trp allele is confined to renal tubular cells ${ }^{41,42}$ or is ubiquitously present, in particular in vascular smooth muscle cells. The actively regulated intracellular $\mathrm{Na}^{+}$ concentration may modulate the availability of free $\mathrm{Ca}^{2+}$ ions, which enhances contractility and stimulate cell growth. ${ }^{45,46}$

If confirmed, our findings may have important clinical implications for the assessment of cardiovascular risk and the treatment of hypertension. Indeed, in the Angina Prognosis Study ${ }^{9}$ carotid and femoral intima-media thickening 
and femoral plaques predicted the incidence of cardiovascular death and myocardial infarction and the need of revascularization procedures in unadjusted analyses involving 809 patients with coronary artery disease. After adjustment for sex, age, smoking, previous cardiovascular disease and lipid status, the risk of revascularization remained correlated with femoral intimamedia thickness and the presence of atherosclerotic plaques in the femoral artery. After adjustment for the same covariables, carotid intima-media thickness failed to predict any cardiovascular event, but the presence of carotid plaques predicted $(P=0.056)$ the risk of cardiovascular death or myocardial infarction.

In conclusion, our findings suggest that intima-media thickness of large muscular arteries, such as the femoral artery, is influenced by synergism between the genes encoding ACE, $\alpha$-adducin and aldosterone synthase.

\section{Acknowledgements}

The Flemish population study would not have been possible without the collaboration of the family physicians of the participants. The municipality Hechtel-Eksel (Belgium) provided logistic support. The authors acknowledge the expert assistance of Leszek Bieniaszewski MD, Rina Bollen, Lut De Pauw RN, Hilde Celis MD, Primoz Dolenc MD, Paul Drent, Dmitri Emelianov MD, Jerzy Gasowski MD, Heng Fan, Lieve Gijsbers, Alida Hermans, Tatyana Kuznetsova MD, Tim Nawrot BSC, Agnieszka Olszanecka MD, Valérie Tikhonoff MD, Katarzyna Stolarz MD, Lutgarde Thijs BSC, Yvette Toremans, Sylvia Van Hulle RN, and Renilde Wolfs (Study Coordinating Centre, Leuven, Belgium). Brigitte Egbers (Berlin) determined the aldosterone-synthase genotypes. 
1 Staessen JA, Wang JG, Brand E, Barlassina C, Birkenhäger WH, Herrmann SM, et al. Effects of three candidate genes on prevalence and incidence of hypertension in a Caucasian population. J Hypertens 2001, 19:1349-1358.

2 Wang JG, Staessen JA, Tizzoni L, Brand E, Birkenhäger WH, Fagard R, et al. Renal function in relation to three candidate genes. Am J Kidney Dis 2001, 38:1158-1168.

3 Balkestein EJ, Staessen JA, Wang JG, van der Heijden-Spek JJ, Van Bortel L, Barlassina C, et al. Carotid and femoral artery stiffness in relation to three candidate genes in a white population. Hypertension 2001, 38:1190-1197.

4 Rigat B, Hubert C, Alhenc-Gelas F, Cambien F, Corvol P, Soubrier F. An insertion/deletion polymorphism in the angiotensin l-converting enzyme gene accounting for half the variance of serum enzyme levels. J Clin Invest 1990, 86:1343-1346.

5 Müller DN, Bohlender J, Hilgers KF, Dragun D, Costerousse O, Ménard J, et al. Vascular angiotensin-converting enzyme expression regulates local angiotensin II. Hypertension 1997, 29:98-104.

6 Morishita R, Gibbons GH, Ellison KH, Lee W, Zhang L, Yu H, et al. Evidence for direct local effect of angiotensin in vascular hypertrophy. In vivo gene transfer of angiotensin converting enzyme. J Clin Invest 1994, 94: 978-984.

7 Grobbee DE, Bots ML. Carotid intima-media thickness as an indicator of generalized atherosclerosis. J Intern Med 1994, 236:567-573.

8 O'Leary DH, Polak JF, Kronmal RA, Manolio TA, Burke GL, Wolfson SK, Jr., et al. Carotid-artery intima and media thickness as a risk factor for myocardial infarction and stroke in older adults. N Engl J Med 1999, 340:14-22.

9 Held C, Hjemdahl P, Eriksson SV, Björkander I, Forslund L, Rehnqvist N. Prognostic implications of intima-media thickness and plaques in the carotid and femoral arteries in patients with stable angina pectoris. Eur Heart J 2001, 22:62-72.

10 Staessen JA, Roels HA, Emelianov D, Kuznetsova T, Thijs L, Vangronsveld J, et al. Environmental exposure to cadmium, forearm bone-density, and risk of fractures: prospective population study. Lancet 1999, 353:1140-1144.

11 O'Brien E, Waeber B, Parati G, Staessen J, Myers MG, on behalf of the European Society of Hypertension. Blood pressure measuring devices: recommendations of the European Society of Hypertension. Brit Med J 2001, 322:531-536.

12 Staessen JA, Bieniaszewski L, O'Brien ET, Imai Y, Fagard R. An epidemiological approach to ambulatory blood pressure monitoring: the Belgian population study. Blood Press Monit 1996, 1:13-26.

13 The Joint National Committee on Prevention Detection Evaluation and Treatment of High Blood Pressure. The Sixth report of the Joint National 
Committee on Prevention, Detection, Evaluation, and Treatment of High Blood Pressure. Arch Intern Med 1997, 157:2413-2446. Hoeks APG, Brands PJ, Smeets FAM, Reneman RS. Assessment of the distensibility of superficial arteries. Ultrasound Med Biol 1990, 16:121128.

Willekes C, Hoeks APG, Brands PJ, Williger JM, Reneman RS.

Evaluation of off-line automated intima-media thickness detection of the common carotid artery based on M-line signal processing. J Vasc Res 1999, 36:222-228.

16 Salonen JT, Salonen R. Ultrasound B-mode imaging in observational studies of atherosclerotic progression. Circulation 1993, 87 (suppl II):II57-II-65.

17 Kool MJF, van Merode T, Reneman RS, Hoeks APG, Struijker Boudier HAJ, Van Bortel L. Evaluation of reproducibility of a vessel wall movement detector system for assessment of large artery properties. Cardiovasc Res 1994, 28:610-614.

18 Lindpaintner K, Pfeffer MA, Kreutz R, Stampfer MJ, Grodstein F, LaMotte $F$, et al. A prospective evaluation of an angiotensin-converting-enzyme gene polymorphism and the risk of ischemic heart disease. N Engl J Med 1995, 332:706-711.

19 Barlassina C, Norton GR, Samani NJ, Woodwiss AJ, Candy GC, Radevski I, et al. $\alpha$-Adducin polymorphism in hypertensives of South African ancestry. Am J Hypertens 2000, 13:719-723.

20 Livak KJ, Flood SJ, Marmaro J, Giusti W, Deetz K. Oligonucleotides with fluorescent dyes at opposite ends provide a quenched probe system useful for detecting PCR product and nucleic acid hybridization. PCR Methods Appl 1995, 4:357-362.

21 Brand E, Chatelain N, Mulatero P, Féry I, Curnow K, Jeunemaitre X, et al. Structural analysis and evaluation of the aldosterone synthase gene in hypertension. Hypertension 1998, 32:198-204.

22 Hosmer DW, Jr., Lemeshow S. Interpretation of coefficients. In Applied Logistic Regression,Applied Logistic Regression. New York, NY, USA: John Wiley \& Sons; 1989:38-81.

23 Bland JM, Altman DG. Multiple significance tests: the Bonferroni method. Brit Med J 1995, 310:170.

24 Trégouët DA, Ducimetière $P$, Tiret $L$. Testing associations between candidate-gene markers and phenotype in related individuals by use of estimating equations. Am J Hum Genet 1997, 61:189-199.

25 The SAS Institute. The GENMOD procedure. In SAS Online Doc Version 7.1: SAS/STAT, SAS Online Doc Version 7.1. Cary, NC, USA; 2000:1311-1411.

26 Girerd X, Mourad JJ, Copie X, Moulin C, Acar C, Safar M, et al. Noninvasive detection of an increased vascular mass in untreated hypertensive patients. Am J Hypertens 1994, 7:1076-1084.

27 Hosoi M, Nishizawa Y, Kogawa K, Kawagishi T, Konishi T, Maekawa K, et al. Angiotensin-converting enzyme gene is associated with carotid 
arterial wall thickness in non-insulin-dependent diabetic patients.

Circulation 1996, 94:704-707.

28 Kogawa K, Nishizawa Y, Hosoi M, Kawagishi T, Maekawa K, Shoji T, et al. Effect of polymorphism of apolipoprotein $E$ and angiotensin-converting enzyme genes on arterial wall thickness. Diabetes 1997, 46:682-687.

29 Dessì-Fulgheri P, Catalini R, Sarzani R, Sturbini S, Siragusa N, Guazzarotti F, et al. Angiotensin converting enzyme gene polymorphism and carotid atherosclerosis in a low-risk population. J Hypertens 1995, 13:1593-1596.

30 Castellano M, Mulesan ML, Rizzoni D, Beschi M, Pasini G, Cinelli A, et al. Angiotensin-converting enzyme $\mathrm{l} / \mathrm{D}$ polymorphism and arterial wall thickness in general population. The Vobarno study. Circulation 1995, 91:2721-2724.

31 Girerd X, Hanon O, Mourad JJ, Boutouyrie P, Laurent S, Jeunemaitre X. Lack of association between renin-angiotensin system, gene polymorphisms, and wall thickness of the radial and carotid arteries. Hypertension 1998, 32:579-583.

32 Huang XH, Loimaala S, Nenonen A, Mercuri M, Vuori I, Pasanen M, et al. Relationship of angiotensin-converting enzyme gene polymorphism to carotid artery wall thickness in middle-aged men. J Mol Med 1999, 77:853-858.

33 Arnett DK, Borecki IB, Ludwig EH, Pankow JS, Myers R, Evans G, et al. Angiotensinogen and angiotensin converting enzyme genotypes and carotid atherosclerosis: the atherosclerotic risk in communities and the NHLBI family heart studies. Atherosclerosis 1998, 138:111-116.

34 Jeng JR. Carotid thickening, cardiac hypertrophy, and angiotensin converting enzyme gene polymorphism in patients with hypertension. Am J Hypertens 2000, 13:111-119.

35 Kauma H, Päivänsalo M, Savolainen MJ, Rantala AO, Kiema TR, Lilja M, et al. Association between angiotensin converting enzyme gene and polymorphism and carotid atherosclerosis. J Hypertens 1996, 14:11831187.

36 Watanabe $\mathrm{Y}$, Ishigami T, Kawano Y, Umahara T, Nakamori A, Mizushima $\mathrm{S}$, et al. Angiotensin-converting enzyme gene I/D polymorphism and carotid plaques in Japanese. Hypertension 1997, 30 (part 2):569-573.

37 Samani NJ, Thompson JR, O'Toole L, Channer K, Woods KL. A metaanalysis of the association of the deletion allele of the angiotensinconverting enzyme with myocardial infarction. Circulation 1996, 94:708712.

38 Wang JG, Staessen JA. Genetic polymorphisms in the renin-angiotensin system: relevance for susceptibility to cardiovascular disease. Eur $J$ Pharmacol 2001, 410:289-302.

39 Agerholm-Larsen B, Nordestgaard BG, Tybjærg-Hansen A. ACE gene polymorphism in cardiovascular disease. Meta-analysis of small and large studies in whites. Arterioscler Thromb Vasc Biol 2000, 20:484-492. 
40 Clark CJ, Davies E, Anderson NH, Farmer R, Friel E, Fraser R, et al. $\alpha$ Adducin and angiotensin I-converting enzyme polymorphisms in essential hypertension. Hypertension 2000, 36:990-994.

41 Bianchi G, Cusi D. Association and linkage analysis of $\alpha$-adducin polymorphism: is the glass half full or half empty? Am J Hypertens 2000, 13:739-743.

42 Barlassina C, Schork NJ, Manuta P, Citterio L, Sciarrone MT, Lanella G, et al. Synergistic effect of $\alpha$-adducin and ACE genes causes blood pressure changes with body sodium and volume expansion. Kidney Int 2000, 57:1083-1090.

43 Clyne CD, Zhang Y, Slutsker L, Mathis JM, White PC, Rainey WE. Angiotensin II and potassium regulate human CYP11B2 transcription through common cis elements. Mol Endocrinol 1997, 11:638-649.

44 Williams SM, Addy JH, Phillips JAI, Dai M, Kpodonu J, Afful J, et al. Combinations of variations in multiple genes are associated with hypertension. Hypertension 2000, 36:2-6.

45 Blaustein MP, Hamlyn JM. Pathogenesis of essential hypertension. A link between dietary salt and high blood pressure. Hypertension 1991, 18:III184-III-195.

46 Blaustein MP, Hamlyn JM. Sodium transport inhibition, cell calcium, and hypertension. The natriuretic hormone $/ \mathrm{Na}^{+}-\mathrm{Ca}^{2+}$ exchange/hypertension hypothesis. Am J Med 1984, 77: 45-59. 
Chapter 7

General Discussion 
Cardiovascular risk factors

Cardiovascular diseases are the leading cause of mortality and morbidity in the world. This explains why cardiovascular risk factors remain a major topic for research. Smoking, gender, obesity, metabolic disorders and blood pressure are traditional risk factors, which have been intensively investigated in population surveys. ${ }^{1}$ Over the last decades, the list of risk factors was extended with large artery stiffness, a major determinant of pulse pressure. ${ }^{2}$ Reports on the relationship between prognosis, stiffness of large arteries and pulse pressure are contradictary, ${ }^{3-7}$ possibly because in most reports the genetic background of the subjects studied was not accounted for.

The appearance of cardiovascular genetics as a medical discipline has led to the publication of numerous studies conducted in animals as well as in humans, in search for specific genetic mutations which either cause cardiovascular disease in a monogenic or polygenic fashion or predispose subjects to various cardiovascular disorders. ${ }^{8-11}$ One of the major systems involved in the regulation of blood pressure is the renin-angiotensinaldosterone system (RAAS). The genes encoding for its constituents, such as renin, angiotensinogen, angiotensin-converting enzyme, aldosterone and angiotensin II type 1 receptor are important candidate genes. However, other genes may act on targets which are also influenced by the RAAS, such as the epithelial amiloride-sensitive sodium channel ( $\alpha, \beta$ and $\gamma$ subunits) and $\alpha$-adducin.

Angiotensinogen polymorphisms were among the first to be associated with hypertension, ${ }^{12}$ but not all studies have confirmed this association. ${ }^{13,14}$ The angiotensin-converting enzyme polymorphism (ACE I/D) is one of the gene variants which has been considered in different populations to be associated with various manifestations of cardiovascular disease. ${ }^{15-18}$ The role of this gene in predisposing to cardiovascular disease is still controversial. The angiotensin II type 1 receptor has also been associated with cardiovascular disease by some, ${ }^{19}$ but not all investigators. ${ }^{16}$

Furthermore, the aldosterone synthase gene has been frequently investigated after the discovery of the genetic cause of 'glucocorticoid-remediable hyperaldosteronism'. With respect to the aldosterone synthase gene polymorphism $(C-344 T)$, both positive ${ }^{20,21}$ and null associations ${ }^{22-24}$ with cardiovascular disease have been reported. ${ }^{16}$

Genes which play a role in sodium handling are also important in hypertension research. Polymorphisms of the thiazide-sensitive $\mathrm{NaCl}$-cotransporter play a causative role in Gitelman's syndrome, an autosomal recessive disease characterized by sodium wasting, low blood pressure and secondary hyperaldosteronism. ${ }^{25}$ Mutations in the $\beta$-or $\gamma$-subunit of the epithelial amiloride-sensitive sodium channel are responsible for hypertension in Liddle's syndrome. ${ }^{26}$ 
The 460Trp allele of the $\alpha$-adducin gene is associated with hypertension and sodium retention in the Milan rat strain. ${ }^{27}$ However, population studies and case-control studies have thus far not shown a uniform relationship between this polymorphism and hypertension ${ }^{28,29}$ or other manifestations of cardiovascular disease..$^{30}$

With respect to structural and functional characteristics of large arteries, the genes studied are those encoding aldosterone synthase, angiotensinconverting enzyme, angiotensin II type 1 receptor and angiotensinogen. ${ }^{19,31-34}$ To date, the results of these studies remain contradictory.

Gene-Gene interaction

Different outcomes of studies on the association of polymorphisms and cardiovascular disease might be a result of the fact that mostly single gene effects are considered. Epistatic interactions of genes should be considered $^{35,36}$ and might be illustrative in the description of the multifactorial model of a cardiovascular disease like hypertension. ${ }^{36}$ Already in 1995 Lifton described these possible gene-gene and gene-environment interactions (figure 1). One can further complicate this model with for instance the gene-body mass interaction, as recently decribed ${ }^{37}$ for the $\alpha$-adducin Gly460Trp polymorphism and the gene-gender or gene-ethnicity interactions of the ACE I/D polymorphisms. ${ }^{38-40}$ 


\section{Main results of our research}

Mean blood pressure, as a result of systemic vascular resistance index and cardiac index is marked differently when the ACE $I / D$ genotypes are considered in view of the genetic background of the $\alpha$-adducin Gly460Trp polymorphism. In ACE DD subjects, mean blood pressure is marked by a high systemic vascular resistance and a low cardiac index (low stroke index) if these individuals are homozygous for the Gly460 allele of the $\alpha$-adducin gene. Furthermore, these subjects have a decreased distensibility and compliance of the muscular femoral artery as compared to their ACE DD counterparts, carrying the 460Trp allele for

$\alpha$-adducin. The latter subjects also have an increased intima media thickness of the femoral artery. At the common carotid artery intima media thickness does not differ across these genotypes, nor does distensibility or compliance.

Functional parameters at the level of the common carotid artery were different when the ACE I/D genotypes were considered in combination with the C-344T aldosterone synthase genotype. The increased diameter of the common carotid artery and an unchanged compliance in ACE DD subjects carrying the $-344 T$ allele, resulted in a lower distensibility of this artery.

Interpretation and hypothesis

We chose to investigate polymorphisms in the genes encoding angiotensinconverting enzyme, aldosterone synthase and $\alpha$-adducin, because these gene products all have the potential to influence sodium handling and consequently circulating blood volume. However, the possible mechanism by which these three genes jointly act on different phenotypes is not clear. One could hypothesize that all effects are adaptive to an increase in the circulating volume due to the enhanced reabsorption of sodium. In response to the increase in volume and consequently circumferential wall stress, the vessel wall may hypertrophy. According to Lamé's equation (circumferential wall stress=mean blood pressure*internal diameter/(2*imt), this adaptive process will lead to a decrease in wall stress without a change in blood pressure. The increased vascular smooth muscle cell mass, which we observed in association with the ACE $D$ allele in carriers of the $\alpha$-adducin 460Trp allele, could explain the greater compliance and distensibility without a change in diameter of the femoral artery. We did not observe a parallel increase in the intima-media thickness of the common carotid artery. It is possible that in an elastic artery the muscular layer is not sufficiently developed to compensate for the increase in circulatory volume. Such mechanism would explain the larger carotid artery diameter in ACE DD subjects who also carried the aldosterone synthase $-344 T$ allele and the consequently decreased carotid distensibility without a change in compliance.

Subjects with the ACE DD genotype have a higher systemic vascular resistance and lower cardiac index when homozygous for the Gly460 allele of 
$\alpha$-adducin as compared to $A C E D D$ subjects carrying the $460 T r p$ allele. The latter phenomenon points in a direction of a feed back mechanism involving the RAA system and sodium handling by the $\alpha$-adducin protein.

The observations that the interactions among the three candidate genes were apparently heterogenous along the arterial tree suggests that our results should not only be explained by an adaptive process, but may also be mediated, at least in part, by primary alterations in the function of cells which make up the wall of large arteries (figure 2). 
One assumption, which can be reasonably made on the basis of published data is that as the concentration and activity of the angiotensin converting enzyme increases with the number of ACE $D$ alleles, also the local and paracrine generation of angiotensin II rises. This octapeptide is a major determinant of many cell functions. Furthermore, one must keep in mind that the common carotid artery is a predominantly elastic artery, with a relatively large amount of matrix material in its three layered structure, whereas the femoral artery is a predominantly muscular artery.

A second assumption in our hypothesis is that the enhanced activity of the $\mathrm{Na}^{+} / \mathrm{K}^{+}$pump by the 460Trp allele, is not only expressed at renal tubular cells, but may also affect vascular smooth muscle cells.

In our opinion the following might happen in a muscular artery when both the ACE $D$ allele and the $\alpha$-adducin 460Trp allele are present.

The ACE $D$ allele leads to an increased local generation of angiotensin II. This peptide activates the $\mathrm{Na}^{+} / \mathrm{H}^{+}$exchanger, which in turn leads to a greater availability of free $\mathrm{Ca}^{2+}$ ions and intracellular alkalization. The greater availibility of free $\mathrm{Ca}^{2+}$ could also be due to an increased activity of the $\mathrm{Na}^{+} / \mathrm{Ca}^{2+}$ cotransporter, or could be induced by modulation of the $\mathrm{Na}^{+}$ dependent $\mathrm{Mg}^{2+}$ transport. ${ }^{41}$ Intracellular $\mathrm{Mg}^{2+}$ will be reduced, reducing the $\mathrm{Ca}^{2+}$ inhibiting effects of $\mathrm{Mg}^{2+}$, which results in increased intracellular $\mathrm{Ca}^{2+}$, increased vascular tone and hypertrophy of vascular smooth muscle cells. This mechanism has been described in spontaneously hypertensives rats. ${ }^{41}$ Intracellular $\mathrm{Na}^{+}$is increased in the presence of the 460Trp allele, by an increased activity of the $\mathrm{Na}^{+} / \mathrm{K}^{+}$pump. The increased aldosterone levels seen in carriers of the aldosterone synthase $-344 T$ allele, acting on the $\mathrm{Na}^{+} / \mathrm{K}^{+}$ pump, could further increase intracellular $\mathrm{Na}^{+}$.

These three polymorphisms can ultimately lead to an increased intracellular $\mathrm{Na}^{+}$content by different pathways and will lead to increased free $\mathrm{Ca}^{2+}$. This central role for $\mathrm{Na}^{+}$coupled to $\mathrm{Ca}^{2+}$ in the origin for essential hypertension besides the role of volume expansion, has already been described a long time ago. ${ }^{42}$

In 1984 Blaustein wrote:'The possibility that intracellular sodium is elevated in various types of cells in hypertensive patients is particularly intriguing: such a defect in vascular smooth muscle cells could promote calcium entry and thereby help to explain the increased vascular tone and reactivity that produces the elevated blood pressure.

The increase in vascular smooth muscle cell mass as a result of increased intracellular $\mathrm{Ca}^{2+}$ as proposed above, will lead to decreased stiffness. This decrease could overrule the direct effect of angiotensin II on the matrix of the muscular artery, which would be an increase in stiffness. The overall effect, a decrease in stiffness, will be an increase in compliance, resulting in an increase in distensibility, due to an unchanged diameter. The latter indicates 
that the hypertrophy counteracts the possible diameter enlargement due to an expanded circulating volume.

The fact that this does not happen when combining the ACE I/D and aldosterone synthase genotypes points to a more dominant or stronger effect of the $\alpha$-adducin genotype, which is supported by the fact that the latter genotype in combination with the ACE D allele shows a larger increase in intima media thickness of the femoral artery. The difference between ACE II and $A C E D D$ homozygotes was $21.4 \%$, expressed as a percentage of the population mean, when carrying the $460 T r p$ allele, as compared to $15.4 \%$ in those homozygotes carrying the aldosterone synthase -344T allele.

At the level of the carotid artery we again assume, that angiotensin II levels are increased with an increased stiffness of the arterial wall. Since the carotid artery is composed of relatively more extracellular matrix material as compared to the muscular femoral artery, this stiffening effect will not be compensated or overruled by an increase in vascular smooth muscle cell mass. The decreased distensibility due to an increased diameter in ACE DD homozygotes, when carrying the aldosterone $-344 T$ allele, are indicative of a primary effect of the ACE-aldosterone interaction on proximal tubular cells with an increase in circulating volume.

With respect to systemic vascular resistance one might hypothesize that the local effect of angiotensin II on small resistance arteries (vasoconstriction) will lead to an increased total resistance. This increase would lead to an increase in mean arterial pressure if cardiac output were to remain equal. In those subjects homozygous for the $\alpha$-adducin Gly460 allele, cardiac output (stroke volume) is decreased, as compared to those with the $\alpha$-adducin 460Trp allele, which leads to an unchanged mean arterial pressure. The presence of the $\alpha$-adducin 460Trp allele appears to antagonize the pressor effect of the renin angiotensin aldosterone system by an increased circulating volume. The original data presented by Barlassina and co-workers on the synergistic effect of $\alpha$-adducin and ACE genes provides evidence for this antagonizing effect. The plasma renin activity was markedly lower in subjects carrying the 460Trp or $A C E D$ allele. In line with these findings is the observation of in Liddle's syndrome, where the gain of function mutation in the EnaC complex, leading to $\mathrm{Na}^{+}$reabsorption, leads to suppression of plasma renin activity. One can argue that the gain of function in the $\alpha$-adducin dimer in the presence of the 460Trp allele, with an enhanced sodium reabsorption, will lead to a comparable suppression of the plasma renin activity. 


\section{Future research}

Our findings may have important clinical implications, because on the basis of our present findings the ACE $D$, the $\alpha$-adducin 460Trp and the aldosterone synthase $-344 T$ allele, may be considered as increasing a subjects cardiovascular risk. Indeed, in the presence of these genetic variants, we observed

i) intima-media thickening of the femoral artery, a precursor of atherosclerosis and a known predictor of cardiovascular risk

ii) a decreased distensibility of the carotid artery, also a marker of increased cardiovascular risk

iii) volume-dependent hypertension.

To prove our hypotheses on the specific cellular and pathophysiological mechanisms through which the three candidate genes may influence cardiovascular structure, function and risk, basic laboratory research is warranted. Measurement of cellular $\mathrm{Ca}^{2+}$ handling and possibly the activity of the different $\mathrm{Na}^{+}$channels or exchangers in vascular smooth muscle cells of both risk-allele carrying subjects as opposed to non-risk-allele carriers may provide more insight in the development of hypertension.

Like Blaustein already proposed in 1984 with regard to this kind of research, we conclude that

" this may lead us to the defect that appears to be responsible for the hypertensive process"

Specific tests to measure vascular reactivity, like for instance fore-arm blood flow measurements may possibly shed some light on the mechanisms of total systemic vascular resistance and cardiac output in relation to the three genes.

Furthermore, follow up of our study population and prospective analysis of the incidence of cardiovascular events in relation to the three candidate genes is of major importance. 
1. Kannel WB, McGee D, Gordon T. A general cardiovascular risk profile: the Framingham Study. Am J Cardiol. 1976;38:46-96.

2. Stergiopulos N, Westerhof N. Determinants of pulse pressure. Hypertension. 1998;32:556-559.

3. Amar J, Ruidavets JB, Chamontin B, Drouet L, Ferrieres J. Arterial stiffness and cardiovascular risk factors in a population-based study. $J$ Hypertens. 2001;19:381-387.

4. Dart AM, Kingwell BA. Pulse pressure - A review of mechanisms and clinical relevance. J Am Coll Cardiol. 2001;37:975-984.

5. Franklin SS, Khan SA, Wong ND. Is pulse pressure useful in predicting risk for coronary heart disease? The Framingham Heart Study. Circulation. 1999;10:354-360.

6. Megnien JL, Simon A, Denarie N, Del-Pino M, Gariepy J, Segond P, Levenson J. Aortic stiffening does not predict coronary and extracoronary atherosclerosis in asymptomatic men at risk for cardiovascular disease. Am J Hypertens. 1998;11:293-301.

7. O'Rourke M F, Frohlich E D. Pulse pressure; is this a clinically useful risk factor? Hypertension. 1999;34:372-374.

8. Lifton RP, Gharavi AG, Geller DS. Molecular mechanisms of human hypertension. Cell. 2001;104:545-556.

9. Smithies $\mathrm{O}$, Kom H-S, Takahashi $\mathrm{N}$, Edgell $\mathrm{MH}$. Importance of quantitative genetic variation in the etiology of hypertension. Kidney Int. 2000;58:2265-2280.

10. Luft FC. Molecular genetics of human hypertension. J Hypertens. 1998;16:1871-1878.

11. Milewicz D, Seidman CE. Genetics of cardiovascular disease. Circulation. 2000;102:IV-103-IV-111.

12. Jeunemaitre $X$, Soubrier $F$, Kotelevtsev $Y V$, Lifton RP, Williams CS, Charru A, Hunt SC, Hopkins PN, Williams RR, Lalouel JM, Corvol P. Molecular basis of human hypertension: role of angiotensinogen. Cell. 1992;71:169-180.

13. Larson N, Hutchinson R, Boerwinkle E. Lack of assocation of 3 functional gene variants with hypertension in African americans. Hypertension. 2000;35:1297-1300.

14. Staessen JA, Kuznetsova T, Wang JG, Emelianov D, Vlietinck R, Fagard R. M235T angiotensinogen polymorphism and cardiovascular renal risk. J Hypertens. 1999;17:9-17.

15. Staessen JA, Wang J-G, Ginocchio G, Petrov V, Saavedra AP, Soubrier $F$, Vlietinck R, Fagard R. The deletion/insertion polymorphism of the angiotensin converting enzyme and cardiovascular-renal risk. $J$ Hypertens. 1997;15:1579-1592.

16. Wang J-G, Staessen JA. Genetic polymorphisms in the reninangiotensin system: relevance for susceptibility to cardiovascular disease. Eur J Pharmacol. 2000;410:289-302. 
17. Samani NK, Thompson JR, O'Toole L, Channer K, Woods KL. A metaanalysis of the association of the deletion allele of the angiotensionconverting enzyme gene with myocardial infarction. Circulation. 1996;94:708-712.

18. Agerholm-Larsen B, Nordestgaard BG, Tybjaerg-Hansen A. ACE gene polymorphism in cardiovascular disease. Meta-analyses of small and large studies in whites. Thromb Vasc Biol. 2000;20:484-492.

19. Lajemi M, Labat C, Gautier S, Lacolley P, Safar M, Asmar R, Cambien $\mathrm{F}$, Benetos A. Angiotensin II type 1 receptor ${ }^{-153} \mathrm{~A} / \mathrm{G}$ and ${ }^{1166} \mathrm{~A} / \mathrm{C}$ gene polymorphisms and increase in aortic stiffness with age in hypertensive subjects. J Hypertens. 2001;19:407-413.

20. Brand E, Chatelain N, Mulatero P, Fery I, Curnow K, Jeunemaitre X, Corvol P, Pascoe L, Soubrier F. Structural analysis and evaluation of the aldosterone synthase gene in hypertension. Hypertension. 1998;32:198204.

21. Brand E, Schorr U, Ringel J, Beige J, Distler A, Sharma AM. Aldosterone synthase gene (CYP11B2) C-344T polymorphism in Caucasians from the Berlin Salt-Sensitivity Trial (BeSST). J Hypertens. 1999;17:1563-1567.

22. Hengstenberg C, Holmer SR, Mayer B, Lowel H, Engel S, Hense HW, Riegger GAJ, Schunkert $\mathrm{H}$. Evaluation of the aldosterone synthase (CYP11B2) gene polymorphism in patients with myocardial infarction. Hypertension. 2000;35:704-709.

23. Schunkert H, Hengstenberg C, Holmer SR, Broeckel U, Luchner A, Muscholl MW, Kürzinger S, Döring A, Hense H-W, Riegger GAJ. Lack of association between a polymorphism of the aldosterone synthase gene and left ventricular structure. Circulation. 1999;99:2255-2260.

24. Paillard F, Chansel D, Brand E, Benetos A, Thomas F, Czekalski S, Ardaillou R, Soubrier F. Genotype-phenotype relationships for the reninangiotensin-aldosteron system in a normal population. Hypertension. 1999;34:423-429.

25. Melander A, Orho-Melander M, Bengtsson K, LIndblad U, Rastam L, Groop L, Hulthen UL. Genetic variants of thiazide-sensitive NaClcotransporter in Gitelman's syndrome and primary hypertension. Hypertension. 2000;36:389-394.

26. Corvol P, Persu A, Gimenez-roqueplo AP, Jeunemaitre X. Seven lessons from two candidate genes in human essential hypertension. Angiotensinogen and epithelial sodium channel. Hypertension. 1999;33:1324-1331.

27. Bianchi G, Tripodi G, Casari G, Salardi S, Barber BR, Garcia R, Leoni P, Torielli L, Cusi D, Ferrandi M, Pinna LA, Baralle FE, Ferrari P. Two point mutations within the adducin genes are involved in blood pressure variation. Proc Natl Acad Sci USA. 1994;91:3999-4003.

28. Bianchi G, Cusi D. $\alpha$-Adducin: is the glass half full or half empty? Am J Hypertens. 2000;13:739-743. 
29. Boerwinkle E. All for one and one for all: introduction to a coordinated analysis of the Gly-460-Trp $\alpha$-Adducin polymorphism. Am J Hypertens. 2000;13:734-735.

30. Morrison AC, Doris PA, Folsom AR, Javier Nieto F, Boerwinkle E, for the Atherosclerosis Risk in Communities Study. G-Protein $\beta 3$ subunit and $\alpha-$ adducin polymorphisms and risk of subclinical an clinical stroke. Stroke. 2001.

31. Benetos A, Gautier S, Ricard S, Topouchian J, Asmar R, Poirier O, Larosa E, Guize L, Safar ME, Soubrier F, Cambien F. Influence of angiotensin-converting enzyme and angiotensin II type 1 receptor gene polymorphisms on aortic stiffness in normotensive and hypertensive patients. Circulation. 1996;94:698-703.

32. Benetos A, Cambien F, Gautier S, Ricard S, Safar M, Laurent S, Lacolley $\mathrm{P}$, Poirier O, Topouchian J, Asmar R. Influence of the angiotensin II type 1 receptor gene polymorphism on the effects of perindopril and nitrendipine on arterial stiffness in hypertensive individuals. Hypertension. 1996;28:1081-1084.

33. Benetos A, Topouchian J, Ricard S, Gautier S, Bonnardeaux A, Asmar $\mathrm{R}$, Poirier O, Soubrier F, Safar ME, Cambien F. Influence of angiotensin II type 1 receptor polymorphism on aortic stiffness in never-treated hypertensive patients. Hypertension. 1995;26:44-47.

34. Taniwaki H, Kawagishi T, Emoto M, Shoji T, Hosoi M, Kogawa K, Nishizawa $Y$, Morii $H$. Association of ACE gene polymorphism with arterial stiffness in patients with type 2 diabetes. Diabetes Care. 1999;22:1858-1864.

35. Frankel WN, Schork NJ. Who's afraid of epistasis. Nat Genet. 1996;14:371-373.

36. Lifton RP. Genetic determinants of human hypertension. Proc Nat Acad Sci USA. 1995;92:8545-8551.

37. Delgado CM, Gleiberman L, Yang D, Chakravarti A, Weder AB. The 460Trp $\alpha$-adducin allele and high sodium-lithium countertransport are associated with high blood pressure and increased body fat. $A m \mathrm{~J}$ Hypertens. 2001;14:173A.

38. Gainer JV, Stein CM, Neal T, Vaughan DE, Brown NJ. Interactive effects of ethnicity and ACE insertion/deletion polymorphism on vascular reactivity. Hypertension. 2001;37:46-51.

39. O'Donnel CJ, Lindpaintner K, Larson MG, Rao VS, Ordovas JM, Schaefer EJ, Myers RH, Levy D. Evidence for association and genetic linkage of the angiotensin-converting enzyme locus with hypertension and blood pressure in men but not women in the Framingham heart study. Circulation. 1998;97:1766-1772.

40. Higaki J, Baba S, Katsuya T, Sato N, Ishikawa K, Mannami T, Ogata J, Ogihara T. Deletion allele of angiotensin-converting enzyme gene increases risk of essential hypertension in Japanese men: the Suita study. Circulation. 2000;101:2060-2065. 
41. Touyz RM, Schiffrin EL. Activation of the $\mathrm{Na}^{+}-\mathrm{H}^{+}$exchanger modulates angiotensin II stimulated $\mathrm{Na}^{+}$-dependent $\mathrm{Mg}^{2+}$ transport in vascular smooth muscle cells in genetic hypertension. Hypertension. 1999;34:442-449.

42. Blaustein MP. Sodium transport and hypertension; where are we going? Hypertension. 1984;6:445-453. 
Chapter 8

Summary 
This thesis reports on a population study, the FLEMENGHO study, the Flemish Study on Genes, Environment and Health Outcomes. In a previous sample of this population, vessel wall properties of the common carotid, femoral and brachial artery were investigated in relationship to known cardiovascular risk factors, such as hypertension, smoking, diabetes mellitus, insuline-resistance, body weight and age.

The present study investigated whether genetic background plays a role in large artery function and structure and systemic vascular resistance.

Chapter one provides a brief overview of the known relationship between large artery properties and traditional cardiovascular risk factors. Known monogenic forms of cardiovascular disease are presented, the knowledge of which is, next to the understanding of the regulation of blood pressure, one of the hallmarks of the search for candidate genes in the development of cardiovascular disease. An overview is given of the most commonly investigated candidate genes which may play a role in the origin of essential hypertension. Three gene variants, and the rationale for the choice of these three genes, are presented: the ACE $I / D$, the $\alpha$-adducin Gly460Trp and the aldosterone synthase $C$-344T polymorphism. In the FLEMENGHO study population these three polymorphisms are related to the incidence and prevalence of hypertension, as well as to renal function.

In chapter one we also describe systemic vascular resistance index, large artery compliance and distensibility, and intima-media thickness as intermediate phenotypes in relationship to possible candidate genes as described thus far in the literature.

Chapter two describes the study design and methods. Our study was part of the FLEMENGHO study. In a sample of 442 subjects, we investigated the polymorphisms of the ACE, $\alpha$-adducin and aldosterone synthase genes and their association with large artery properties and systemic vascular resistance index. Cardiovascular measurements were performed in a non-invasive manner. Large artery properties were assessed with applanation tonometry in combination with an ultrasound based wall track system. Cardiac output was assessed with echo-Doppler techniques.

Chapter three describes a new method for the assessment of local pulse pressure with the use of the vessel wall movement contour. This method showed good accuracy and could prove useful in those subjects in whom applanation tonometry is not applicable or inaccurate. Pulse pressure assessed with applanation tonometry (both absolute values and calibrated values) was compared to invasively detected pressure. Pulse pressure derived from the calibrated applanation tonometry was then compared to pulse pressure derived from the calibrated vessel wall movement contour. This study 
showed that pulse pressures assessed with applanation tonometry,when calibrated with mean and diastolic blood pressure, correlated very well with invasively measured pulse pressures $(r=0.92)$. Calibrated pulse pressures assessed with applanation tonometry were on average $1.8 \pm 5.2 \mathrm{mmHg}$ higher than invasively detected pulse pressure values. Calibrated pulse pressures assessed with vessel wall movement contours were on average $3.4 \pm 6.9$ $\mathrm{mmHg}$ lower than calibrated pulse pressure values assessed with applanation tonometry.

In chapter four the genetic influence on compliance and distensibility of the common carotid and femoral artery is presented. The combination of the ACE $I / D$ and $\alpha$-adducin Gly460Trp polymorphism had an effect at the muscular femoral artery, whereas the combination of the $A C E I / D$ and aldosterone synthase $C$-344T polymorphism had an effect at the common carotid artery. Our hypothesis was that the different composition of the wall of large arteries plays a role in the differential effect of these polymorphisms.

Chapter five describes the effect of three genes on systemic vascular resistance index and cardiac index. This study showed that the combination of the ACE I/D and $\alpha$-adducin Gly460Trp polymorphism may distinguish between volume-dependent and non-volume dependent hypertension. Our conclusion was based on the finding that ACE DD homozygotes, in the absence of the 460Trp allele for $\alpha$-adducin, had a higher systemic vascular resistance and a lower cardiac index. In these subjects vasoconstriction of the resistance arteries rather than chronic sodium retention and circulatory volume expansion may play a role in the pathogenesis of hypertension.

Intima-media thickness is regarded by many investigators as a risk factor for cardiovascular diseases like stroke and myocardial infarction. To investigate whether the three candidate genes had a influence on intima-media thickness, 380 , randomly selected subjects, were studied as presented in chapter six. The main finding of this study was that only in the muscular femoral artery, the intima-media thickness increased with the number of ACE $D$ alleles. This increase was only noted in those subjects who also carried the $\alpha$-adducin $460 T r p$ or aldosterone synthase $-344 T$ alleles. These findings suggest that these three polymorphisms act on a cellular level with a major role of their effect on sodium handling. Our study leaves the question unanswered whether the observed effect on femoral intima-media thickness represents an adaptive mechanism of the arterial wall to an increased circulating volume or a direct effect mediated by changes in the ion fluxes across the cell membrane of vascular smooth muscle cells.

Our findings on all three intermediate phenotypes are put in context in chapter seven. Our main rationale for investigating combination of genes instead of single genes is discussed. Furthermore our hypothesis on the action of the different combinations of polymorphisms at a cellular level is presented. Our 
main hypothesis is that the effect of all three genes on sodium channels or exchangers will increase intracellular sodium. This may lead to an increase in intracellular free calcium which in turn may explain the increased vascular tone and hypertrophy of vascular smooth muscle cells. Based on our present findings we believe that multiple genes are involved in the pathogenesis of socalled essential hypertension.

Laboratory experiments are necessary to elucidate the role of extracellular sodium and intracellular free calcium in vascular smooth muscle cells in explaining the observed structural and functional effects at the level of large arteries. Carriers of the risk conferring genotypes will also contribute to a better insight in the pathogenesis of cardiovascular risk. 


\section{Samenvatting}

Dit proefschrift beschrijft de resultaten van een bevolkingsstudie, de FLEMENGHO studie (Flemish Study on Genes, Environment and Health Outcomes). In een eerder onderzochte groep van deze populatie werden vaatwandeigenschappen (distensibiliteit en compliantie) van de slagaders in de hals, de lies en de arm bepaald met betrekking tot bekende risicofactoren voor hart- en vaatziekten, zoals hoge bloeddruk, roken, suikerziekte, insulineresistentie, overgewicht en leeftijd.

De huidige studie onderzocht of genetische achtergrond een rol speelt in de functie en structuur van grote slagaders en in de systemische vaatweerstand.

Hoofdstuk 1 beschrijft in een kort overzicht de relatie tussen vaatwandeigenschappen en traditionele risicofactoren voor hart- en vaatziekten.

Allereerst worden mutaties in één gen die hart- en vaatziekten veroorzaken besproken. Deze zogeheten monogenetische ziekten vormen een bron van kennis over de regulatie van bloeddruk; daarnaast zijn ze de speerpunten van de zoektocht naar kandidaat genen verantwoordelijk voor de ontwikkeling van hart- en vaatziekten.

De momenteel meest in de belangstelling staande kandidaat genen die mogelijk een rol spelen in het ontstaan van essentiële hypertensie worden daarna besproken.

Drie polymorfismen, het angiotensin converting enzyme $1 / D, \alpha$-adducin Gly460Trp en aldosterone synthase C-344T passeren de revue, alsmede de hypothese die ten grondslag lag aan de keuze voor deze drie genen. In de FLEMENGHO studie bleken de drie genen gerelateerd te zijn aan de incidentie en prevalentie van hypertensie en aan de nierfunctie. Verder bevat hoofdstuk 1 een beschrijving van systemische vaatweerstand, compliantie en distensibiliteit van de grote slagaders en intima-media dikte als intermediaire fenotypes in relatie tot mogelijke kandidaat genen, zoals tot op heden beschreven in de literatuur.

Hoofdstuk 2 beschrijft de studie opzet en methoden. De drie polymorfismen van het $A C E, \alpha$-adducin en aldosterone synthase gen werden bepaald in 442 personen en onderzocht in relatie tot vaatwandeigenschappen en systemische vasculaire weerstand. De hart- en vaatmetingen werden verricht op een nietinvasieve manier. De vaatwandeigenschappen werden bepaald met behulp van applanatie tonometrie in combinatie met een wall-track systeem gebaseerd op echografie. Het hartminuutvolume werd bepaald door middel van echo-Doppler technieken.

Hoofdstuk 3 beschrijft een nieuwe methode voor het bepalen van de lokale polsdruk met gebruikmaking van de contour van de beweging van de vaawand. Deze methode blijkt accuraat en zou van belang kunnen zijn voor die personen waarbij applanatie tonometrie niet uitvoerbaar is of 
onbetrouwbaar. De polsdrukken gemeten met de applanatie tonometer (zowel absolute als gecalibreerde waarden) werden vergeleken met de invasief gemeten drukken. Vervolgens werd de gecalibreerde polsdruk, gemeten met de applanatie tonometer, vergeleken met de op dezelfde wijze gecalibreerde polsdruk berekend met behulp van de contour van de vaatwandbeweging. Deze studie toonde aan dat de polsdruk verkregen met behulp van applanatie tonometrie, indien gecalibreerd met de diastole en gemiddelde druk, goed correleerde met de invasief verkregen polsdruk $(r=0.92)$. De gecalibreerde polsdrukken waren gemiddeld $1.8 \pm 5.2 \mathrm{mmHg}$ hoger dan de invasief gemeten polsdrukken. De gecalibreerde polsdrukken berekend aan de hand van de contour van de vaatwandbeweging waren gemiddeld $3.4 \pm 6.9 \mathrm{mmHg}$ lager dan de gecalibreerde polsdrukken verkregen met applanatie tonometrie.

In hoofdstuk 4 wordt de genetische invloed op de distensibiliteit en compliantie van de halsslagader en de liesslagader behandeld. De combinatie van het angiotensin converting enzyme polymorfisme en het $\alpha$-adducin polymorfisme bleek een effect te hebben op de musculaire liesslagader, terwijl de combinatie van het angiotensin converting enzyme polymorfisme en het aldosterone synthase polymorfisme een effect had op de elastische halsslagader. Onze hypothese op basis van deze resultaten was dat de verschillende opbouw van de vaatwand van de beide slagaders een rol speelt in het lokaal verschillende effect van deze polymorfismen.

Hoofdstuk 5 beschrijft het effect van de drie polymorfismen op systemische vasculaire weerstand index en hartminuutvolume index. Deze studie toonde aan dat de combinatie van het angiotensin converting enzyme polymorfisme en het $\alpha$-adducin polymorfisme een onderscheid zou kunnen maken tussen volume afhankelijke- en volume onafhankelijke hoge bloeddruk. Deze conclusie werd gebaseerd op het feit dat personen met het angiotensin converting enzyme $D D$ genotype waarbij het $\alpha$-adducin gemuteerde 460Trp allel ontbrak, een hogere systemische vasculaire weerstand index en een lagere hartminuutvolume index hadden. Bij deze personen zou het samentrekken van de weerstandsvaten een belangrijker rol kunnen spelen dan toename van het circulerend volume door chronische zoutretentie in het ontstaan van hoge bloeddruk.

Intima-media dikte wordt door vele onderzoekers gezien als een risicofactor voor hart - en vaatziekten zoals een hersen- of hartinfarct. Om te onderzoeken of de drie genen de intima-media dikte beïnvloeden werden 380 personen onderzocht en de resultaten van deze studie worden gepresenteerd in hoofdstuk 6 . Het belangrijkste resultaat van deze studie was dat alleen in de musculaire liesslagader, de intima-media dikte toenam met het aantal $D$ allelen van het angiotensin converting enzyme polymorfisme. Deze toename werd echter alleen gezien bij die personen die het gemuteerde $-344 T$ allel van het aldosterone synthase of het gemuteerde 460Trp allel van het $\alpha$-adducin gen hadden. Deze bevindingen suggereren dat de drie polymorfismen invloed 
uitoefenen op het celniveau met een overwegend effect op de zouthuishouding. Onze studie laat de vraag echter onbeantwoord of de toename van de intima-media dikte een aanpassingsfenomeen is op het toegenomen circulerend volume of dat het effect teweeg gebracht wordt door veranderingen in de ionstromen over de celmembraan van de gladde spiercellen.

Onze bevindingen aangaande de drie fenotypes worden in perspectief geplaatst in hoofdstuk 7. Onze belangrijkste beweegreden om met name combinaties van polymorfismen en niet enkele polymorfismen te bestuderen wordt besproken. Daarnaast wordt onze hypothese betreffende het effect op een cellulair niveau tengevolge van de combinaties van de drie polymorfismen toegelicht. Onze hypothese is dat het effect van alle drie de genen op de zouthuishouding zal leiden tot een verhoogd zoutgehalte in de cel. Dit kan leiden tot een toename van het vrije calciumgehalte in de cel, wat op zijn beurt de toegenomen vaatwandspanning en hypertrofie van de gladde spiercellen kan verklaren. Gebaseerd op deze bevindingen zijn wij van mening dat meerdere genen betrokken zijn in de pathogenese van de zogenaamde essentiële hoge bloeddruk.

Om de rol van de zouthuishouding en intracellulair calcium in gladde spiercellen te verhelderen zullen laboratoriumexperimenten nodig zijn. Hierdoor zouden de gevonden structurele en functionele effecten op grote slagaders mogelijk verklaard kunnen worden. Onderzoek van personen met de risicoverhogende allelen zal tevens bijdragen tot een beter inzicht in het ontstaan van hoge bloeddruk. 
Curriculum Vitae

Elisabeth J.M. Balkestein

10 oktober 1963

1976-1983

1983-1984

1985-1992

1992-1994

1994-1995

1995-1997

1997-2001

2001-
Geboren te Maastricht

Atheneum $\beta$, St. Maartenscollege te Maastricht

Directie-Secretaresse, Instituut 'de Thermen' te Heerlen

Studie Geneeskunde, Universiteit Maastricht, te Maastricht

Agnio kindercardiologie, Academisch Ziekenhuis Maastricht, te Maastricht

Agnio kindergeneeskunde, Academisch Ziekenhuis Maastricht, te Maastricht

Bedrijfsarts i.o., Netherlands School of Public Health, te Utrecht

Assistent in opleiding, Cardiovascular Research Institute Maastricht, te Maastricht

Agnio Stichting VZR Centra voor verpleging zorg en reactivering, te Heerlen 
Publications

Full papers

Balkestein EJ, Aggel van-Leijssen DP, Baak van MA, Struijker Boudier HA, Bortel van LM. The effect of weight loss with or without exercise training on large artery compliance in healthy obese men. Journal of Hypertension. 1999;17:1831-1835.

Balkestein EJ, Staessen JA, Wang JG, Heijden van der- Spek JJ, Bortel Van LM,

Barlassina C, Bianchi G, Brand E, Herrmann S-M, Struijker Boudier HA. Carotid and femoral artery stiffness in relation to three candidate genes in a white population. Hypertension. 2001;38:1190-1197.

Bortel Van LM, Balkestein EJ, Heijden van der-Spek JJ, Vanmolkot FH, Staessen JA, Kragten JA, Vredeveld JW, Safar ME, Struijker Boudier HA, Hoeks AP. Non-invasive assessment of local arterial pulse pressure: comparison of applanation tonometry and echo-tracking. Journal of Hypertension. 2001;19:1037-1044.

Bortel Van LM, Spek JJ, Balkestein EJ, Sardina M, Struijker Boudier HA. Is it possible to develop drugs that act more selectively on large arteries? Journal of Hypertension. 1999;17:701-705.

Balkestein EJ, Wang JG, Staessen JA, Barlassina C, Bianchi G, Birkenhäger WH, Brand E, Den Hond E, Fagard R, Herrmann SM, Bortel Van LM, StruijkerBoudier HA. Carotid and femoral intima-media thickness in relation to three candidate genes in a Caucasian Population. Provisionally accepted Journal of Hypertension

Balkestein EJ, Staessen JA, Wang JG, Bortel Van LM, Barlassina C, Bianchi G, Brand E, Herrmann SM, Struijker-Boudier HA. Modulation of the ACE genotype effect on systemic vascular resistance index by the $\alpha$-adducin polymorphism in the general population. Submitted 


\section{Abstracts}

Balkestein EJ, Wang JG, Staessen JA, Barlassina C, Bianchi G, Brand E, Herrmann SM, Den Hond E, Bortel Van LM, Struijker-Boudier HA. Systemic vascular resistance index in relation to three candidate genes in a Caucasian population. Hypertension. 2001;38 (4): 967

Balkestein EJ, Staessen JA, Wang JG, Barlassina C, Bianchi G, Bortel Van LM, Struijker-Boudier HA. Combined effects on vascular wall characteristics of the ACE I/D polymorphism and mutations of the $\alpha-\beta-\gamma$ adducin genes. Am J Hyper. 2001;14 (4 pt 2):123A-124A

Wang JG, Balkestein EJ, Staessen JA, Barlassina C, Bianchi G, Brand E, Den Hond E, Fagard R, Herrmann SM, Bortel Van LM, Struijker-Boudier HA. Singular and epistatic effects of three candidate genes on carotid and femoral intima-media thickness in a Caucasian population. Am J Hypertens. 2001;14 (4 pt 2): $121 \mathrm{~A}$

Balkestein EJ, Wang JG, Staessen JA, Barlassina C, Bianchi G, Brand E, Herrmann SM, Den Hond E, Fagard R, Birkenhäger WH, Bortel Van LM, Struijker-Boudier HA. Carotid and femoral intima-media thickness in relation to three candidate genes in a Caucasian population. $J$ Hypertens. 2001;19(suppl 2): S182

Balkestein EJ, Staessen JA, Struijker-Boudier HA, Bortel Van LM. Gender differences in arterial compliance in children. $J$ Hypertens. 2000;18 (suppl 2): S192

Balkestein EJ, Aggel van-Leijssen, Baak van MA, Saris WH, Struijker-Boudier HA, Bortel Van LM. The effect of weight loss with or without exercise training on large artery compliance in healthy obese men. J Hypertens. 1999;17 (suppl 3): 54 


\section{Dankwoord}

Het lijkt vaak of iedereen als eerste naar het dankwoord kijkt, zo heb ik de afgelopen jaren vaak gemerkt. Een vreemde zaak eigenlijk, want je mag hopen dat je de mensen die je dankbaar bent, dat hebt laten blijken in de afgelopen jaren. Ik hoop dat dan ook, maar zal toch niet nalaten om enkele mensen te noemen.

Allereerst mijn mede-aio's, zij die al aio-af zijn en zij die wilden dat ze er al vanaf waren...?

Mariëlle, Karin, Wendy, Marijke en Gwen, hun bedank ik vooral voor de gezelligheid. Verder alle niet-aio's voor hun hulp en steun zoals onder andere Fazzi, Jo, Rob (vooral vlak voor de eindstreep...) en Paul.

Om in Maastricht te blijven wil ik verder meer dan bedanken al diegenen die geholpen hebben met praktische zaken. De mensen van de technische dienst, Maurice en Leon met name, die er niet twijfelden dat stoornissen echt acuut verholpen moesten worden als ik het vroeg... Verder bedank ik Vincent, die meteen zei: 'ik kom eraan' zodra hij mijn naam hoorde en niet eens afwachtte wat het probleem was met de hoeveelste? computer die weer eens 'crash'-te. Els en Mia, jullie hebben niet alleen alle hulp geboden; met jullie heb ook menige lach en traan gedeeld.

Ook Arnold wil ik speciaal bedanken. Afgezien van het feit dat ik veel van je geleerd heb, waardeer ik de extra uren die je besteed hebt (nadat je al tegensputterend beweerde dat het helemáál niet uitkwam en je àllerlei plannen had voor het weekend of de avond en het écht wel even zou duren) aan de programmatuur van de 'vaatwand'-polsdrukken, die je dan meteen de dag erna aanleverde........

Dit onderzoek heeft alleen plaats kunnen vinden door de bereidwilligheid van vele proefpersonen. Ook hen wil ik nogmaals bedanken. Niet alleen de mensen van Hechtel-Eksel en omstreken, maar ook de 'mannen' die bij Dorien menig kilootje zijn afgevallen.

De proefschrift-titel, die de term 'polygenic' bevat, had ook 'poly-European' kunnen bevatten. Een samenwerking tussen vier landen, met de nadruk op de samenwerking tussen België en Nederland. In het eerste land zitten heel wat mensen die ik wil bedanken. Niet alleen de zogeheten veldwerkers, Alida, Lieve, Marie-Jeanne, Sylvia en Rina, maar ook de Leuvense collega's. Paul, ik ken niemand die zo relaxed kan zijn in de meest stressvolle situatie's. Ji-Guang, nobody knows more about statistics then you do, I learned a lot from you. For me a lot, for you probably the basics....; don't ask: why?

Alle andere collega's in Leuven: Elly, Lut, Lutgarde, Tim, Fan, Hilde, Renilde en Tanja: jullie hebben mij een hele fijne tijd in Leuven bezorgd. Ik werd net niet helemaal gek van SAS dankzij jullie! lk heb me echter vooral heel erg welkom gevoeld bij jullie en daar ben ik jullie het meest dankbaar voor! 
Afsluiten wil ik met de mensen te bedanken die ervoor gezorgd hebben dat ik uiteindelijk toch dit dankwoord kan schrijven. Het heeft er heel anders voorgestaan zoals zij weten.

Lieve Mam, bedankt voor alles!

Helma, je was er als ik het helemaal niet meer zag zitten. Je luisterend oor is goud waard geweest!

Beste Harry, Niet alleen heb ik oprechte bewondering voor je, als wetenschapper en als mens, ik ben je echt heel dankbaar. Je hebt je nek uitgestoken en me (zelf)vertrouwen geschonken.

Beste Jan, Je zegt zo vaak: 'we can make a difference!'

Rest me alleen te zeggen dat ik daar zeker van ben, maar dat jij dat voor mij al gedaan hebt.

Lieve Peter, Eens een coach, altijd een coach! Wij hebben gewonnen! 